Western Kentucky University TopSCHOLAR ${ }^{\circledast}$

$8-1-2003$

\title{
Investigation of the Relationship Between Particulate Bound Mercury and Properties of Fly Ash in a Full-Scale 100 MWE Pulverized Coal Combustion Boiler
}

Sen Li

Western Kentucky University

Follow this and additional works at: http://digitalcommons.wku.edu/theses

Part of the Chemistry Commons

\section{Recommended Citation}

Li, Sen, "Investigation of the Relationship Between Particulate Bound Mercury and Properties of Fly Ash in a Full-Scale 100 MWE Pulverized Coal Combustion Boiler" (2003). Masters Theses \& Specialist Projects. Paper 552.

http://digitalcommons.wku.edu/theses/552 


\title{
INVESTIGATION OF THE RELATIONSHIP BETWEEN PARTICULATE BOUND MERCURY AND PROPERTIES OF FLY ASH IN A FULL-SCALE $100 \mathrm{MW}_{\mathrm{E}}$ PULVERIZED COAL COMBUSTION BOILER
}

\author{
A Thesis Presented to \\ the Faculty of the Department of Chemistry \\ Western Kentucky University \\ Bowling Green, Kentucky
}

In Partial Fulfillment

of the Requirements for the Degree

Master of Science

by

Sen $\mathrm{Li}$

August 2003 
INVESTIGATION OF THE RELATIONSHIP BETWEEN ARTICULATE BOUND

MERCURY AND PROPERTIES OF FLY ASH IN A FULL-SCALE 100 MW E

PULVERIZED COAL COMBUSTION BOILER

Date Recommended August 7,2003
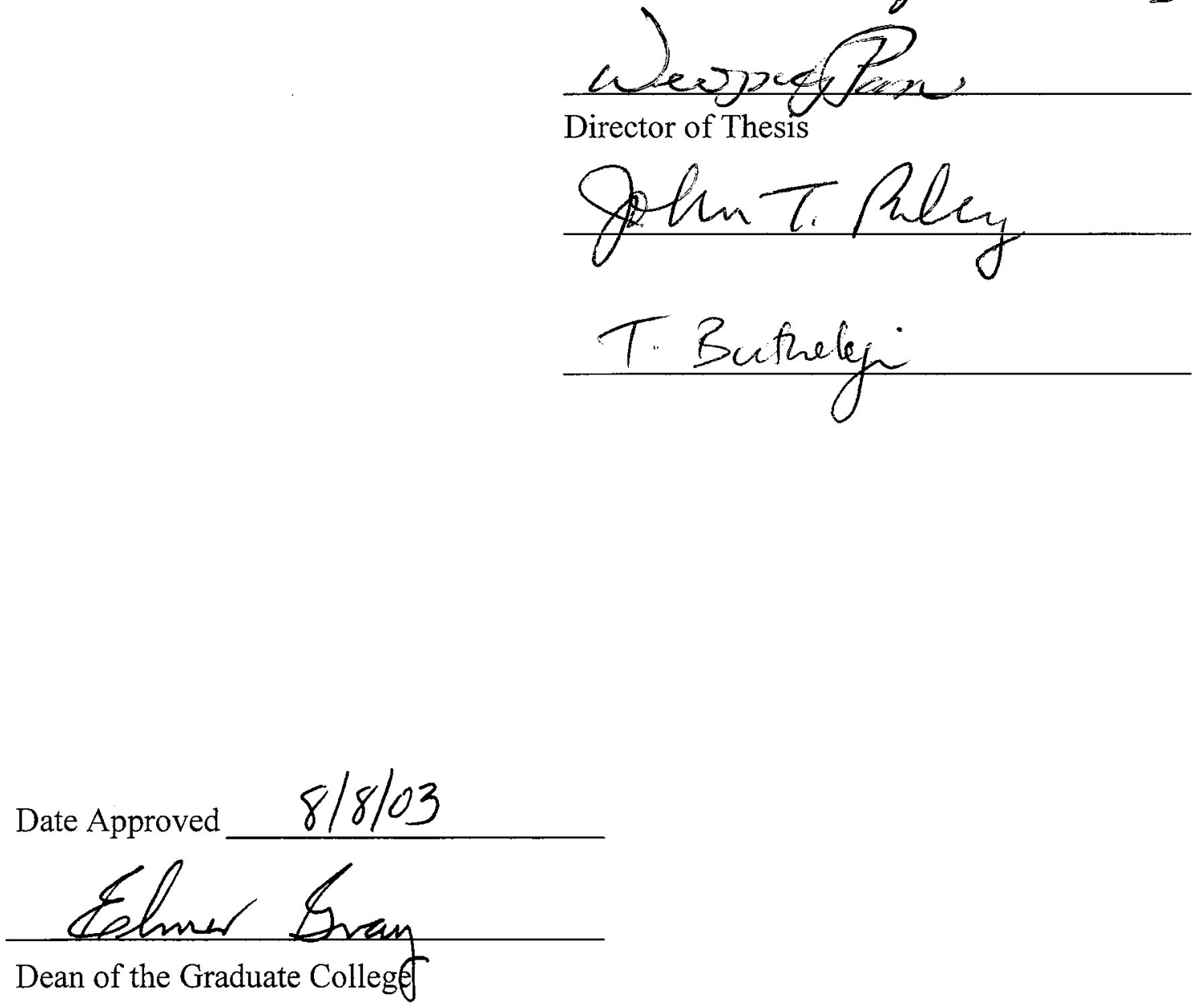


\section{ACKNOWLEDGEMENT}

I would like to express my deep appreciation to Dr. Wei-Ping Pan, my academic advisor and director of my thesis, for his instruction, encouragement and patience through the past two years. This work would not have been accomplished without his expertise, guidance and assistance. I also want to acknowledge Dr. John T. Riley, Dr. Thandi M. Buthelezi and Dr. Kunlei Liu for their wise and valuable suggestions. Additionally, I sincerely thank Dr. Yan Cao, Dr. Yufeng Duan, Dr. Weibing $\mathrm{Xu}, \mathrm{Mr}$. Dong Li and other researchers for their kind support during these two years. And also, I really appreciate the help from Quentin Lineberry, my best friend. For my memorable two-year study at Western Kentucky University, I wish to acknowledge my gratitude to all the faculty and staff members of the Department of Chemistry. I need to acknowledge the financial support for this study from Electric Power Research Institute (Project Number: EP-P6549/C3336). Finally, I wish to show my innermost acknowledgement to my parents, my brother's family, and my dearest wife. To all of the above, I appreciate what I got and what I did in two years. Without the assistance and guidance from all of you, this thesis would have been a mission impossible. 


\section{TABLE OF CONTENTS}

Chapter

Page

ACKNOWLEDGEMENT .........................................................

TABLE OF CONTENTS.....................................................

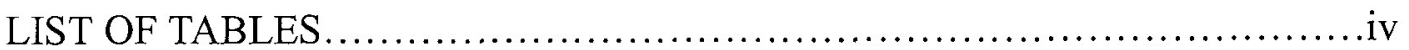

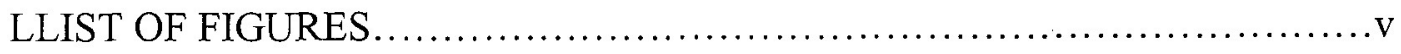

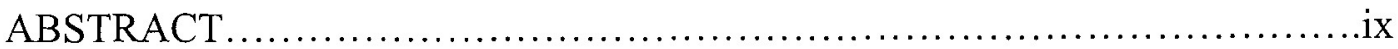

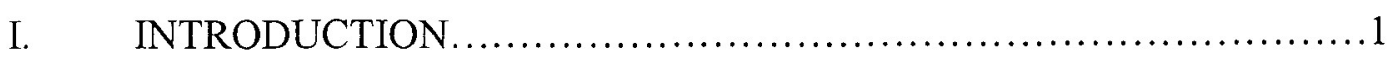

A. Background.........................................................

B. Mercury Speciation and Emission....................................

C. Research on the Effect of Fly Ash...................................6

D. Measurement of mercury ..............................................

E. Mercury Emission Control and Reduction Technologies.................11

F. Objective of This Study .........................................13

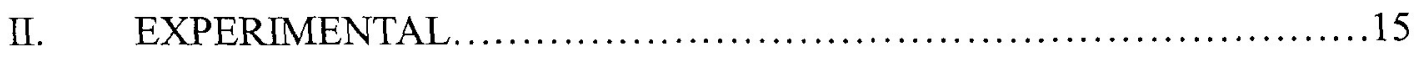

A. 100 MWe Low-NOx Burner Utility Boiler...........................15

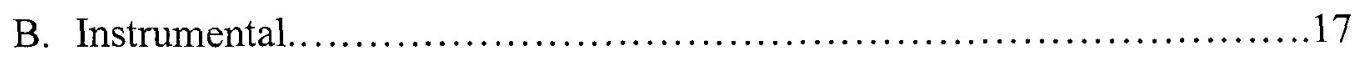

C. Coal Resources Studied...........................................20

D. Analysis Procedure for Solid Samples.................................20

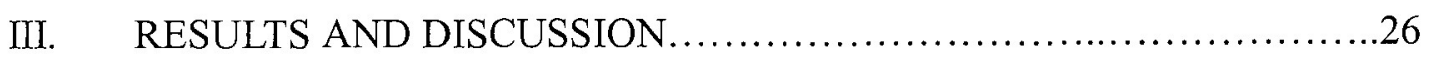

A. Mercury Removal and Particulate-bound Mercury ........................26

B. Unburned Carbon and LOI Regression.................................28

C. The Effect of Specific Surface Area.................................. 35 
D. Major, Minor Metal Oxides, and Others Element Regression Analysis....39

IV. CONCLUSIONS .................................................. 75

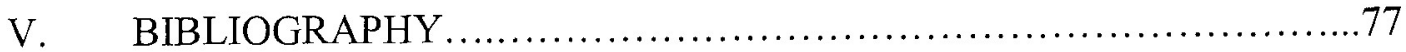




\section{LIST OF TABLES}

Tables

Pages

1. Configuration of Unit \#1 Boiler in the Power Plant ............................... 15

2. Average Results from Coal Sample Proximate and U1timate Analysis.......21

3. Concentrations of Major and Minor Element Oxides in Ashes

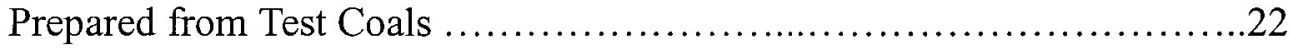

4. Average Analysis Results of Fly Ash from the MHP...........................27

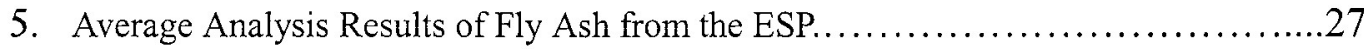

6. Regression Analysis of $\mathrm{Hg}^{\mathrm{p}}$-Carbon-LOI at the MHP and the ESP.................34

7. SSA Analysis Results for Ash at MHP ESP.............................. 38

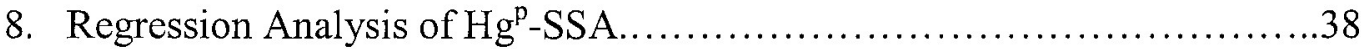

9. Regression Analysis for $\mathrm{Hg}^{\mathrm{p}}$-Metal Oxides at the MHP..................40

10. Regression Analysis for $\mathrm{Hg}^{\mathrm{p}}$-Metal Oxides at the ESP.....................54 


\section{LIST OF FIGURES}

$\underline{\text { Figures }}$

1. The configuration of the sampling 100 MWe Low-NOx burner utility boiler.

2. Regression plot of particulate mercury concentration vs. unburned carbon concentration in fly ash collected from the mechanical hopper.

3. Regression plot of particulate mercury concentration vs. unburned carbon concentration in fly ash collected from the electrostatic precipitator....30

4. Regression plot of particulate mercury concentration vs. LOI in fly ash collected from the mechanical hopper.

5. Regression plot of particulate mercury concentration vs. LOI in fly ash collected from the electrostatic precipitator.

6. Regression plot of particulate mercury concentration vs. SSA of fly ash collected from the mechanical hopper.

7. Regression plot of particulate mercury concentration vs. SSA of fly ash collected from the electrostatic precipitator.

8. Regression plot of particulate mercury concentration vs. $\mathrm{Na}_{2} \mathrm{O}$ concentration in fly ash collected from the mechanical hopper.

9. Regression plot of particulate mercury concentration vs. $\mathrm{MgO}$ concentration in fly ash collected from the mechanical hopper

10. Regression plot of particulate mercury concentration vs. $\mathrm{Al}_{2} \mathrm{O}_{3}$ concentration in fly ash collected from the mechanical hopper. .43 
11. Regression plot of particulate mercury concentration vs. $\mathrm{SiO}_{2}$ concentration in fly ash collected from the mechanical hopper

12. Regression plot of particulate mercury concentration vs. $\mathrm{CaO}$ concentration in fly ash collected from the mechanical hopper.

13. Regression plot of particulate mercury concentration vs. $\mathrm{K}_{2} \mathrm{O}$ concentration in fly ash collected from the mechanical hopper 46

14. Regression plot of particulate mercury concentration vs. $\mathrm{SO}_{3}$ concentration in fly ash collected from the mechanical hopper

15. Regression plot of particulate mercury concentration vs. $\mathrm{P}_{2} \mathrm{O}_{5}$ concentration in fly ash collected from the mechanical hopper.

16. Regression plot of particulate mercury concentration vs. $\mathrm{BaO}$ concentration in fly ash collected from the mechanical hopper

17. Regression plot of particulate mercury concentration vs. SrO concentration in fly ash collected from the mechanical hopper

18. Regression plot of particulate mercury concentration vs. $\mathrm{Fe}_{2} \mathrm{O}_{3}$ concentration in fly ash collected from the mechanical hopper

19. Regression plot of particulate mercury concentration vs. $\mathrm{MnO}_{2}$ concentration in fly ash collected from the mechanical hopper.

20. Regression plot of particulate mercury concentration vs. $\mathrm{TiO}_{2}$ concentration in fly ash collected from the mechanical hopper.

21. Regression plot of particulate mercury concentration vs. $\mathrm{Na}_{2} \mathrm{O}$ concentration in fly ash collected from the electrostatic precipitator 55

22. Regression plot of particulate mercury concentration vs. $\mathrm{MgO}$ concentration in fly ash collected from the electrostatic precipitator 
23. Regression plot of particulate mercury concentration vs. $\mathrm{Al}_{2} \mathrm{O}_{3}$ concentration in fly ash collected from the electrostatic precipitator.

24. Regression plot of particulate mercury concentration vs. $\mathrm{SiO}_{2}$ concentration in fly ash collected from the electrostatic precipitator.

25. Regression plot of particulate mercury concentration vs. $\mathrm{CaO}$ concentration in fly ash collected from the electrostatic precipitator.

26. Regression plot of particulate mercury concentration vs. $\mathrm{K}_{2} \mathrm{O}$ concentration in fly ash collected from the electrostatic precipitator

27. Regression plot of particulate mercury concentration vs. $\mathrm{SO}_{3}$ concentration in fly ash collected from the electrostatic precipitator

28. Regression plot of particulate mercury concentration vs. $\mathrm{P}_{2} \mathrm{O}_{5}$ concentration in fly ash collected from the electrostatic precipitator

29. Regression plot of particulate mercury concentration vs. $\mathrm{BaO}$ concentration in fly ash collected from the electrostatic precipitator.

30. Regression plot of particulate mercury concentration vs. SrO concentration in fly ash collected from the electrostatic precipitator.

31. Regression plot of particulate mercury concentration vs. $\mathrm{Fe}_{2} \mathrm{O}_{3}$ concentration in fly ash collected from the electrostatic precipitator.

32. Regression plot of particulate mercury concentration vs. $\mathrm{MnO}_{2}$ concentration in fly ash collected from the electrostatic precipitator.

33. Regression plot of particulate mercury concentration vs. $\mathrm{TiO}_{2}$ concentration in fly ash collected from the electrostatic precipitator

34. Regression plot of particulate mercury concentration vs. sulfur concentration in fly ash collected from the mechanical hopper. .68 
35. Regression plot of particulate mercury concentration vs. chlorine concentration in fly ash collected from the mechanical hopper................69

36. Regression plot of particulate mercury concentration vs. $\mathrm{S} / \mathrm{C} 1^{*} 10^{4}$ in fly ash collected from the mechanical hopper...................70

37. Regression plot of particulate mercury concentration vs. sulfur concentration in fly ash collected from the electrostatic precipitator.............71

38. Regression plot of particulate mercury concentration vs. chlorine concentration in fly ash collected from the electrostatic precipitator.............72

39. Regression plot of particulate mercury concentration vs. $\mathrm{S} / \mathrm{C} 1^{*} 10^{4}$ in fly ash collected from the electrostatic precipitator................73 
INVESTIGATION OF THE RELATIONSHIP BETWEEN PARTICULATE BOUND MERCURY AND PROPERTIES OF FLY ASH IN A FULL-SCALE 100MW PULVERIZED COAL COMBUSTION BOILER

Sen Li

August 2003

79 Pages

Directed by: Dr. Wei-Ping Pan, Dr. John T. Riley and Dr. Thandi M. Buthelezi Department of Chemistry

Western Kentucky University

There is an increasing concern over mercury emissions from coal-fired boilers. Coal-fired power generation accounts for approximately $33 \%$ of total mercury emission in the United States. Once it is emitted into the atmosphere and deposited on land or water, mercury can transform into methylmercury, an organic form. Mercury can then enter the food chain, which poses a potential threat to human health and the environment. To study the relationship between particulate bound mercury and fly ash properties, fly ash samples were collected from the mechanical hopper (MHP) and the electrostatic precipitator (ESP) of a 100 MWe pulverized coal-fired boiler and analyzed for particulate mercury concentration $\left(\mathrm{Hg}^{\mathrm{p}}\right)$, unburned carbon, loss on ignition (LOI), elemental content and specific surface area (SSA). Different types of software, such as Microsoft Excel, Minitab and Origin, were applied to build the regression models to evaluate the relationship between $\mathrm{Hg}^{\mathrm{p}}$ and fly ash properties. The results of the analysis indicate that the amount of mercury emissions is dependent on the properties of the fly ash at the MHP and ESP as well as the amount of fly ash removed by air pollution control devices (APCD). 
Their relationship can be described as:

$\mathrm{Hg}^{\mathrm{p}}(\mathrm{MHP}), \mathrm{ppm}=0.0230+0.00838$ Carbon $(\mathrm{MHP}), \%+0.00385$ LOI $(\mathrm{MHP}), \%$

$\mathrm{Hg}^{\mathrm{p}}$ (ESP), ppm $=-0.0180+0.0670$ Carbon (ESP), \% 0.0448 LOI (ESP), \%

The SSA of ESP ash is larger than MHP ash, which can help explain why $\mathrm{Hg}^{p}$ at the ESP is higher than at the MHP. For the multiple metal oxides in fly ash, all the regression results indicate the trace elements have a very weak relationship with $\mathrm{Hg}^{\mathrm{p}}$. There is no significant effect from trace elements on mercury absorption.

Further study of $\mathrm{Hg}^{\mathrm{p}}$ catalyst mechanism and absorption phenomenon is ongoing. The function of various emission control technologies such as SCR and hot-side ESP in some coal-fired power plants are being evaluated. 


\section{INTRODUCTION}

\section{A. Background}

Electric power generation is predominant in our daily life. Coal-fired power plants are the primary type of power generation in the United States. Approximately 56 percent of the electric power is generated by coal-fired power plants. ${ }^{1}$ Coal consumption at electric utilities has increased constantly since 1991 with the largest increases occurring in the past few years. In 1997, coal consumption was 900 million tons, 25 million tons more than in $1996 .^{2}$ Abundant American coal resources will continue to provide low cost and reliable electricity for decades into the future.

Undoubtedly, the coal industry has been playing a key role not only in the power generation area but also in the expanding and developing $21^{\text {st }}$ century economy. As the U.S. electric power industry faces a new and competitive business structure, more advanced technologies are required to increase the efficiency, lower the emissions and improve the economics and overall performance of coal-fired electric power plants. ${ }^{3}$ It is believed that, in the future, there will be a new class of fuel-flexible facilities that can produce electric power, process heat, and the chemicals, yet will be capable of emitting virtually no noxious, sulfuric, or other pollutants regulated by the EPA. 
Coal combustion processes may result in the emission of many hazardous air pollutants (HAP) such as mercury $(\mathrm{Hg})$ as well as criteria pollutants such as $\mathrm{NO}_{\mathrm{x}}$ and $\mathrm{SO}_{\mathrm{x}}$. The actual emissions are 11.2 million tons $\mathrm{SO}_{\mathrm{x}}, 5.1$ million tons $\mathrm{NO}_{\mathrm{x}}$, and 48 tons mercury in $2000 .{ }^{3}$ Currently, mercury emissions from coal-fired power plants are the major source of mercury pollution in the United States. Four specific source categories account for approximately 80 percent of the total nationwide anthropogenic emissions: coal-fired electric utility boilers (33 percent), municipal waste combustors (19 percent), industrial and commercial boilers (18 percent), and medical waste incinerators (10 percent). It is estimated that other 10 percent of the $\mathrm{Hg}$ emissions are generated by manufacturing sources that use $\mathrm{Hg}$ as a processing agent, product ingredient, or where $\mathrm{Hg}$ is present as a trace constituent in a process raw material. ${ }^{1}$

Mercury is a metallic element that can be released into the atmosphere from both anthropogenic (i.e., made by humans) and natural sources. Ambient $\mathrm{Hg}$ concentrations in the air are typically very low. Human exposure by direct inhalation of $\mathrm{Hg}$ in the air is not the predominant public health concern at current levels. However, mercury emissions from coal-fired plants can be deposited on land surfaces or directly into rivers, lakes and oceans. Once deposited, the inorganic mercury is transformed by biological processes into a highly toxic form of organic $\mathrm{Hg}$ (methylmercury [MeHg]) that concentrates in fish and other organisms living in waters. A study by the National Academy of Sciences (NAS) concluded that human exposure to $\mathrm{MeHg}$ from eating contaminated fish and seafood is associated with adverse health effects related to neurological and developmental damage varying in severity depending on the $\mathrm{Hg}$ concentrations in the ingested food. ${ }^{4}$ An extreme example of these health effects cited by this study is the highdosage exposure from the consumption of MeHg-contaminated fish by the residents 
living near Minamata Bay in Japan in the 1950s that resulted in fatalities and severe neurological damage. ${ }^{5}$

Due to the harmful effects of mercury through the food-chain, the concern to control mercury emission from coal-fired power plants has been increasing recently. The U. S. Environmental Protection Agency (EPA), Department of Energy (DOE), the Electric Power Research Institute (EPRI) and other organizations have been supporting research work on mercury measurement and reduction technologies for the past decade. EPA has decided to regulate HAP emissions from coal-fired power plants. The draft proposal of regulations will be published in December 2003 and put into practice by December $2004 .^{6}$

President Bush proposed the "Clear Skies Initiative" on February 14, 2002, and Senator Jeffords Proposed the "Clean Power Act of 2002" in late July 2002. These Initiatives request a reduction of mercury emissions from 48 tons to 26 tons by the year 2010, with a 15 ton cap in 2018. ${ }^{7}$ Continuous Emissions Monitoring (CEM), a mercury measurement technology, was highlighted in the proposal. Utilities and power plants are required to install mercury control technologies and other pollution control equipment. The proposal Clear Skies Initiative reveals the impossibility of achieve significant mercury emission reduction in such a short time frame by utilizing activated carbon and fabric filters as control technologies. It is very important to characterize and determine facility and/or fuel-type absolute emissions, understand the behavior of $\mathrm{Hg}$ in combustion processes and configurations, and to evaluate the removing efficiency of control technologies for mercury in coal-fired power plants. 


\section{B. Mercury Speciation and Emission}

The mercury concentration in coal is very low, approximately $0.1 \mathrm{ppm} .{ }^{8}$ When coal is burned in an electric utility boiler or a furnace, all mercury bound in the coal is released into the vapor phase during the high temperature combustion process as gaseous elemental mercury $\left(\mathrm{Hg}^{0}\right)$. Subsequent cooling of the combustion gases and interaction of the gaseous $\mathrm{Hg}^{0}$ with other combustion products result in a portion of the $\mathrm{Hg}^{0}$ being converted to gaseous oxidized forms of mercury $\left(\mathrm{Hg}^{2+}\right)$, and particle-bound mercury $\left(\mathrm{Hg}^{\mathrm{p}}\right)$.

Elemental mercury $\left(\mathrm{Hg}^{0}\right)$, oxidized mercury $\left(\mathrm{Hg}^{2+}\right)$ and particle-bound mercury $\left(\mathrm{Hg}^{\mathrm{p}}\right)$ are three different kinds of mercury in the flue gas produced from coal combustion and their sum is called total mercury $\left(\mathrm{Hg}^{\mathrm{T}}\right)$. Each form of mercury has a very different exposure potential. Oxidized mercury is soluble and has a tendency to associate with particulate matter. Therefore, emissions of oxidized mercury may be efficiently controlled by an air pollution control device (APCD) such as a flue gas desulfurization (FGD) system or a particulate precipitator or sorbent injection. On the other hand, elemental mercury is extremely volatile and insoluble. Elemental mercury has a high vapor pressure at typical APCD's operating temperatures. Therefore, effective collection by particulate matter control devices is highly variable. Also, elemental mercury is not captured by FGD and any kind of APCD systems. While some chemically treated activated carbons or selective absorbents may remove elemental mercury, they are more difficult to collect and treat. Therefore, elemental mercury emissions are more difficult to reduce than oxidized mercury emissions. ${ }^{9}$

Studies also indicate that the distribution of $\mathrm{Hg}$ species in the flue gas in coalfired boilers is strongly dependent on the type of coal (e.g., bituminous, subbituminous, 
or lignite), the operating conditions of the combustion system (in terms of unburned carbon in the ash), and temperature and residence time in the particulate control device. ${ }^{6}$ It was observed that higher concentrations of ionic mercury are obtained in utility flue gas when the combusted coal has a high chloride content ( 0.1 to 0.3 weight percent). Additional studies, including those conducted at Western Kentucky University, have suggested that Ca may play a role in mercury speciation. ${ }^{10,11}$ Furthermore, other components of the air pollutant control systems such as FGD and SCR systems have also been shown to affect the speciation of mercury in the stack.

Recent experiments ${ }^{2}$ suggest that mercury oxidation occurs at temperatures above the point where equilibrium predicts only elemental mercury will exist. Examination of possible elementary reactions indicates that only reactions with chlorine are fast enough to account for the oxidation. Attempts have been made to use thermochemical equilibrium calculations to predict the mercury speciation in coal combustion flue gas. ${ }^{6}$ The relationship between mercury speciation and temperature is summarized below:

1. Above about $975 \mathrm{~K}\left(700^{\circ} \mathrm{C}\right), 99 \%$ of the $\mathrm{Hg}$ is predicted to exist as gaseous $\mathrm{Hg}$, and the remaining $1 \%$ is predicted to be gaseous mercuric oxide $(\mathrm{HgO})$.

2. Below $725 \mathrm{~K}\left(450^{\circ} \mathrm{C}\right)$, all $\mathrm{Hg}$ is predicted to exist as mercuric chloride $\left(\mathrm{HgCl}_{2}\right)$.

3. Between 725 and $975 \mathrm{~K}$, the split between $\mathrm{HgCl}_{2}$ and $\mathrm{Hg}^{0}$ is determined by the chlorine content of the coal, via the hydrogen chloride $(\mathrm{HCl})$ content of the flue gas. ${ }^{6}$

Even at the lowest concentrations, the reaction between $\mathrm{Hg}$ and $\mathrm{HCl}$ dominates the equilibrium chemistry. In accordance with the thermochemical equilibrium calculations, at the temperature range of the inlet of the APCD, all of the Hg should exist in the gas phase as $\mathrm{HgCl}_{2}$, if equilibrium is attained in the flue gas. However, that is not the case, and there are strong arguments against the existence of chemical equilibrium in 
the flue gas of a coal-fired power plant. The flue gas cools rapidly as heat is transferred to water and steam; typical cooling rates are on the order of $500 \mathrm{~K} / \mathrm{sec}$. Minor species in the flue gas, such as carbon, $\mathrm{NO}_{\mathrm{x}}, \mathrm{CO}$ and sulfur dioxide $\left(\mathrm{SO}_{2}\right)$, do not have time to equilibrate as the gas cools. Kinetic calculations also indicate that the conversion of another trace species, $\mathrm{HCl}$ to $\mathrm{Cl}_{2}$, is quenched as the flue gas cools. ${ }^{12}$ Studies to determine the mechanisms involved with $\mathrm{Hg}$ speciation during combustion and the rapid transition to post-combustion conditions while firing different ranks of coal are continuing.

\section{Research on the Effect of Fly Ash}

Gaseous $\mathrm{Hg}$ (both $\mathrm{Hg}^{0}$ and $\mathrm{Hg}^{2+}$ ) in the flue gas can be adsorbed by the solid particles in the coal-fired electric boiler. The vapor molecules in a gas stream contact the surface of a solid particle and are held there by attractive forces between the vapor molecules and the solid. Solid particles are present in all coal-fired electric utility boiler flue gas as a result of the ash that is generated during combustion of the coal. Ash that exits the furnace with the flue gas is called fly ash. Gaseous $\mathrm{Hg}$ can be adsorbed by fly ash in the flue gas via "in-flight" adsorption. In-flight adsorption of gaseous $\mathrm{Hg}$ by fly ash occurs in the post-combustion region where the flue gas contains its highest concentration of fly ash. Coal fly ash is a mixture of metal oxides found in both crystalline and amorphous forms. Glasses are common ash constituents, composed primarily of the oxides of silicon and aluminum that can contain a significant amount of cations such as iron, calcium, and magnesium as well as certain amounts of sodium, potassium, copper, etc. ${ }^{13,14}$ In the presence of sufficiently high flue-gas concentrations of $\mathrm{HCl}$ or $\mathrm{Cl}_{2}$, metallic oxides in fly ash may be converted to metal chlorides such as cuprous chloride $(\mathrm{CuCl}){ }^{15}$ 
A study of the role of fly ash in the speciation of $\mathrm{Hg}$ in coal combustion flue gases was reported by Iowa State University. ${ }^{16}$ In this study, bench-scale laboratory tests were performed in a simulated flue gas stream using two fly ash samples obtained from the ESPs of two full scale coal-fired electric utility boilers. It was observed that, although the fly ashes tested were chemically and mineralogically different, there were no significant differences in the catalytic potential for oxidizing $\mathrm{Hg}^{0}$. The study also indicates that other factors will affect the particulate-bound mercury in fly ash.

\section{Measurement of Mercury}

In order to control mercury emission from power plants, accurate measurements of $\mathrm{Hg}$ speciation in the flue gas are important. Currently, a variety of measurement techniques, both manual and continuous monitoring, are available for measuring total $\mathrm{Hg}$ and its speciation forms. Because of the importance of these measurements, particularly speciated $\mathrm{Hg}$ measurements, research on $\mathrm{Hg}$ measurement techniques and performance is an integral component of the overall $\mathrm{Hg}$ control research strategy. The science of speciated $\mathrm{Hg}$ measurements from coal-fired electric utility boilers has only recently been investigated, with the majority of research on the subject occurring within the last 5 years. $^{17}$

\section{Ontario-Hydro Method (OHM)}

Ontario-Hydro Method 1 is a manual method for determining total mercury concentration in a coal-fired power plant. ${ }^{18}$ Generally, the sampling train consists of the following sampling components: a nozzle and glass liner operated isokinetically for extracting a representative sample from the stack or duct, a filter to collect particulate matter, and a set of impingers containing reagent to capture gas-phase $\mathrm{Hg}$, a meter and a 
vacuum pump. For this method, the oxidized mercury $\left(\mathrm{Hg}^{2+}\right)$ in a flue gas sample is absorbed by $\mathrm{KCl}$ solution in first three impingers, the elemental mercury $\left(\mathrm{Hg}^{0}\right)$ is oxidized and trapped by $\mathrm{HNO}_{3}$ and $\mathrm{KMnO}_{4}$ solution in the following impingers. $\mathrm{H}_{2} \mathrm{O}_{2}$ is used as a conditioner to control $\mathrm{SO}_{2}$ concentration in the flue gas. After sampling, the filter and sorption media are recovered and analyzed for $\mathrm{Hg}$ using cold-vapor atomic absorption or fluorescence spectrometry.

Bias will possibly exist in this method because the fly ash captured by the filter may absorb or catalyze the mercury in flue gas when it passes through the filter, however, the total mercury in the flue gas, including oxidized mercury, elemental mercury and particle-bound mercury can be evaluated accurately.

Although the $\mathrm{OH}$ Method is the most thoroughly examined and accepted method and meets EPA Method 301 validation requirements, application to air pollution control device inlet locations should be considered with caution due to the known catalytic and absorptive effects of certain coal fly ash particulate matter. These measurement factors do not affect the use of the $\mathrm{OH}$ Method for total $\mathrm{Hg}$ measurements. ${ }^{19}$

\section{Continuous Emission Monitors (CEMs)}

Continuous Emission Monitors (CEM) methods are capable of providing a realtime or near-real-time responses for $\mathrm{Hg}$ emissions in coal-fired boilers. ${ }^{20} \mathrm{~A}$ CEM can be used to obtain continuous $\mathrm{Hg}$ measurements for a long period of time. Conversely, manual methods such as $\mathrm{OHM}$ are capable of only infrequent "snapshot" $\mathrm{Hg}$ measurements in a short period. As a result, a CEM system can distinguish the magnitude and duration of short-term emission characteristics as well as perform long-term emission measurements to truly characterize a process's temporal emissions. Again, manual methods are not capable of performing these functions. The CEM method is a valuable 
and powerful tool supporting the measurement and control of $\mathrm{Hg}$ emissions from coalfired electric power plants.

The other advantage of a CEM system is its capability to measure the gaseous mercury using several streams together. Western Kentucky University performed some introductory research work on mercury emission using a semi-continuous emissions monitor (SCEM). The SCEM used in the study is the Sir Galahad II manufactured by PS Analytical Ltd. It uses a gold trap to collect the mercury from the flue gas before analysis with an atomic fluorescence detector. ${ }^{20}$

Without the aid of a pretreatment system, the Sir Galahad is unable to speciate mercury. The pretreatment system, Model S235C400 manufactured by Baldwin, splits the incoming flue gas into two streams. One stream passes through a $\mathrm{KCl}$ solution, which traps oxidized mercury, thereby allowing only elemental mercury to reach the detector. The other stream passes through a stannous chloride solution, which reduces oxidized mercury to $\mathrm{Hg}^{0}$, thus facilitating the measurement of total mercury. Both solutions also serve the dual purpose of removing acidic gases that could damage the gold detector. In general, the application of this CEM is limited in the research field because it uses wet chemistry techniques and requires a technician to monitor, as well as measure the gaseous mercury species.

The combination of the Ontario Hydro Method and Continuous Emission Monitoring Method provides a complete, complementary and more accurate technology of mercury measurement.

\section{Particle-Bound Mercury $\left(\mathrm{Hg}^{\mathrm{p}}\right)$ measurement}

Mercury bound in fly ash is normally measured by cold vapor atomic absorption spectrometry (CVAAS). ${ }^{21}$ With the recent approved method D6722 by ASTM, the AMA 
254 mercury analyzer made by LECO offers a fast and cost-effective alternative to conventional CVAAS for the measurement of mercury in raw coal or ash samples by thermal decomposition, amalgamation and atomic absorption spectrometry. Without sample pretreatment or sample pre-concentration, the total mercury in solid or liquid samples can be analyzed in three phases: decomposition, collection and detection. The sample in a combustion tube is heated to about $750^{\circ} \mathrm{C}$ to a gaseous form in an oxygen carrier gas. The pre-packed specific catalytic compounds in the combustion tube remove all interfering impurities in the evolved gases such as ash, moisture, halogens and minerals. After the decomposition, the amalgamator, a small glass tube containing goldplated ceramics, will collect all the mercury in the cleaned, evolved gases. The temperature of collection is significantly lower than the decomposition phase with the high affinity for mercury; all the mercury in the vapor phase can then be released to the detection system by heating the amalgamator to $900^{\circ} \mathrm{C}$. During the detection phase, all vapors pass through two sections of a cuvette that is located in the path length of a standard atomic absorption spectrometer. The dual-path cuvette expands the dynamic range from the sub-ppb level to upper ppm level. The spectrometer uses an elementspecific lamp that emits light at a wavelength of $253.7 \mathrm{~nm}$ that is specific to elemental mercury and will be absorbed by the mercury particles in the vapor for subsequent detection by a silicon UV detector. The mercury concentration in the vapor evolved from fly ash can be determined by integrating the area associated with the total mercury signal versus time using the computer control system and Quicksilver software. 


\section{E. Mercury Emission Control and Reduction Technologies}

Mercury emission from coal-fired electric utility boilers can be controlled and reduced by pre-combustion controls, combustion controls and post-combustion controls. ${ }^{3}$ The raw coal often is first washed at a coal preparation plant to remove non-coal impurities before shipping to the coal-fired power plant. These processes commonly are collectively referred to as "coal cleaning." Depending on the properties of the coal and the type of process used, the $\mathrm{Hg}$ content of the coal ultimately fired in the electric utility boiler can be reduced. Physical coal cleaning typically involves a series of process steps including 1) size reduction and screening, 2) gravity separation of coal from sulfurbearing mineral impurities, and 3) dewatering and drying. ${ }^{22-23}$ Limited data have been gathered on the level of Hg removed by conventional coal cleaning methods. Currently, it is reported the range of mercury reduction by coal cleaning is from 12 to 78 percent. $^{22}$

For post-combustion controls, one or more air pollution control devices are applied at a point downstream of the boiler combustion zone to remove the pollutants including particulate matter containing mercury, $\mathrm{SO}_{2}$ and $\mathrm{NO}_{\mathrm{x}}$, etc. Operational parameters and equipment can be modified to reduce mercury emissions, or materials such as sorbents can be injected into the combustion unit along with the fuel to capture the mercury before the combustion gases exit the boiler. In some research, mercury can be captured and removed from a flue gas stream by injecting a sorbent into the exhaust stream with subsequent collection in a particulate matter (PM) control device such as an

Electrostatic Precipitator (ESP) or a Fabric Filter (FF). ${ }^{23-25}$ However, the sorbent absorptive behavior for $\mathrm{Hg}$ from flue gas is very complex and varied because of the influence of the temperature, the composition of the flue gas, the concentration of $\mathrm{Hg}$ in the exhaust stream, and the physical and chemical characteristics of the sorbent and 
associated functional groups. The implementation of an effective and efficient $\mathrm{Hg}$ control strategy using sorbent injection requires the development of low-cost and efficient $\mathrm{Hg}$ or multipollutant sorbents. Of the known $\mathrm{Hg}$ sorbents, activated carbons and calcium-based sorbents have been the most actively studied. Western Kentucky University carried out research work on mercury capture efficiency by sorbent in a coal-fired heat plant and the result from CEM measurements is approximately $60-70 \%$ reduction of mercury emission.

There are four types of particulate matter (PM) emission control devices, electrostatic precipitator (ESP), fabric filters (FF), particle scrubbers (PS) and mechanical collectors (MC) that can collect the particulate matter containing particulate-bound mercury. Of these PM controls, electrostatic precipitators are the predominant control type used on coal-fired boiler units ( 83 percent), and the second most common control device is fabric filter (14 percent). For the $\mathrm{SO}_{2}$ and $\mathrm{NO}_{\mathrm{x}}$ emission control, wet flue gas desulfurization (FGD) systems (15 percent), spray dryer absorber (SDA) systems (5 percent), and selective catalytic or non-selective catalytic reduction (NSCR or SCR) (less than 4 percent) on coal-fired electric utility boilers are becoming prevalent. These types of PM control devices can also function as mercury emission control systems. ${ }^{24}$

Electrostatic precipitator (ESP) control devices can achieve PM collection efficiencies greater than 99 percent. ${ }^{23}$ Gaseous mercury (both $\mathrm{Hg}^{0}$ and $\mathrm{Hg}^{2+}$ ) in the flue gas can potentially be adsorbed on the fly ash, and fly ash containing mercury will impart an electrical charge by the ESP and attracted to oppositely charged metal plates for collection. The particles collected on the plates will fall into a collection hopper and the waste solid in the hopper will be disposed. An ESP located downstream of the air heater where the temperature of the flue gas is between $130^{\circ} \mathrm{C}$ and $180^{\circ} \mathrm{C}$ is called as a "coldside" ESP and an ESP located upstream of the air heater where the temperature is 
between $315^{\circ} \mathrm{C}$ and $400^{\circ} \mathrm{C}$ is called as a "hot-side" ESP. ${ }^{23}$ Mercury will be bound in the particulate phase less in a "hot-side" ESP than in a "cold-side" ESP due to the contribution of temperature.

\section{F. Objective of This Study}

It can be learned from recent reports that the majority of mercury released from coal combustion will be removed with fly ash material before the flue gas is emitted into the atmosphere. The degree to which mercury can be adsorbed onto fly ash for subsequent capture in PM control devices is dependent on the speciation of mercury, the flue gas concentration of fly ash, and the properties of fly ash. The study of the physical and chemical properties of fly ash is critical in reducing mercury emissions.

It is currently believed that mercury is primarily adsorbed onto the unburned carbon in fly ash. Some research work has been concentrated on the loss on ignition (LOI) and the unburned carbon levels in fly ash. ${ }^{26}$ The understanding of the relationship between the LOI level and mercury bound in ash will be helpful to reduce mercury emissions in coal-fired power plants.

Specific surface area (SSA) of the fly ash is another important parameter because the active sites are major spots to absorb mercury. Some references indicate that the mercury in fly ash increases with the increasing of SSA. ${ }^{26}$ SSA, the characteristic properties of fly ash, can be determined by measuring the amount of surface area that is present per unit mass of the ash. There are different measuring methods for SSA such as nitrogen adsorption, water adsorption and ethylene glycol monoethyl ether (EGME). The EGME method is the most common method used. 
There are numerous major and minor elements or oxides such as $\mathrm{Cl}, \mathrm{S}, \mathrm{CaO}$, $\mathrm{Na}_{2} \mathrm{O}, \mathrm{K}_{2} \mathrm{O}, \mathrm{SiO}_{2}, \mathrm{Fe} 2 \mathrm{O} 3, \mathrm{MgO}, \mathrm{Al}_{2} \mathrm{O}_{3}, \mathrm{MnO}_{2}$, etc. in fly ash. It is very important to determine if there is some relationship between particulate-bound mercury and trace elements. The analysis results will be the key in unlocking the problem that more mercury needs to be bound in ash and removed by the post-combustion control equipment.

The fly ash samples were collected from a full-scale coal-fired power plant and analyzed using advanced analytical instruments. The regression model built on the analysis data of fly ash properties describes the direct relationship between particulatebound mercury concentration and fly ash properties. The function of the ESP could be evaluated through this investigation.

The full-scale research in a coal-fired power plant will provide the actual and reliable data and results needed to assist the coal-fired power generation industry better understand methods to reduce mercury emission in order to achieve increasing stringent environmental regulating goals in the $21^{\text {th }}$ century. 


\section{EXPERIMENTAL}

\section{A. 100 MWe Low-NOx Burner Utility Boiler}

The full-scale mercury field test was conducted on the Unit No. 1 boiler at a power generating station in Kentucky. Information about the unit configuration is given below in Table 1. The schematic diagram of the system is shown in Figure 1, including three mercury sampling and two corrosion-testing ports.

Table 1. Configuration of Unit \#1 Boiler in the Power Plant

\begin{tabular}{ll}
\hline Load capacity & $100 \mathrm{MW}_{\mathrm{e}}$ \\
Boiler type & B\&W, Front wall fired with 3 rows of three burners \\
$\mathrm{PM}$ control type & Cold-side ESP \\
$\mathrm{SO}_{2}$ control & None \\
$\mathrm{NO}_{\mathrm{x}}$ control type & Low- $\mathrm{NO}_{\mathrm{x}}$ burners \\
\hline
\end{tabular}

A conveyer belt transported coal from the coal yard to 3 coal hoppers. The primary air carries the coal fines into the boiler through nine low- $\mathrm{NO}_{\mathrm{x}}$ burners. The secondary air is injected into the boiler through a wind box around the low- $\mathrm{NO}_{\mathrm{x}}$ burners. There are four ash discharge locations including bottom ash at the bottom of the boiler, one ash hopper before the air pre-heater and 4 mechanical hoppers just after the air preheater and 6 hoppers associated with cold the ESP. 


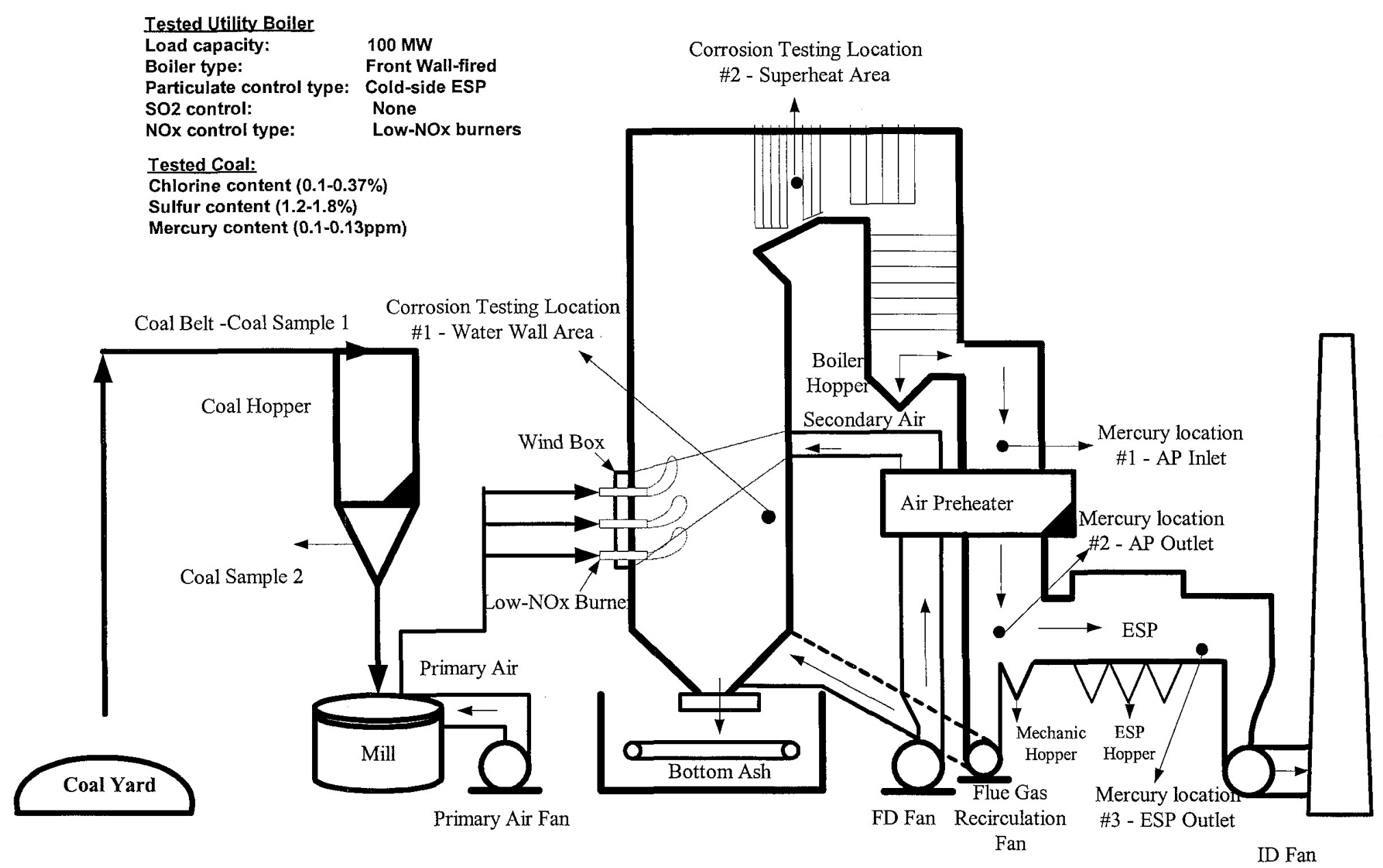

Figure 1. The configuration of the sampling 100 MWe Low-NOx Burner Utility Boiler. 
The air pollution control device (APCD) installed in the test boiler is a cold-side ESP at $300^{\circ} \mathrm{F}$. The fly ash sampling location, mechanical hoppers and the ESP hoppers are shown in Figure 1. Both of their temperatures are approximately $300^{\circ} \mathrm{F}$.

\section{B. Instrumental}

\section{LECO AMA-254 Mercury Analyzer}

The mercury content in coal and ash samples was analyzed by a LECO AMA-254 following ASTM method D6722. The detection limit for mercury is $0.01 \mathrm{ng}$ and test range is from $0.05 \mathrm{ng}$ to $600 \mathrm{ng}$. Small nickel boats are used in the analysis, and the calibration standard is NIST SRM 1633b for coal and ash. It takes six minutes for each sample with a furnace temperature at $750^{\circ} \mathrm{C}$.

The AMA-254 decomposes the coal and ash sample in an oxygen-rich environment by direct combustion, traps all vapor mercury on a gold-plated ceramic tube after removing the interfering elements, and analyzes the mercury concentration using a standard atomic absorption spectrophotometer.

\section{LECO TGA-601}

The Loss on Ignition (LOI) of coal and ash samples was analyzed using a LECO TGA-601 Thermo gravimetric analyzer. The TGA-601 measures sample weight loss as a function of temperature in a controlled environment. This instrument consists of a balance, an electronic chassis for furnace control and data management, and a multiple sample furnace, which can be heated from $100^{\circ} \mathrm{C}$ to $1000^{\circ} \mathrm{C}$ and allows up to 19 samples to be analyzed simultaneously. The sample weight range is from $1 \mathrm{~g}$ to 5 grams. The balance precision is $0.0001 \mathrm{~g}$ and instrument precision is $0.03 \%$. The atmosphere used in analysis is $99.5 \%$ oxygen. 


\section{LECO CHN-2000}

A LECO CHN-2000 Carbon, Hydrogen and Nitrogen Analyzer was used in the study. The CHN-2000 is a non-dispersive, infrared, microcomputer-based instrument. The coal and ash samples combust in the furnace with oxygen gas, and the elements carbon, hydrogen and nitrogen in samples are converted into $\mathrm{CO}_{2}, \mathrm{H}_{2} \mathrm{O}, \mathrm{N}_{2}$ and $\mathrm{NO}_{\mathrm{x}}$. These gases are then passed through the infrared (IR) cells to determine the carbon and hydrogen content and a thermal conductivity (TC) cell to determine nitrogen. The furnace can be heated from $0^{\circ} \mathrm{C}$ to $1000^{\circ} \mathrm{C}$. In general, $0.100 \mathrm{~g}$ sample is loaded and analyzed. The test range (based on a $0.100 \mathrm{~g}$ sample) is $0.01-100$ percent for carbon, 0.01-50 percent for hydrogen, and 0.01-50 percent for nitrogen. The instrument has 1 sigma accuracy at 0.001 for carbon and 0.01 for hydrogen and nitrogen.

\section{4. $\underline{\text { LECO SC-432 }}$}

The sulfur contents in coal and ash samples were measured using a LECO SC-432 Sulfur Analyzer. The samples are weighed into ceramics combustion boats and loaded into the SC-432, where they combust in the pure oxygen environment. The sulfur in the samples is oxidized to form $\mathrm{SO}_{2}$ in the evolved gas, which will be analyzed by the dedicated sulfur detection IR cell. The nominal sample weight for analysis is $350 \mathrm{mg}$ for coal. The test range is $0.01-100 \%$ sulfur with the accuracy at $\quad 0.005$ percent. The 99.5 percent oxygen is required for the analysis.

\section{LECO AC350 and Dionex DX 120 Ion Chromatograph}

The calorific contents in coal and ash samples were measured using a LECO AC350 Calorimeter, a digital signal processing (DSP) microprocessor based instrument. The calorific value of a sample is determined by burning the sample in a controlled environment. The heat released by combustion is proportional to the calorific value of 
the substance. The nominal sample weight is from $0.6 \mathrm{~g}$ to $1.4 \mathrm{~g}$. The measurement range is from $6000 \mathrm{BTU} / \mathrm{lb}$ to $15000 \mathrm{BTU} / \mathrm{lb}$ (for $1 \mathrm{~g}$ sample) with a precision of 0.05 percent. In general, 99.99 percent oxygen purge is required for the analysis.

A Dionex DX 120 Ion Chromatograph was used to analyze the chlorine content in the samples. The Dionex DX 120 Ion Chromatograph performs isocratic ion analysis using ion conductivity detection. It consists of a pump, column, detector, and injection valve. The solution containing chloride ion that can be processed from the AC350 is injected into the IC instrument. Ions in solution conduct electrical current when voltage is applied between electrodes contacting the solution. The conductivity detection is useful for quantifying some ions such as chloride in coal and ash. The pump flue range is from 0.5 to $4.5 \mathrm{~mL} / \mathrm{min}$ and the maximum pressure is $28 \mathrm{Mpa}$. The detector is full-scale with $1000 \mu$ s and the active volume of cell is $1.25 \mu \mathrm{L}$.

\section{XRF}

The major and minor elements in coal and ash samples were analyzed using a Rigaku RIX 3001 X-Ray Fluorescence Spectrometer. The RIX 3001 is a multipurpose tool for analyzing element composites. After the sample preparation, it is loaded in the instrument and irradiated with a beam of fluorescent X-rays. The wavelengths of these fluorescent X-rays are characteristic of the elements in the coal and ash samples. The fluorescent X-rays are dispersed by an analyzing crystal and detected with a scintillation counter or a flue proportional counter. The characteristic fluorescent X-rays have an intensity that is proportional to the number of excited atoms of the elements so that the concentration of elements in the sample can be determined by the intensity of the element and the computer controller can calculate the results automatically. The RIX 3001 can measure elements from ${ }_{4} \mathrm{Be}$ to ${ }_{92} \mathrm{U}$. $\mathrm{LiF}$ is used as analyzing crystal. A scintillation 
counter was used to detect heavy elements, and a gas flue proportional counter is used to measure light elements. The Goniometric scan range is from $5^{\circ}$ to $118^{\circ}$ for the $\mathrm{SC}$ and $8^{\circ}$ to $148^{\circ}$ for the F-PC.

\section{Coal Resources Studied}

Seven coals with different mercury, chlorine and sulfur levels were tested. The mercury, chlorine and sulfur contents were in the ranges of 0.1 to $0.13 \mathrm{ppm}, 0.1$ to $0.37 \%$ and 1.2 to $1.8 \%$, respectively. Results of the proximate and ultimate analysis of tested coals are shown in Table 2. The XRF results for ashes prepared from the coal are shown in Table 3.

\section{Analysis Procedure for Solid Samples}

The fly ash samples were collected from the mechanical hopper and the ESP hopper during the OHM and SCEM sampling periods.

The mercury contents in fly ash samples were analyzed using a LECO AMA-254 mercury analyzer. Approximately $0.02-1 \mathrm{~g}$ of an ash sample was loaded into the nickel boat and the instrument and computer software analyzed the test result and showed the mercury concentration in fly ash.

The unburned carbon content in fly ash was analyzed using a LECO CHN2000 analyzer according to ASTM Method D5373. An autoloader was used to handle the sample throughput after weighing. Five blanks were run to calibrate the instrument and three approximately $0.1000 \mathrm{~g}$ standard samples were weighed and folded and sealed into black foil holder. The standard samples were loaded into the instrument and the analysis results were displayed and printed. After confirming the results matched the standard 
Table 2. Average Results from Coal Sample Proximate and Ultimate Analysis. ${ }^{\text {A }}$

\begin{tabular}{lccccccc}
\hline Sample ID & Coal \#1 & Coal \#2 & Coal \#3 & Coal \#4 & Coal \#5 & Coal \#6 & Coal \#7 \\
\hline Moisture, \% & 2.63 & 2.60 & 2.76 & 3.73 & 7.73 & 4.69 & 3.25 \\
Ash, \% & 9.60 & 9.89 & 9.63 & 8.61 & 10.93 & 8.37 & 16.20 \\
Volatile Matter, \% & 32.89 & 32.86 & 35.89 & 36.39 & 38.57 & 37.81 & 36.12 \\
Fixed Carbon, \% & 54.88 & 54.64 & 51.72 & 51.27 & 45.68 & 53.83 & 45.68 \\
C, \% & 75.79 & 75.84 & 74.81 & 75.61 & 75.18 & 76.58 & 68.89 \\
H, \% & 5.00 & 5.04 & 4.83 & 4.88 & 4.77 & 5.64 & 4.81 \\
N, \% & 1.77 & 1.66 & 1.58 & 1.67 & 1.42 & 1.66 & 1.58 \\
S, \% & 1.30 & 1.78 & 1.20 & 1.19 & 1.42 & 1.41 & 2.04 \\
O, \% & 6.54 & 5.78 & 7.95 & 8.03 & 6.28 & 6.34 & 6.48 \\
Hg, \% & 0.12 & 0.10 & 0.11 & 0.13 & 0.06 & 0.12 & 0.24 \\
F, \% & 0.0115 & 0.0031 & 0.0047 & 0.0084 & 0.0097 & 0.0092 \\
Cl, \% & 0.15 & 0.09 & 0.13 & 0.12 & 0.36 & -
\end{tabular}

${ }^{A}$ all values, except moisture, are given on a dry basis. 
Table 3. Concentrations of Major and Minor Element Oxides in Ashes Prepared from Test Coals.

\begin{tabular}{|c|c|c|c|c|c|c|c|}
\hline Sample ID & Coal \#1 & Coal \#2 & Coal \#3 & Coal \#4 & Coal \#5 & Coal \#6 & Coal \#7 \\
\hline $\mathrm{Na}_{2} \mathrm{O}, \%$ & 0.47 & 0.37 & 0.45 & 0.33 & 1.07 & 1.11 & 0.33 \\
\hline $\mathrm{MgO}, \%$ & 1.00 & 1.12 & 1.07 & 1.17 & 1.10 & 0.71 & 1.12 \\
\hline $\mathrm{Al}_{2} \mathrm{O}_{3}, \%$ & 25.11 & 26.05 & 26.71 & 22.82 & 21.57 & 23.31 & 24.24 \\
\hline $\mathrm{SiO}_{2}, \%$ & 50.59 & 50.43 & 52.69 & 50.11 & 49.53 & 49.42 & 47.47 \\
\hline $\mathrm{CaO}, \%$ & 1.45 & 0.97 & 1.51 & 2.85 & 2.18 & 1.94 & 1.08 \\
\hline $\mathrm{K}_{2} \mathrm{O}, \%$ & 1.86 & 2.69 & 2.18 & 2.26 & 2.59 & 2.83 & 3.55 \\
\hline $\mathrm{SO}_{3}, \%$ & 1.24 & 1.04 & 1.41 & 2.24 & 1.39 & 1.32 & 0.77 \\
\hline $\mathrm{P}_{2} \mathrm{O}_{5}, \%$ & 0.24 & 0.21 & 0.30 & 0.17 & 0.43 & 0.36 & 0.22 \\
\hline $\mathrm{BaO}, \%$ & 0.20 & 0.20 & 0.26 & 0.20 & 0.00 & 0.06 & 0.09 \\
\hline $\mathrm{SrO}, \%$ & 0.11 & 0.11 & 0.20 & 0.09 & 0.08 & 0.09 & 0.07 \\
\hline $\mathrm{Fe}_{2} \mathrm{O}_{3}, \%$ & 12.38 & 15.25 & 8.82 & 12.23 & 14.56 & 14.95 & 17.68 \\
\hline $\mathrm{MnO}_{2}, \%$ & 0.017 & 0.015 & 0.016 & 0.047 & 0.025 & 0.023 & 0.028 \\
\hline $\mathrm{TiO}_{2}, \%$ & 1.43 & 1.17 & 1.49 & 1.13 & 1.24 & 1.36 & 1.17 \\
\hline
\end{tabular}


value, the coal and ash samples were weighed and analyzed by the instrument. Two runs were made for each sample, and the final results came from the average of the two. The concentration of carbon, hydrogen and nitrogen were displayed on the computer screen and the printer.

For LOI (ASTM D5142) and moisture analysis, approximately $1 \mathrm{~g}$ ash sample was put into a LECO TGA-601. Following the standard program, the weight difference for the sample between before and after the test was recorded and LOI was determined.

The Specific Surface Area (SSA) of fly ash samples was analyzed using the EGME method. The $\mathrm{CaCl}_{2}$-EGME solvate was prepared by mixing $20 \mathrm{~g}$ ethylene glycol monoethyl ether in $100 \mathrm{~g}$ of hot calcium chloride and dried at $210^{\circ} \mathrm{C}$ for 1 hour. After the solvate had cooled, it was transferred to a culture chamber and spread uniformly over the bottom. The fly ash samples were saturated with calcium ions by leaching with an excess of $1.0 \mathrm{M} \mathrm{CaCl}_{2}$. The samples were air dried, after the excess $\mathrm{CaCl}_{2}$ was removed by water washing, and then passed through a 60-mesh sieve. Approximately $1.1 \mathrm{mg}$ pretreated ash samples were weighed into aluminum cans and oven-dried at $110^{\circ} \mathrm{C}$ for 24 hours. The oven-dried samples were wet with $3 \mathrm{~mL}$ EGME after weighed. The cans were placed in the culture chamber with $\mathrm{CaCl}_{2}$-EGME and the entire culture chamber was placed in a vacuum desiccator containing $\mathrm{CaCl}_{2}$. The desiccator was evacuated by applying a vacuum pump for about 45 min after equilibrating for $30 \mathrm{~min}$. After letting stand for 4-6 hours, the samples were weighed. The procedure of evacuating-standingweighing was repeated several times until the weight change was less than $0.1 \mathrm{mg}$ between successive weightings. The SSA was calculated using the following equation:

$$
\mathrm{A}=\mathrm{W}_{\mathrm{a}} /\left(\mathrm{W}_{\mathrm{s}} * 0.000286\right)
$$


Where $\mathrm{A}=$ specific surface area in $\mathrm{m}^{2} / \mathrm{g}, \mathrm{W}_{\mathrm{a}}=$ weight of EGME retained in the sample in $\mathrm{g}, \mathrm{W}_{\mathrm{s}}=$ weight of oven dried sample in $\mathrm{g}$, and 0.000286 is the weight of EGME required to form a monomolecular layer on a square meter of surface.

A Rigaku RIX 3001 was used to analyze the major, minor and some trace elements in the coal and fly ash samples. The samples were heated first to oxidize all carbonaceous material and to decompose minerals containing carbonates, sulfides, and hydroxides in air atmosphere. The samples were heated in a flat ceramic dish in a furnace. The temperature of the furnace was raised to $500^{\circ} \mathrm{C}$ in one hour and to $750^{\circ} \mathrm{C}$ in two hours. After reaching $750^{\circ} \mathrm{C}$, the furnace was kept isothermal for an additional two hours. For XRF analysis, the glass pellets were prepared following ASTM Methods D4326. A $0.4000 \mathrm{~g}$ fired ash and $4.8 \mathrm{~g} \mathrm{Li}_{2} \mathrm{~B}_{4} \mathrm{O}_{7}$ plus $0.5 \mathrm{~g} \mathrm{NH} 4 \mathrm{I}$ were mixed together and ground for 10 minutes. The mixture was poured into a platinum crucible and put into the $1000^{\circ} \mathrm{C}$ furnace isothermal for seven minutes. The melted sample was then poured into a pellet dish and allowed to cool. The pellet sample was analyzed on the XRF following the appropriate method. The XRF instrument was calibrated first and the standard baseline for thirteen elements was built into the method. The samples were loaded into the instrument automatically and the results were shown in the screen and printed.

The LECO AC350 was used for measuring the calorific value of coal samples and preparing test solutions for chloride analysis using a Dionex DX 120 Ion Chromatograph. Benzoic acid pellets were used to calibrate the AC350 instrument before any samples and after every ten samples. Each sample was run twice; the result was the average of the two results assuming their difference was less than 50 BTU/LB on a dry basis. The residue from the coal or ash sample in the bomb was rinsed into a volumetric flask using 
DI water and $1 \mu \mathrm{L}$ of the solution was injected into the IC. The concentration of chloride ion was displayed on the screen and printer.

The sulfur content in coal and fly ash was measured using a LECO SC432 according to ASTM Method D4239. The analysis was carried out at $1350^{\circ} \mathrm{C}$ in an oxygen atmosphere. The instrument was calibrated using standard samples before the tests. Approximately $200 \mathrm{mg}$ coal or ash samples were weighed, put into the ceramic boat, and loaded into the instrument. The results were shown on the screen and printed. Each sample was measured twice to determine that if the repeatability was good. The average of the two runs was the result for the sample.

The analysis results for unburned carbon, LOI, SSA, metal oxides and other elements were calculated, analyzed and regressed using Microsoft Excel, Origin and Minitab statistics software packages to evaluate their effects and relationship with particulate-bound mercury. The importance of these factors was discussed and compared. The regression models were built to describe the relationship between $\mathrm{Hg}^{\mathrm{P}}$ and fly ash properties. 


\section{RESULTS AND DISCUSSION}

\section{A. Mercury Removal and Particulate-bound Mercury}

The ESP control efficiency was presented as the ratio of total mercury captured in the mechanical hopper and the ESP hopper to total coal mercury input. Based on the OHM results, the mercury removal efficiencies by combination of the mechanical hopper and the cold-side the ESP varied in the range of $25 \%$ to $60 \%$, which is dependent on coal and ash properties. The mercury concentration of the coal feed to the boiler ranged from 0.06 to $0.24 \mathrm{ppm}$. The mercury concentration in the flue gas ranged from 0.45 to 2.66 ppb. A portion of the mercury in the flue gas was bound into the fly ash thus reducing the mercury emission before the flue gas was emitted from the stack. The properties of fly ash are very important to the amount of mercury bound in ash.

The average analysis results for fly ash samples collected from mechanical hopper and the ESP hopper are shown in Tables 4 and Table 5. It can be observed that the mercury concentration in the ash collected from the ESP hopper is higher than the sample

collected from the mechanical hopper. The data indicate that the various properties of the fly ash from the MHP and the ESP influence the mercury bound in fly ash. 
Table 4. Average Analysis Results of Fly Ash from the MHP.

\begin{tabular}{lcccccc}
\hline \multicolumn{2}{l}{ Sample ID Carbon, \% } & LOI, \% & S, \% & Cl, ppm & F, ppm & Hg, ppm \\
\hline Coal \#1 & 5.21 & 5.50 & 0.11 & 130 & 50 & 0.09 \\
Coal \#2 & 4.07 & 4.08 & 0.11 & 100 & 36 & 0.06 \\
Coal \#3 & 7.80 & 8.40 & 0.25 & 79 & 57 & 0.11 \\
Coal \#4 & 9.52 & 11.69 & 0.20 & 141 & 262 & 0.23 \\
Coal \#5 & 6.79 & 6.84 & 0.11 & 169 & 28 & 0.12 \\
Coal \#6 & 5.60 & 6.76 & 0.18 & 510 & 83 & 0.11 \\
Coal \#7 & 2.06 & 3.07 & 0.10 & 189 & -- & 0.09 \\
\hline
\end{tabular}

Table 5. Average Analysis Results of Fly Ash from the ESP.

\begin{tabular}{lcccccc}
\hline \multicolumn{2}{l}{ Sample ID Carbon, \% } & LOI, \% & S, \% & Cl, ppm & F, ppm & Hg, ppm \\
\hline Coal \#1 & 4.91 & 5.84 & 0.62 & 107 & 195 & 0.41 \\
Coal \#2 & 3.90 & 5.17 & 0.63 & 127 & 610 & 0.30 \\
Coal \#3 & 5.30 & 6.51 & 0.47 & 132 & 149 & 0.59 \\
Coal \#4 & 6.57 & 7.56 & 0.57 & 222 & 303 & 1.11 \\
Coal \#5 & 6.89 & 7.72 & 0.41 & 221 & 107 & 0.99 \\
Coal \#6 & 3.90 & 5.12 & 0.67 & 530 & 181 & 0.67 \\
Coal \#7 & 2.41 & 3.44 & 0.59 & 200 & -- & 0.30 \\
\hline
\end{tabular}




\section{B. Unburned Carbon and LOI Regression}

From Tables 4 and 5 it can be learned that with an increase in the amount of unburned carbon and loss on ignition, the mercury concentration in the fly ash increases. The plots of mercury concentration and unburned carbon and LOI are shown in Figures 2-5, which describe their relationship clearly. The regression model for unburned carbon, LOI and $\mathrm{Hg}^{\mathrm{p}}$ was built for the statistical assumptions that can illustrate their direct relationship. If there is a good linear trend, the interference effects can be learned by regression.

The regression equation, coefficients, R-Square, T-ratio, F-statistics, and P-value are important factors that can evaluate the results of a regression. Coefficients are the estimates of the parameters in a regression equation. The coefficients are used, along with the independent variables, to calculate the fitting value of the dependent variable. RSquare is also called the coefficient of determination that can tell the relationship between the variations and predictors. In this study, it is acceptable if R-Square is larger than 70 percent. P-values are used in hypothesis tests that R-Square is zero. The regression model is satisfied with the P-values less than 0.05 . The P-value helps to determine the statistical significance of the F-statistic that indicates how much the predictor fits the regression hypothesis. T-ratios are for the examinations of autocorrelations and partial autocorrelations. One commonly used rule is that a Tstatistic with an absolute value greater than 2 satisfies the regression relationship. The higher the coefficients and T-ratio with the lower P-values, the more the statistical assumptions are satisfied. The regression factors are shown in Table 6 .

From the fitting line in Figures 2-5, it can be observed that the $\mathrm{Hg}^{\mathrm{p}}$ increases as the quantity of the unburned carbon and LOI for fly ash either at the MHP or at the ESP 


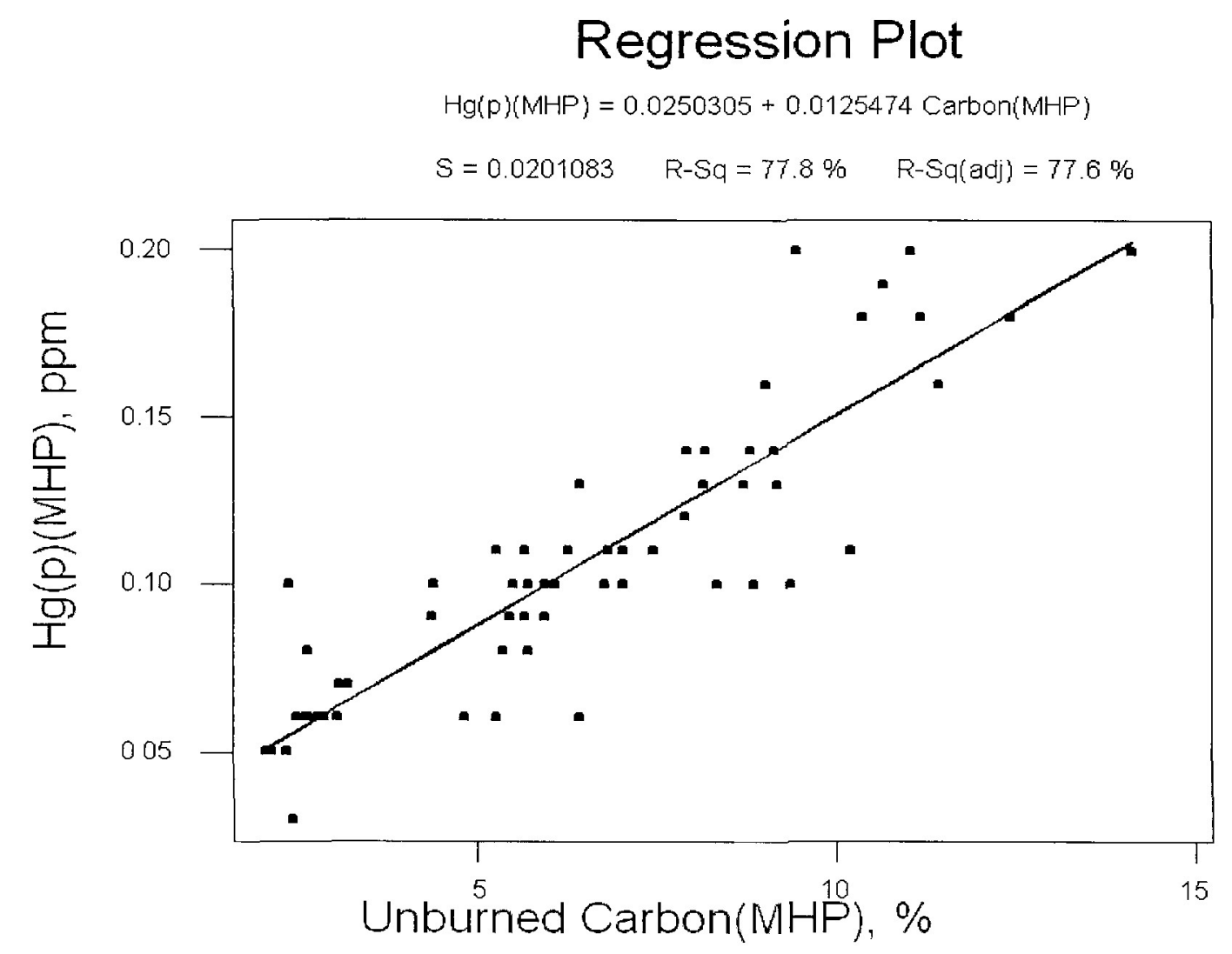

Figure 2. Regression plot of particulate mercury concentration vs. unburned carbon concentration in fly ash collected from the mechanical hopper. 


\section{Regression Plot}

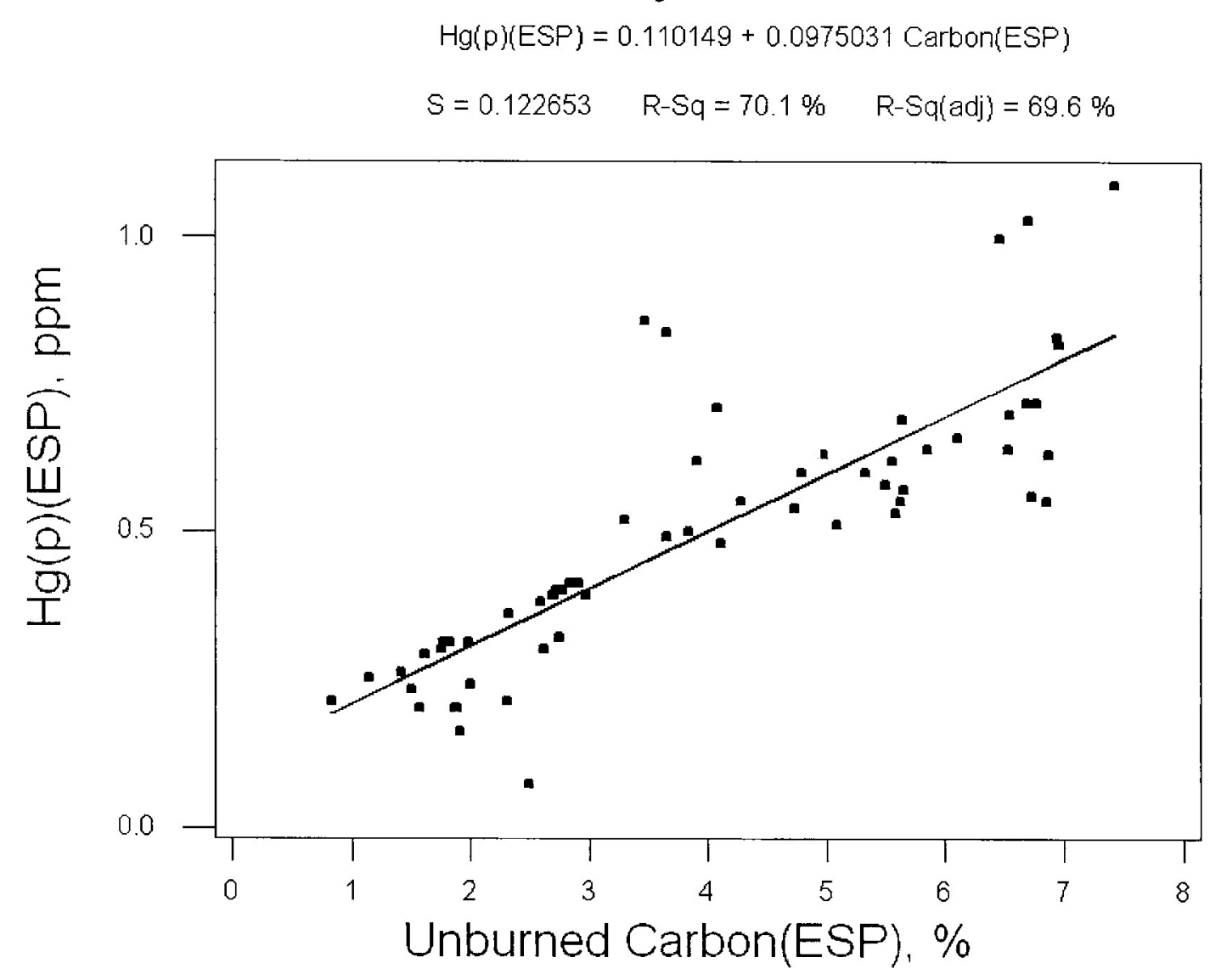

Figure 3. Regression plot of particulate mercury concentration vs. unburned carbon concentration in fly ash collected from the electrostatic precipitator. 


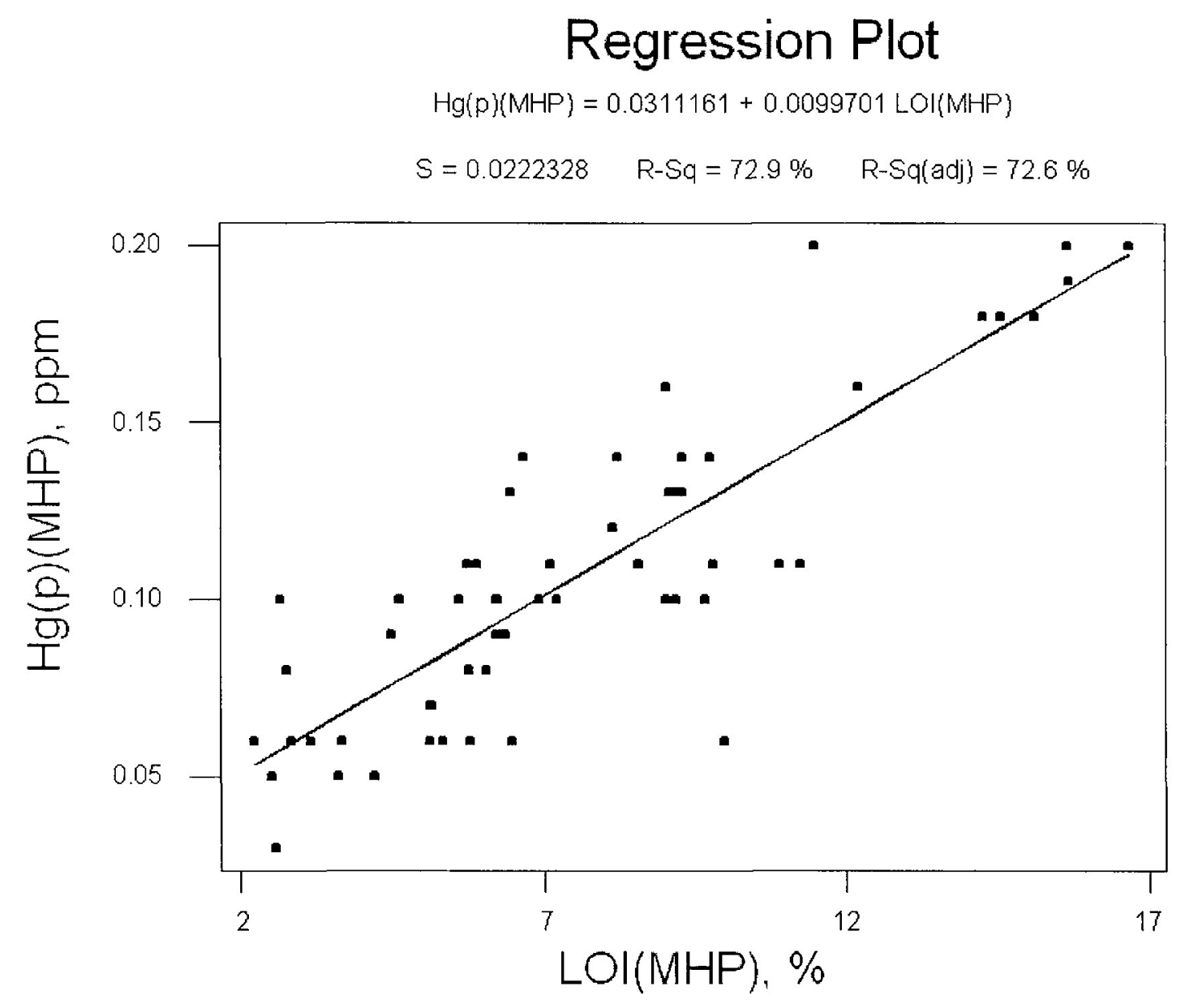

Figure 4. Regression plot of particulate mercury concentration vs. LOI in fly ash collected from the mechanical hopper. 


\section{Regression Plot}

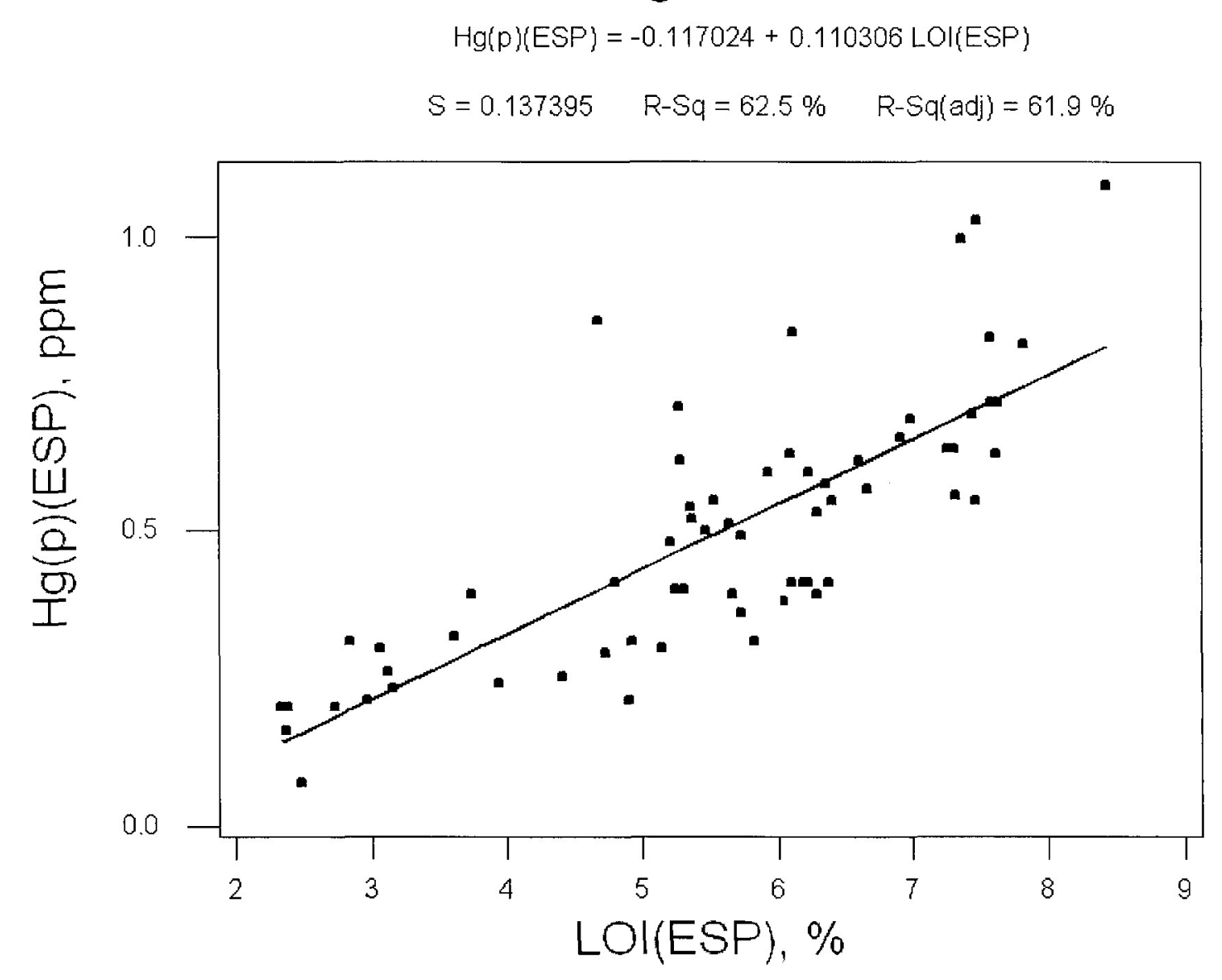

Figure 5. Regression plot of particulate mercury concentration vs. LOI in fly ash collected from the electrostatic precipitator. 
increases. The regression plots show that the slope for $\mathrm{Hg}^{\mathrm{p}}$-unburned carbon is somewhat larger than $\mathrm{Hg}^{\mathrm{p}}$-LOI, an indication that the unburned carbon content in fly ash is more important than LOI. The different R-square value shows the same trend.

For the fly ash collected from the MHP, the regression equation can be illustrated as: $\mathrm{Hg}^{\mathrm{p}}(\mathrm{MHP}), \mathrm{ppm}=0.0230+0.00838$ Carbon $(\mathrm{MHP}), \%+0.00385$ LOI $(\mathrm{MHP}), \%$. The coefficient for unburned carbon is 0.00838 , higher than for LOI. The T-ratio of 6.35 for unburned carbon is higher than that of LOI at 3.55. Also the P-value of unburned carbon is lower than LOI. The detailed regression analysis is shown in Table 6. These results indicate that statistically the mercury concentration in fly ash is more dependent on unburned carbon than LOI.

Similar to the regression results for ash collected from the MHP, the relationship between $\mathrm{Hg}^{\mathrm{p}}$, unburned carbon and LOI at the ESP can be represented as the following: $\mathrm{Hg}^{\mathrm{p}}$ (ESP), $\mathrm{ppm}=-0.0180+0.0670$ Carbon (ESP), $\%+0.0448$ LOI (ESP), \%. The equation shows the same trend as that $\mathrm{Hg}^{\mathrm{p}}$ increases with an increase in unburned carbon and LOI, and unburned carbon shows a more significant effect on mercury bound in ash particles because of the higher coefficient, T-ratio and lower p-value for unburned carbon.

Comparing the regression analyzed for fly ash at the MHP and ESP, both the Fstatistic and P-value can satisfy the model regression, but the R-square and F-statistic at the MHP are higher than at the ESP. The coefficients for unburned carbon and LOI at the MHP are lower than the coefficient at the ESP which explains the reason for higher $\mathrm{Hg}^{\mathrm{p}}$ at the ESP than the MHP.

Currently, the materials that lead to LOI are difficult to define, but the effect of unburned carbon for $\mathrm{Hg}$ bound in fly ash is undisputed. For the fly ash collected from the 
same location, as the quantity of unburned carbon in the fly ash increases, the more mercury can be bound in the ash and removed from the flue gas. The above regression equations only show the relationship among the $\mathrm{Hg}^{\mathrm{p}}$-unburned carbon-LOI. There are still some other factors influencing mercury concentration in the fly ash. With similar unburned carbon concentrations and LOIs at the MHP and ESP, the $\mathrm{Hg}^{\mathrm{P}}$ is obviously different. There must be some other properties of fly ash that affect the $\mathrm{Hg}^{\mathrm{P}}$.

Table 6. Regression Analysis of $\mathrm{Hg}^{\mathrm{p}}$-Carbon-LOI at the MHP and ESP.

\begin{tabular}{ccccccc}
\hline $\begin{array}{c}\text { Regression } \\
\text { Predictor }\end{array}$ & R-Square & F-Statistic & P-Value & Coefficient & T-ratio & P-Value \\
\hline Hg $^{\mathrm{p}}$ (MHP)- & & & & & & \\
Carbon(MHP)- & $80.1 \%$ & 224.76 & 0 & & - & - \\
LOI (MHP) & & & & & & \\
Carbon (MHP) & & - & & 0.00838 & 6.35 & 0 \\
LOI (MHP) & & - & & 0.00385 & 3.55 & 0.001 \\
Hg & & & & & & \\
Carbon (ESP)- & $73.50 \%$ & 84.78 & 0 & - & - & - \\
LOI (ESP) & & & & & & \\
Carbon (ESP) & - & - & - & 0.06700 & 5.05 & 0 \\
LOI (ESP) & - & - & & 0.04479 & 2.82 & 0.007 \\
\hline
\end{tabular}




\section{The Effect of Specific Surface Area}

When the fly ash in flue gas pass through the ESP, the small particle ash is much easier to be charged and collected by the ESP plates because of their smaller mass and volume. The ash surface area is an important factor that can affect the mercury absorption by fly ash. The SSA analysis results for ash collected from the MHP and the ESP are shown in Table 7.

Apparently, the SSA of fly ash at the MHP is much smaller than at the ESP. The average diameter of fly ash particles at the ESP is much smaller than that at the MHP. The smaller particles lead to larger available specific surface area that allows more mercury to be bound and held in the fly ash. The analysis results provide the evidence to determine the relationship between $\mathrm{Hg}^{\mathrm{p}}$ and SSA.

Through regression analysis, the relationship of $\operatorname{Hg}^{\mathrm{p}}(\mathrm{MHP})-\mathrm{SSA}(\mathrm{MHP})$ can be described as: $\mathrm{Hg}^{\mathrm{p}}(\mathrm{MHP})=0.0778+0.00519$ SSA (MHP) and the regression equation for ash at the ESP can be shown as: $\operatorname{Hg}^{\mathrm{p}}(\mathrm{ESP})=-0.034+0.0252$ SSA (ESP), the unit for $\mathrm{Hg}^{\mathrm{p}}$ is $\mathrm{ppm}$ and $\mathrm{m}^{2} / \mathrm{g}$ for SSA. For the smaller SSA ash at the MHP, the regression results can not satisfy the model because of the small R-square, F-statistic coefficient and T-ratio. The P-value for $\mathrm{Hg}^{\mathrm{P}}$-SSA at the MHP is 0.371 , larger than 0.05 , which indicates a poor relationship between $\mathrm{Hg}^{\mathrm{P}}$ and SSA at the MHP. The regression results for $\mathrm{Hg}^{\mathrm{p}}$ SSA at the ESP are much better than the MHP. With a R-square of $72.6 \%$, F-statistic of 13.22, coefficient of 0.02521 and large T-ratio of 3.64, the model of $\mathrm{Hg}^{\mathrm{p}}$-SSA at the ESP shows a very clear relationship between $\mathrm{Hg}^{\mathrm{p}}$ and SSA. For the fly ash collected at the ESP, the larger the SSA, the more mercury bound in ash particles. The poor relationship between $\mathrm{Hg}^{\mathrm{p}}$ and SSA at the MHP is the result of low mercury concentration as well as a small SSA. The regression plots are shown in Figures 6 and 7. 


\section{Regression Plot}

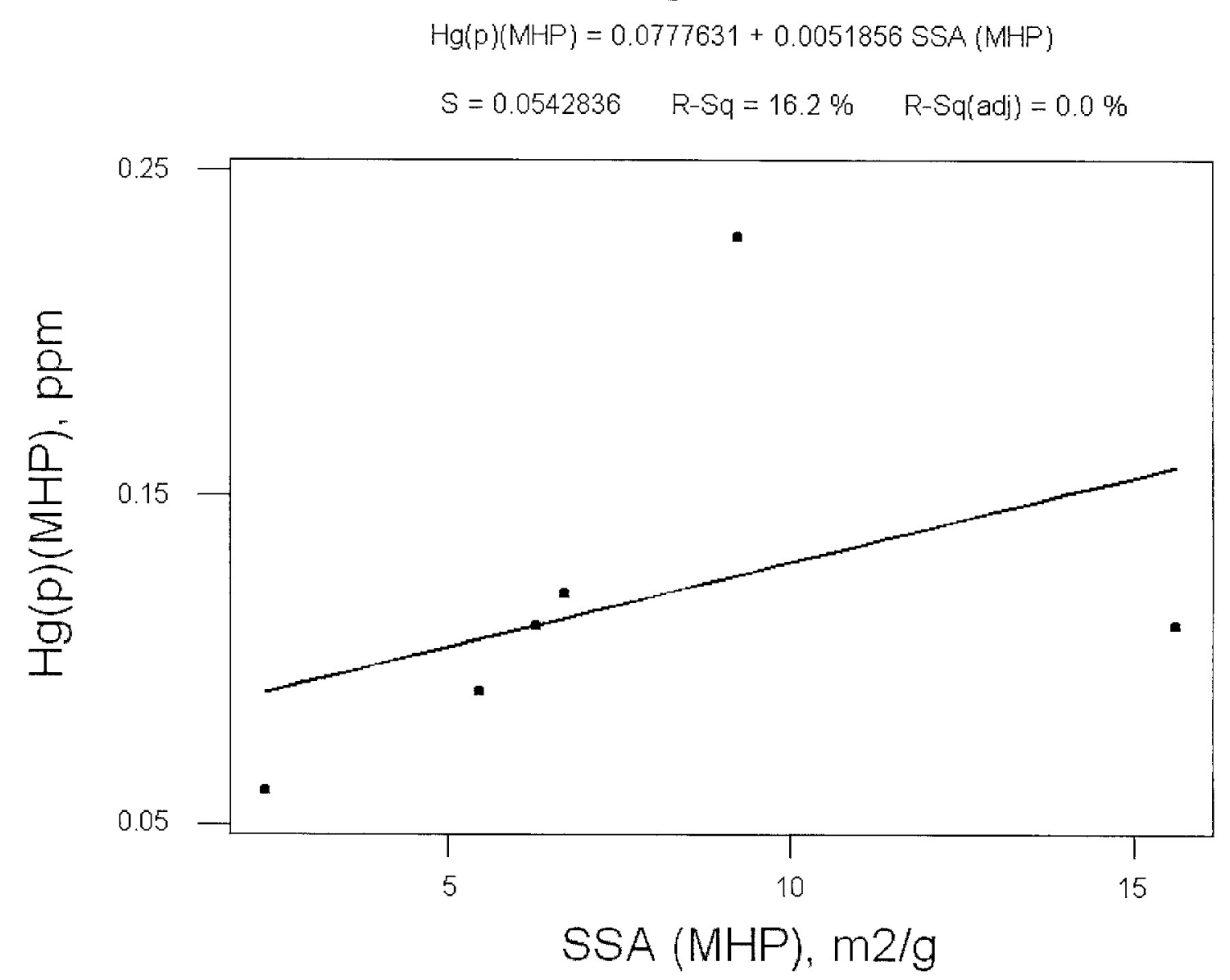

Figure 6. Regression plot of particulate mercury concentration vs. SSA of fly ash collected from the mechanical hopper. 
Regression Plot

$\mathrm{Hg}(\mathrm{p})(\mathrm{ESP})=-0.0337345+0.0252115$ SSA $(\mathrm{ESP})$

$S=0.185844 \quad$ R-Sq $=72.6 \% \quad$ R-Sq $\{$ adj $\}=671 \%$

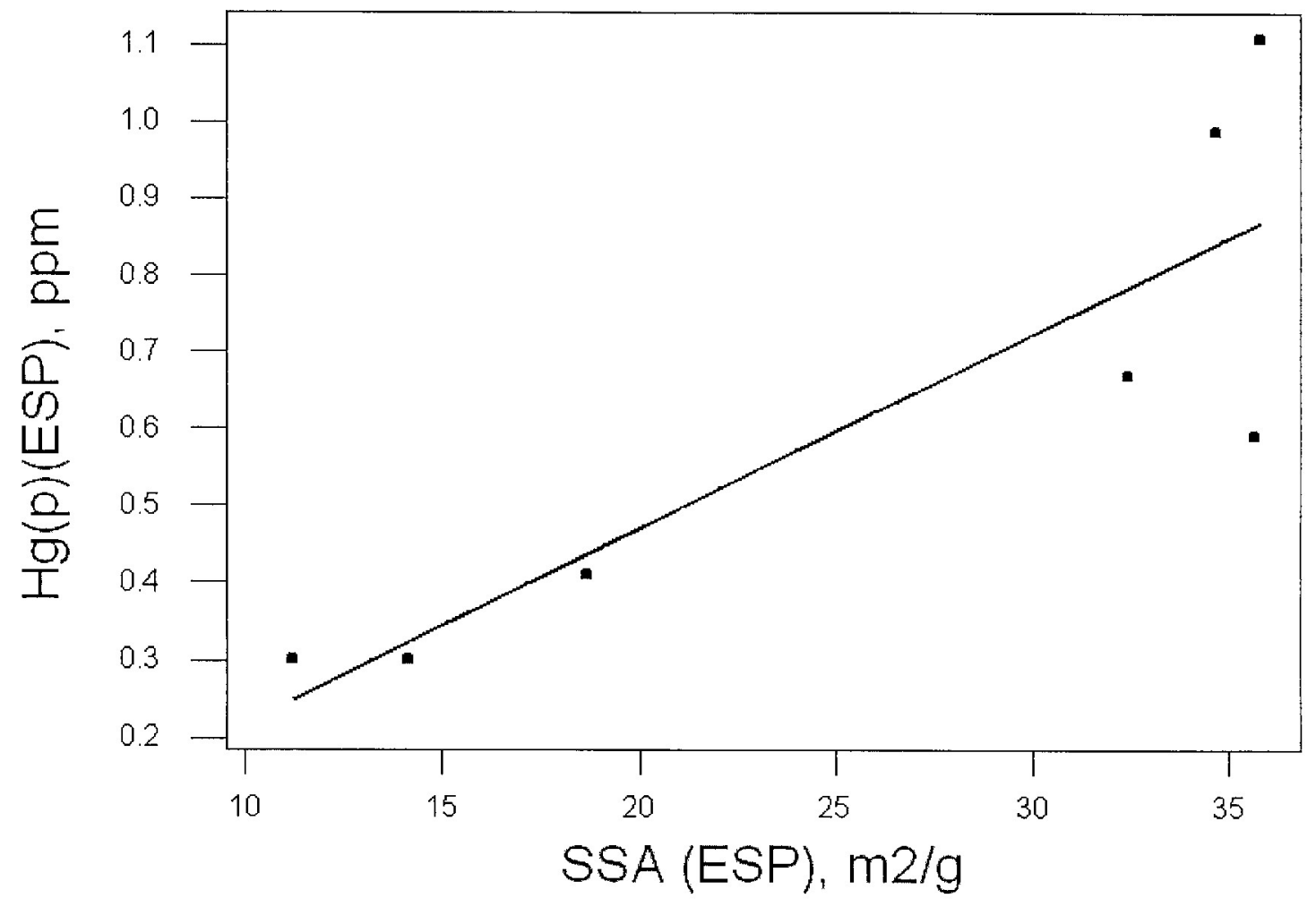

Figure 7. Regression plot of particulate mercury concentration vs. SSA of fly ash collected from the electrostatic precipitator. 
It can be observed that there are low mercury concentrations at high unburned carbon/LOI values in the MHP ash and there are high mercury concentrations in the ESP ash, even at low unburned carbon/LOI values compared to the MHP in some samples. For these cases, SSA plays a key role that influences the mercury concentration in the fly ash.

Table 7. SSA Analysis Results for Ash at the MHP and ESP

\begin{tabular}{|c|c|c|c|c|}
\hline Sample ID & (MHP), & MHP), & $(\mathrm{ESP}), \mathrm{m}^{2} / \mathrm{g}$ & $\mathrm{Hg}^{\mathrm{p}}(\mathrm{ESP}), \mathrm{ppm}$ \\
\hline Coal \#1 & 5.48 & 0.09 & 18.70 & 0.41 \\
\hline Coal \#2 & 2.36 & 0.06 & 11.23 & 0.30 \\
\hline Coal \#3 & 15.63 & 0.11 & 35.64 & 0.59 \\
\hline Coal \#4 & 9.25 & 0.23 & 35.82 & 1.11 \\
\hline Coal \#5 & 6.72 & 0.12 & 34.69 & 0.99 \\
\hline Coal \#6 & 6.31 & 0.11 & 32.46 & 0.67 \\
\hline Coal \#7 & 5.48 & 0.09 & 14.16 & 0.30 \\
\hline
\end{tabular}

Table 8. Regression Analysis of $\mathrm{Hg}^{\mathrm{p}}$-SSA.

\begin{tabular}{cccccc}
\hline $\begin{array}{c}\text { Regression } \\
\text { Predictor }\end{array}$ & R-Square & F-Statistic & Coefficient & T-ratio & P-Value \\
\hline $\mathrm{Hg}^{\mathrm{p}}$-SSA (MHP) & $16.2 \%$ & 0.96 & 0.00519 & 0.98 & 0.371 \\
& & & & & \\
$\mathrm{Hg}^{\mathrm{p}}$-SSA (ESP) & $72.6 \%$ & 13.22 & 0.02521 & 3.64 & 0.015 \\
\hline
\end{tabular}




\section{Regression Plot}

$\mathrm{Hg}(p)(\mathrm{MHP})=0.0905455+0.0470123 \mathrm{Na} 2 \mathrm{O}(\mathrm{MHP})$

$$
S=0.0500603 \quad R-S q=4.3 \% \quad R-S q\{\text { adj }\}=0.5 \%
$$

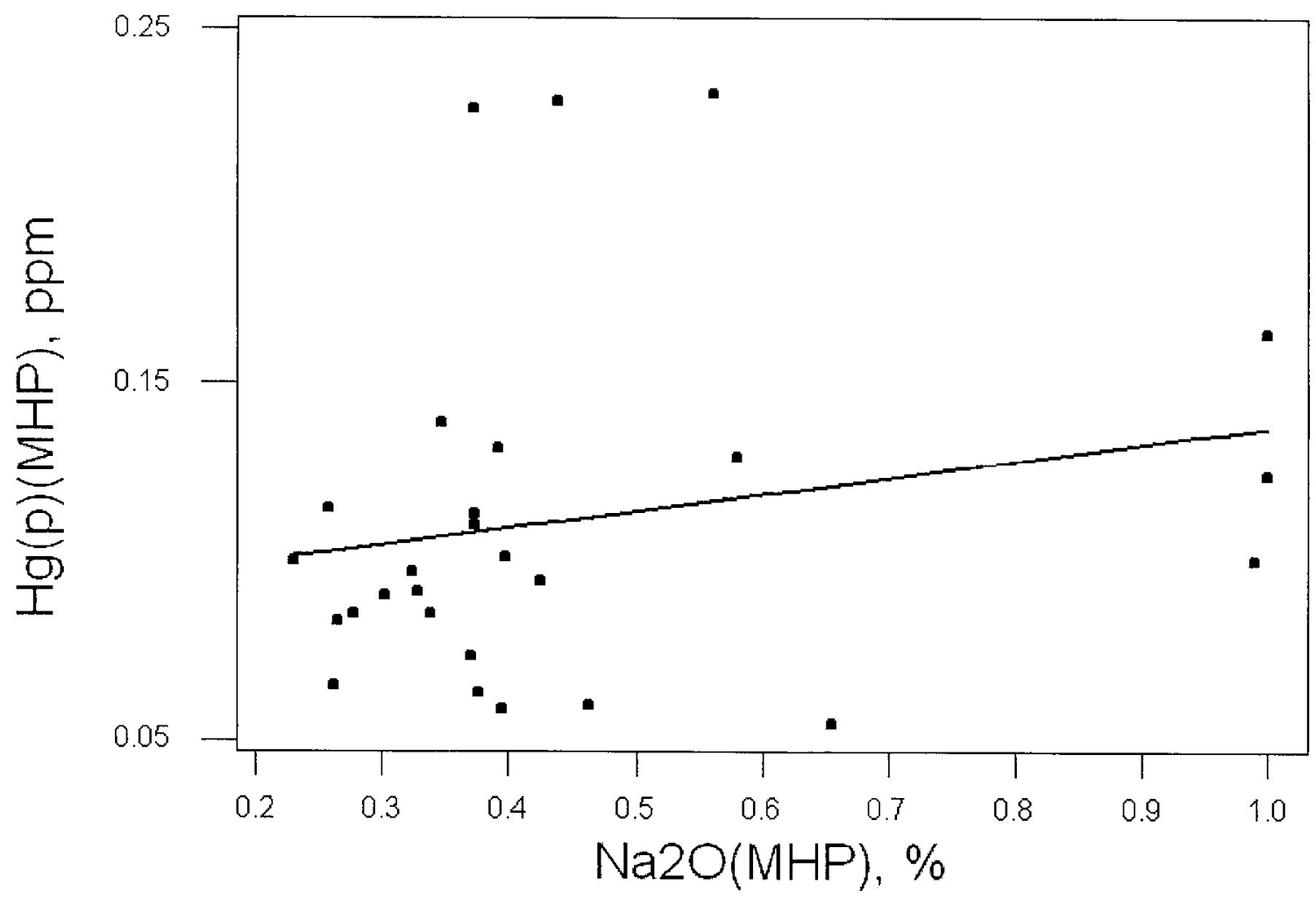

Figure 8. Regression plot of particulate mercury concentration vs. $\mathrm{Na}_{2} \mathrm{O}$ concentration in fly ash collected from the mechanical hopper. 
D. Major, Minor Metal Oxides, and Others Element Regression Analysis

Some of the element oxides may serve a function for mercury absorption by catalyzing or offering a surface absorption mechanism depending on their concentration in ash. According to the regression plots in Figures 8-20 that show the relation between the $\mathrm{Hg}^{\mathrm{p}}$ and metal oxides in the MHP ash, only some element oxides such as $\mathrm{Al}_{2} \mathrm{O}_{3}$, $\mathrm{MnO}_{2}$ and $\mathrm{SrO}$, show a small regression relationship with $\mathrm{Hg}^{\mathrm{p}}$. There is no significant effect from $\mathrm{Na}_{2} \mathrm{O}, \mathrm{MgO}, \mathrm{SiO}_{2}, \mathrm{CaO}, \mathrm{K}_{2} \mathrm{O}, \mathrm{SO}_{3}, \mathrm{P}_{2} \mathrm{O}_{5}, \mathrm{BaO}, \mathrm{Fe}_{2} \mathrm{O}_{3}$, and $\mathrm{TiO}_{2}$ in fly ash at the MHP based on the poor regression constants. The regression results in Table 9 provide further evidence that the regression R-Square factors for all the metal oxides are much smaller than 70 percent.

For the fly ash collected from the ESP, the regression plots are shown in Figures 21-33 and analysis results are summarized in Table 10. Similar to the ash at the MHP, there is a poor relationship between $\mathrm{Hg}^{\mathrm{p}}$ and these major and minor elements for the ESP ash. The highest R-Square among the regression analysis is only 51.2 percent for $\mathrm{MnO}_{2}$, much lower than 70 percent.

In the full-scale test, the sulfur and chlorine in fly ash does not show an obvious effect on $\mathrm{Hg}^{\mathrm{p}}$ in fly ash, as shown in Figures 34-39. The analysis results for sulfur from the SC432 and IC are close. Only for ash from the ESP, the plot of mercury versus S/C1 shows a better linear relationship with the R-Square of $24.1 \%$ and lower P-value of 0.046. For the regression model for sulfur and chlorine, there is no satisfactory linear relationship, which indicates the function of sulfur and chlorine in fly ash is more complicated in PC Boilers.

It appears that there is a very small possibility for sulfur, chlorine and trace metal oxides to affect the mercury concentration in fly ash. However, unburned carbon and 
Table 9. Regression Analysis for $\mathrm{Hg}^{\mathrm{p}}$-Metal Oxides at the MHP.

\begin{tabular}{cccccc}
\hline Regression Predictor & R-Square & F-Statistic & Coefficient & T-ratio & P-Value \\
\hline $\mathrm{Na}_{2} \mathrm{O}$ & $4.3 \%$ & 1.12 & 0.01530 & 1.06 & 0.301 \\
$\mathrm{MgO}$ & $0.8 \%$ & 0.19 & 0.01532 & 0.44 & 0.666 \\
$\mathrm{Al}_{2} \mathrm{O}_{3}$ & $36.8 \%$ & 14.53 & -0.02777 & -3.81 & 0.001 \\
$\mathrm{SiO}_{2}$ & $0.1 \%$ & 0.03 & -0.00076 & -0.19 & 0.854 \\
$\mathrm{CaO}$ & $5.6 \%$ & 1.49 & 0.03912 & 1.22 & 0.234 \\
$\mathrm{~K}_{2} \mathrm{O}$ & $11.1 \%$ & 3.11 & 0.04193 & 1.76 & 0.091 \\
$\mathrm{SO}_{3}$ & $0.1 \%$ & 0.02 & -0.00438 & -0.14 & 0.888 \\
$\mathrm{P}_{2} \mathrm{O}_{5}$ & $15.5 \%$ & 4.59 & -0.26280 & -2.14 & 0.042 \\
$\mathrm{BaO}$ & $11.6 \%$ & 3.28 & -0.1642 & -1.81 & 0.082 \\
$\mathrm{SrO}$ & $39.9 \%$ & 16.62 & -1.22710 & -4.08 & 0 \\
$\mathrm{Fe}_{2} \mathrm{O}_{3}$ & $3.8 \%$ & 0.98 & 0.00378 & 0.99 & 0.332 \\
$\mathrm{MnO}_{2}$ & $44.2 \%$ & 19.82 & 1.56900 & 4.45 & 0 \\
$\mathrm{TiO}_{2}$ & $3.5 \%$ & 0.91 & -0.06962 & -0.95 & 0.351 \\
\hline
\end{tabular}




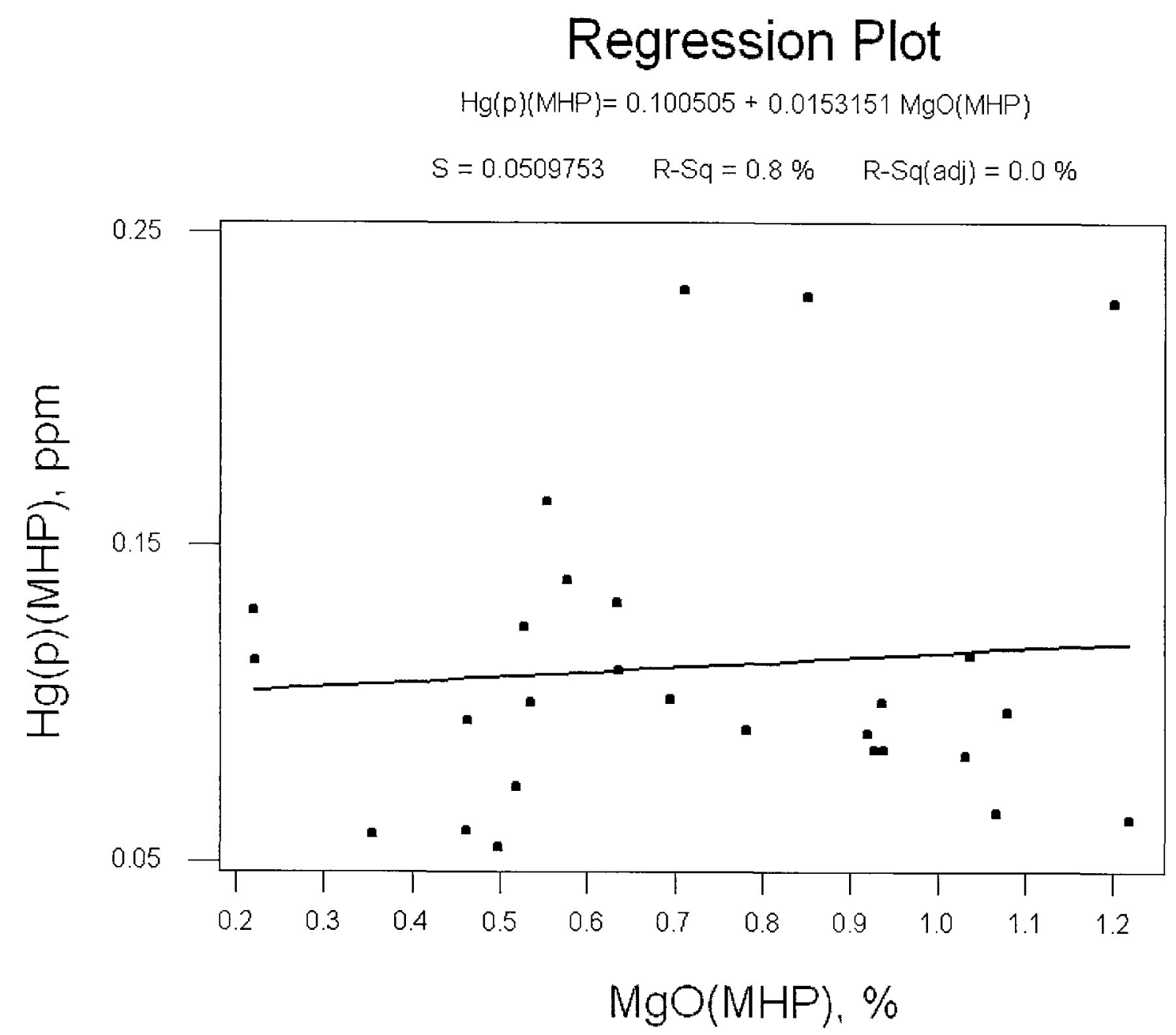

Figure 9. Regression plot of particulate mercury concentration vs. $\mathrm{MgO}$ concentration in fly ash collected from the mechanical hopper. 


\section{Regression Plot}

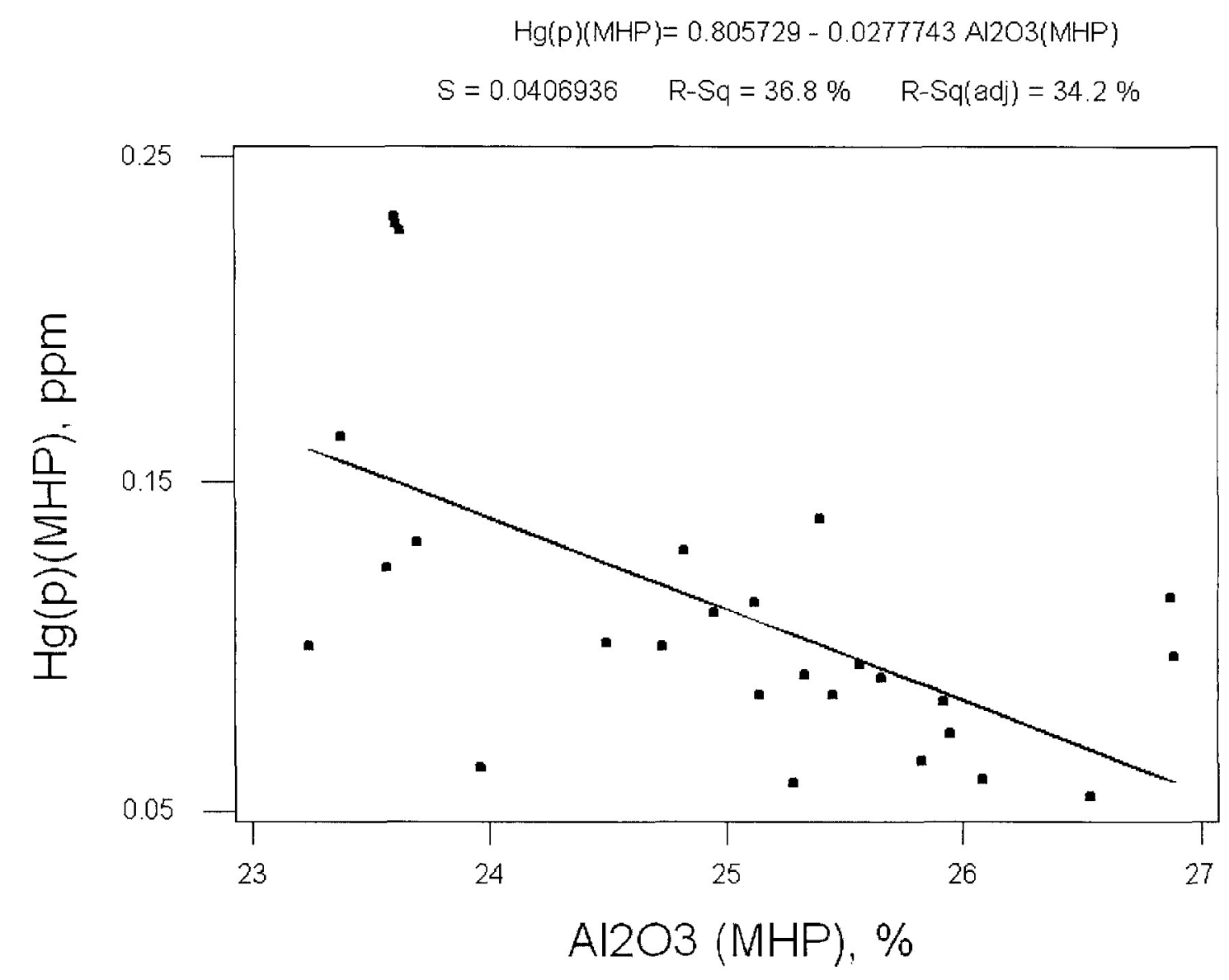

Figure 10. Regression plot of particulate mercury concentration vs. $\mathrm{Al}_{2} \mathrm{O}_{3}$ concentration in fly ash collected from the mechanical hopper. 


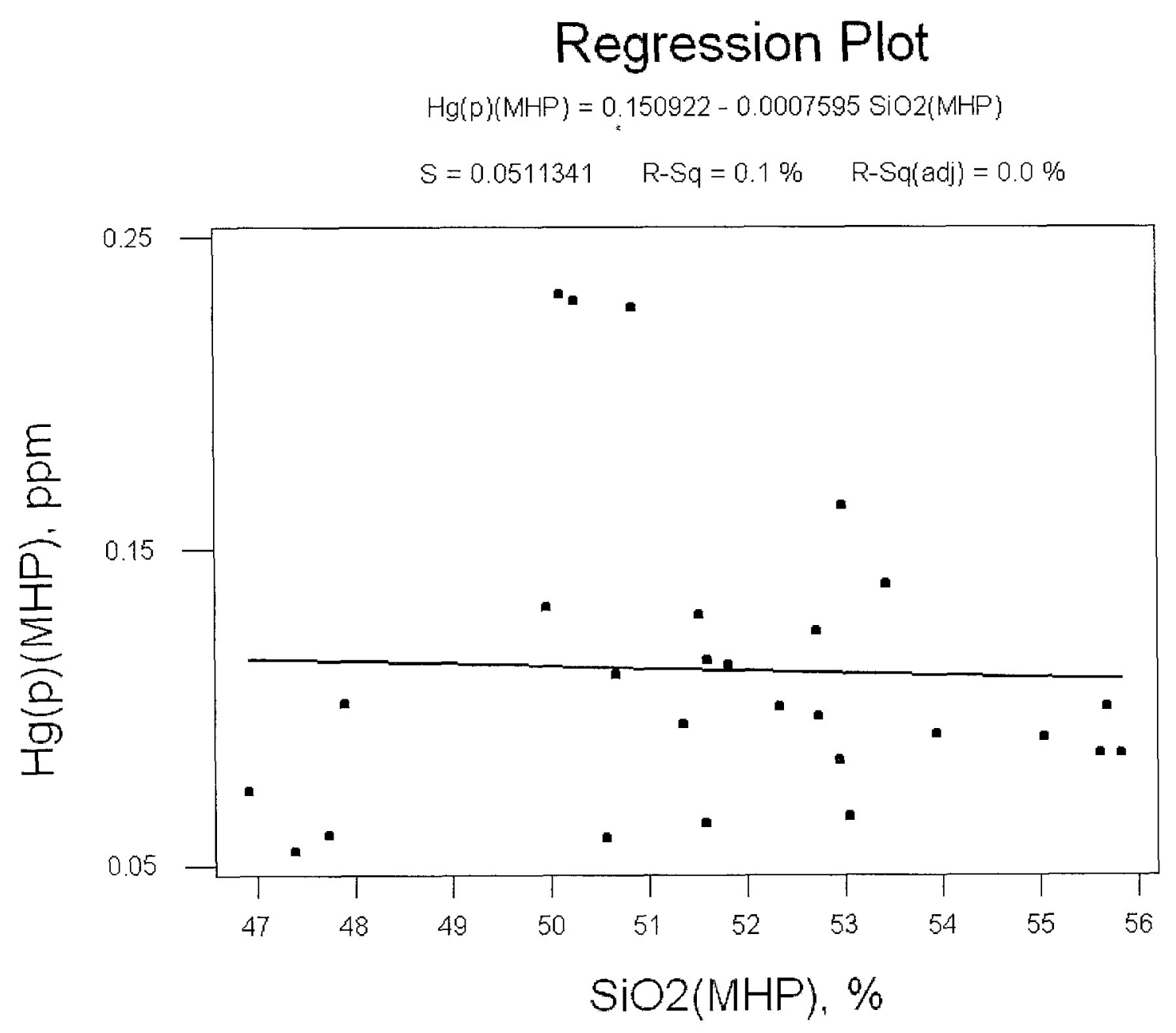

Figure 11. Regression plot of particulate mercury concentration vs. $\mathrm{SiO}_{2}$ concentration in fly ash collected from the mechanical hopper. 


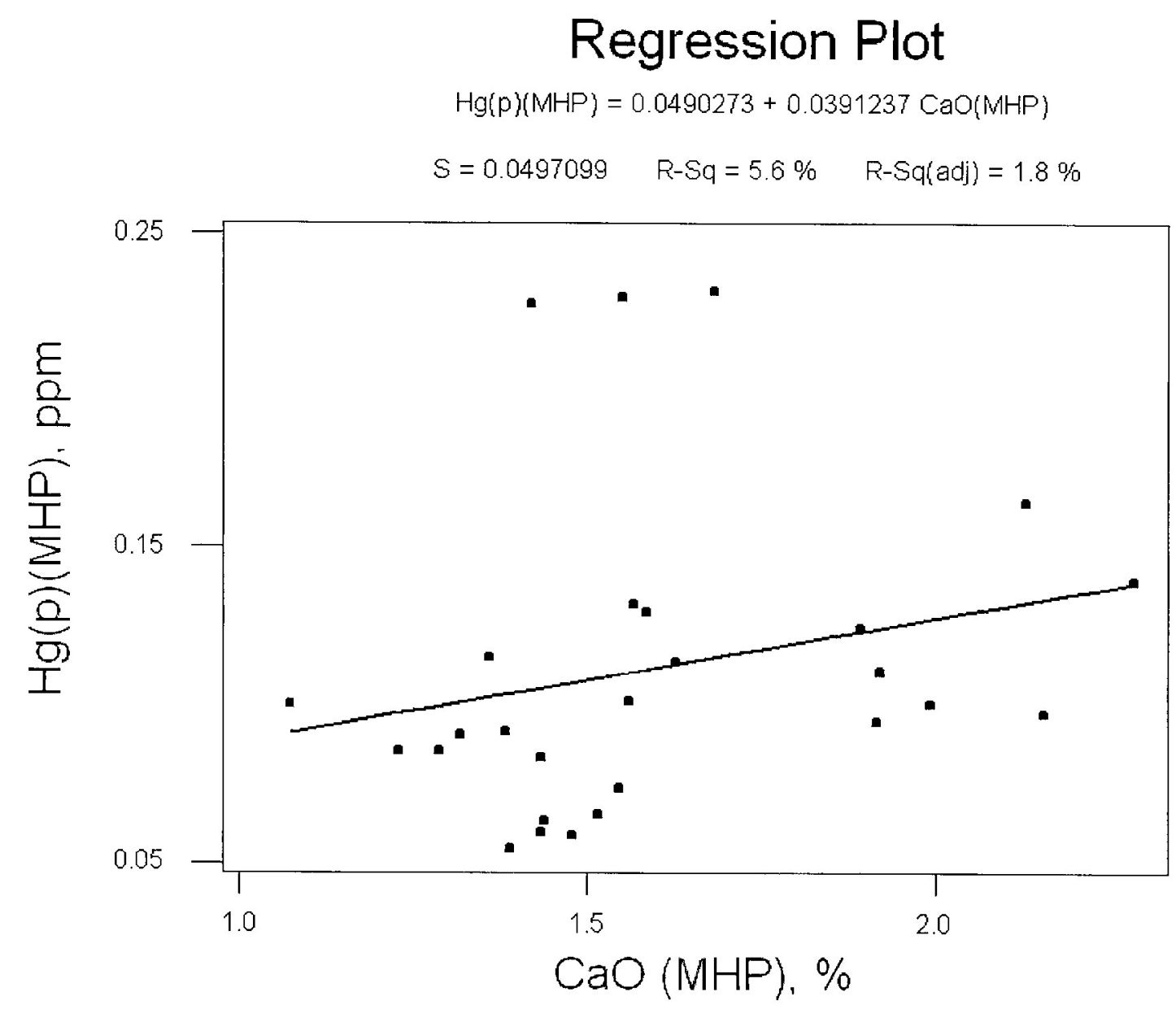

Figure 12. Regression plot of particulate mercury concentration vs. $\mathrm{CaO}$ concentration in fly ash collected from the mechanical hopper. 


\section{Regression Plot}

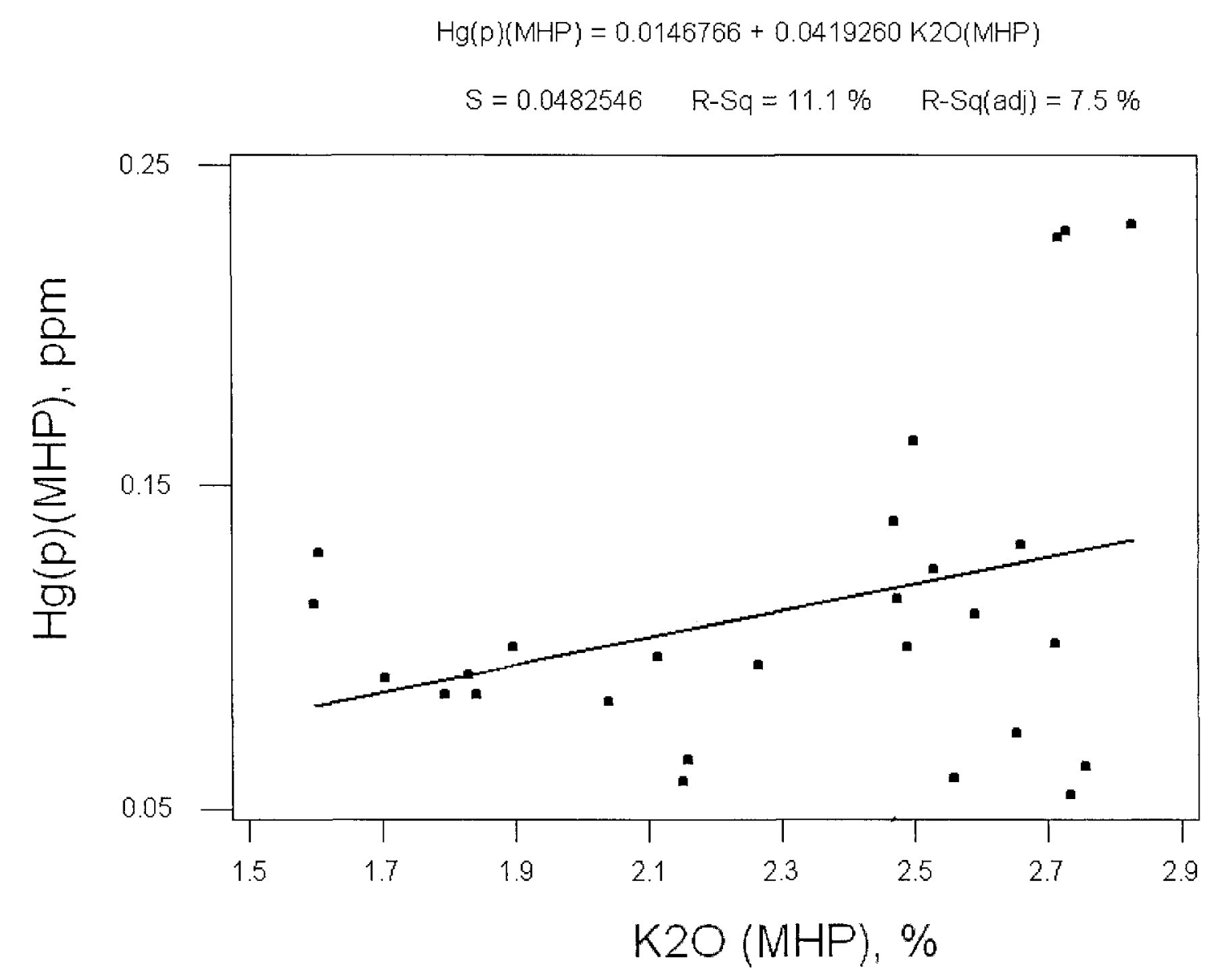

Figure 13. Regression plot of particulate mercury concentration vs. $\mathrm{K}_{2} \mathrm{O}$ concentration in fly ash collected from the mechanical hopper. 


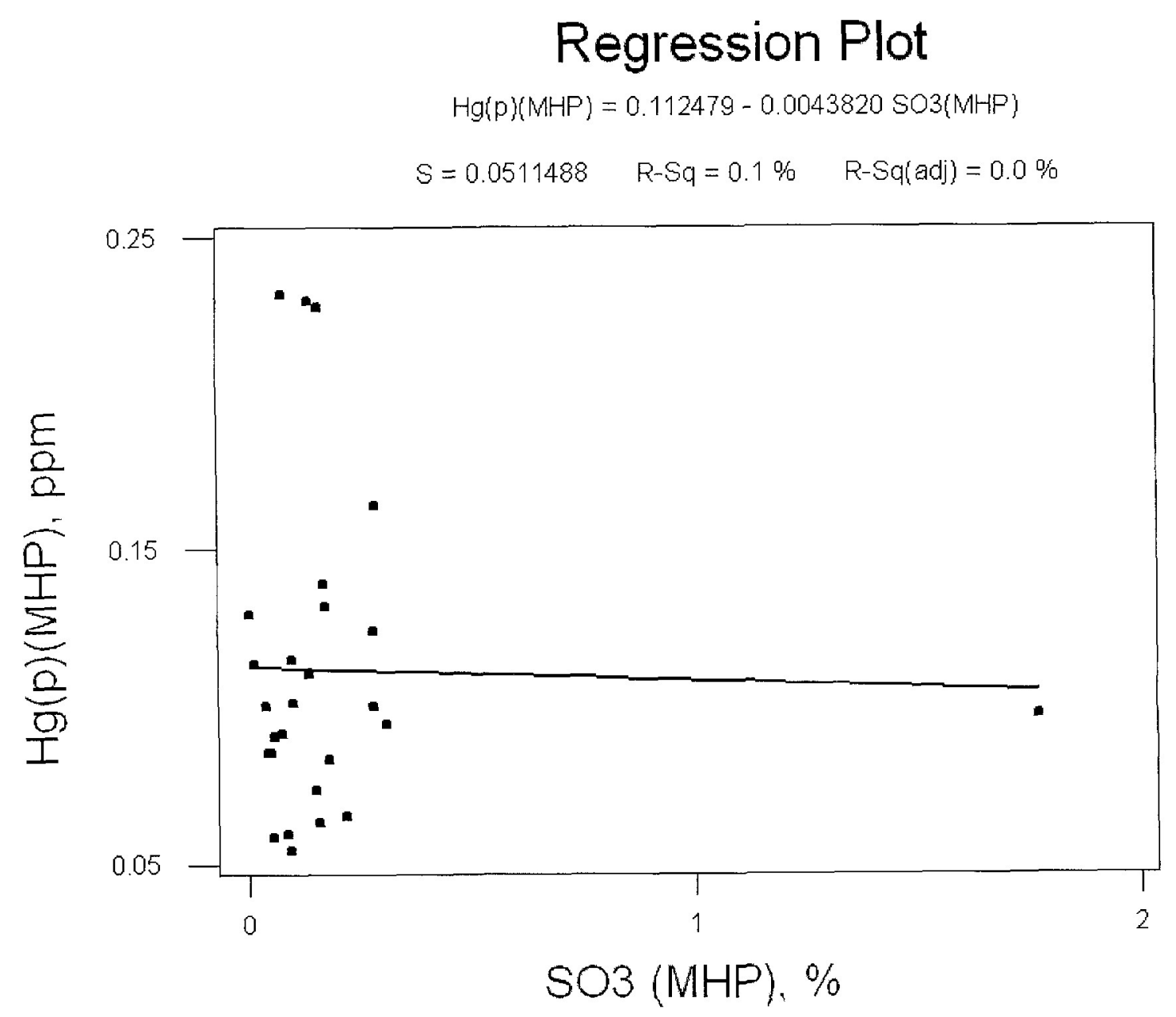

Figure 14. Regression plot of particulate mercury concentration vs. $\mathrm{SO}_{3}$ concentration in fly ash collected from the mechanical hopper. 


\section{Regression Plot}

$\mathrm{Hg}(\mathrm{p})(\mathrm{MHP})=0.171852-0.262809 \mathrm{P} 205(\mathrm{MHP})$

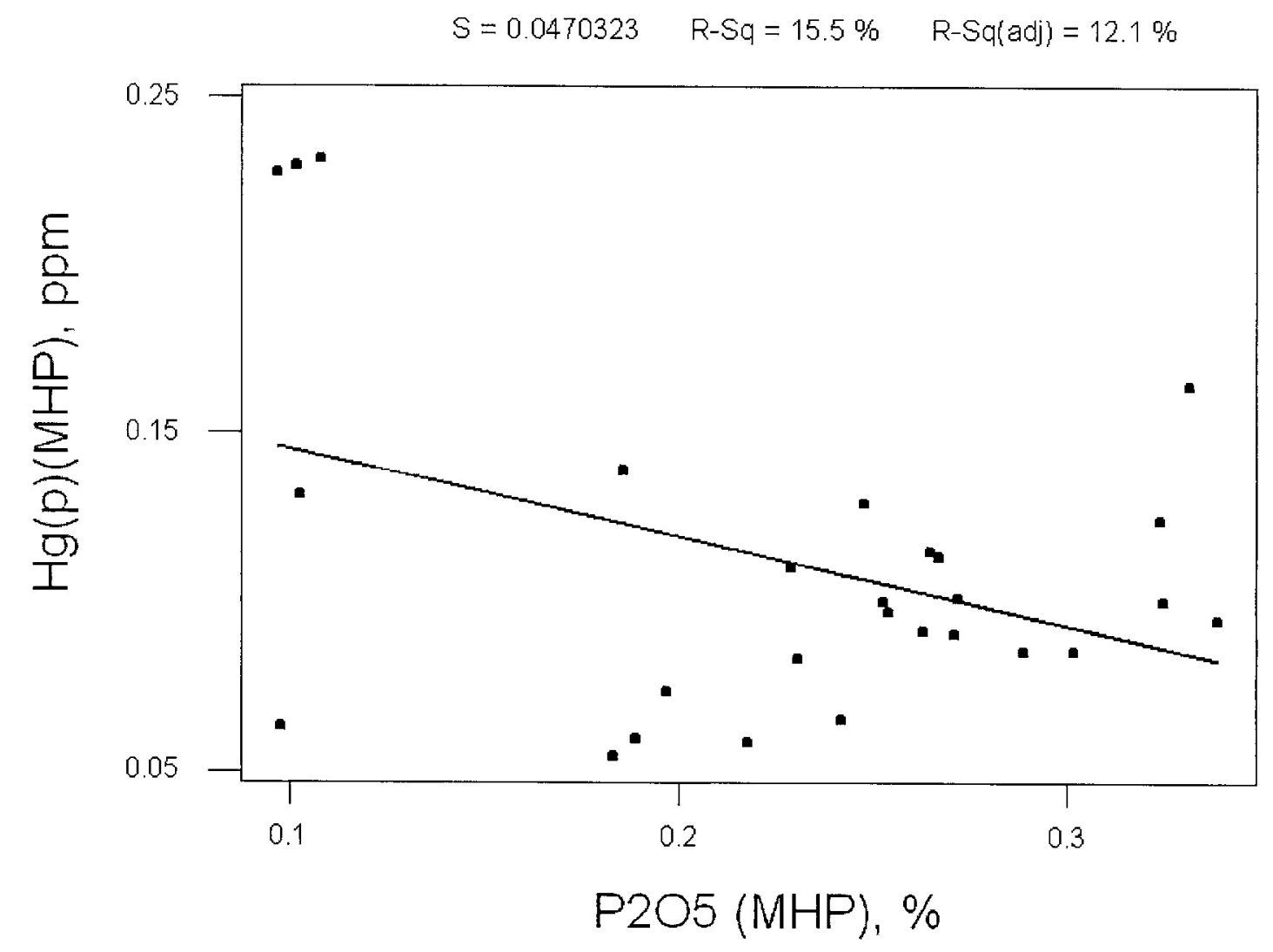

Figure 15. Regression plot of particulate mercury concentration vs. $\mathrm{P}_{2} \mathrm{O}_{5}$ concentration in fly ash collected from the mechanical hopper. 


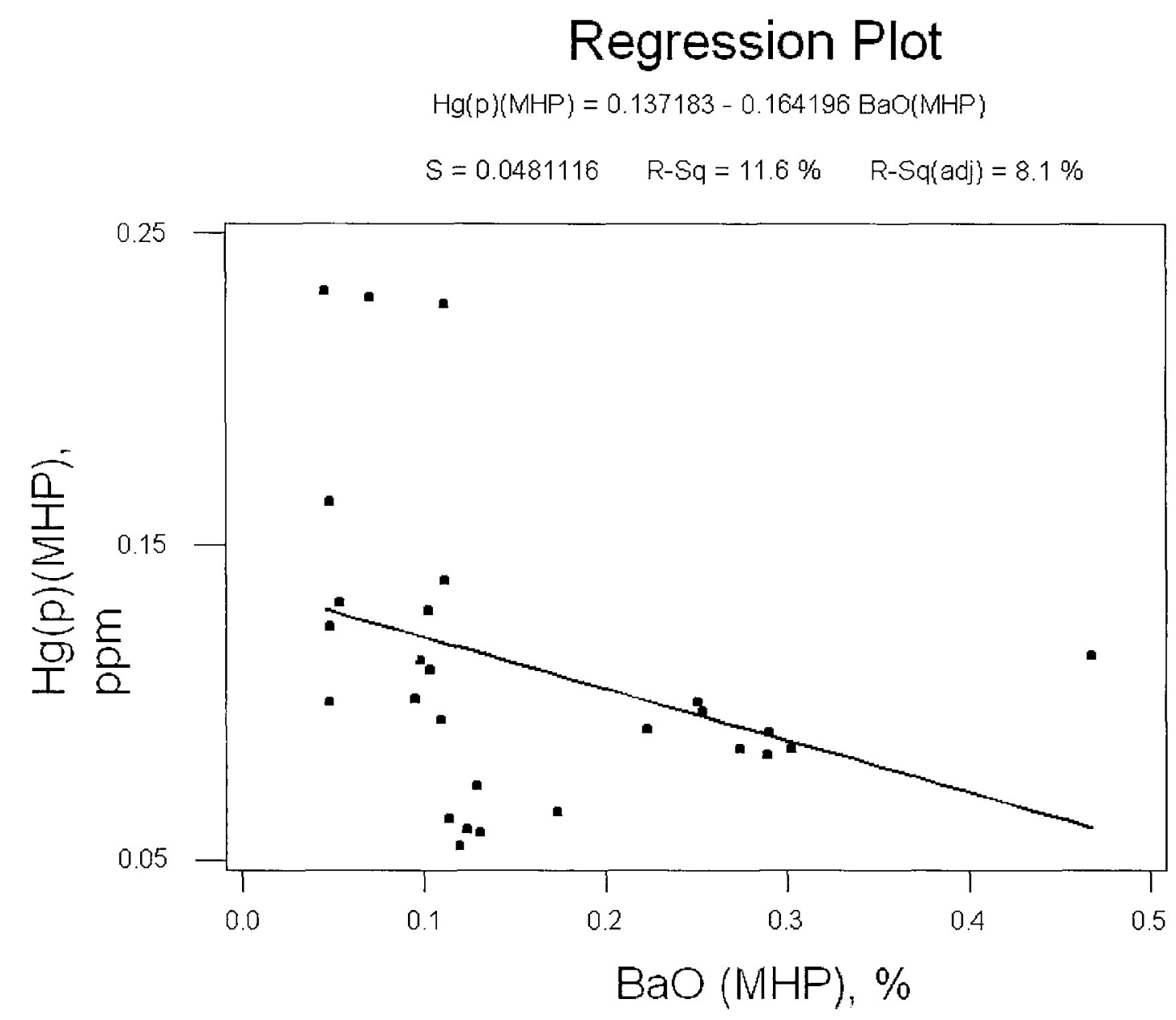

Figure 16. Regression plot of particulate mercury concentration vs. $\mathrm{BaO}$ concentration in fly ash collected from the mechanical hopper. 


\section{Regression Plot}

$\operatorname{Hg}(p)(\mathrm{MHP})=0.234202-1.22709 \operatorname{SrO}(\mathrm{MHP})$

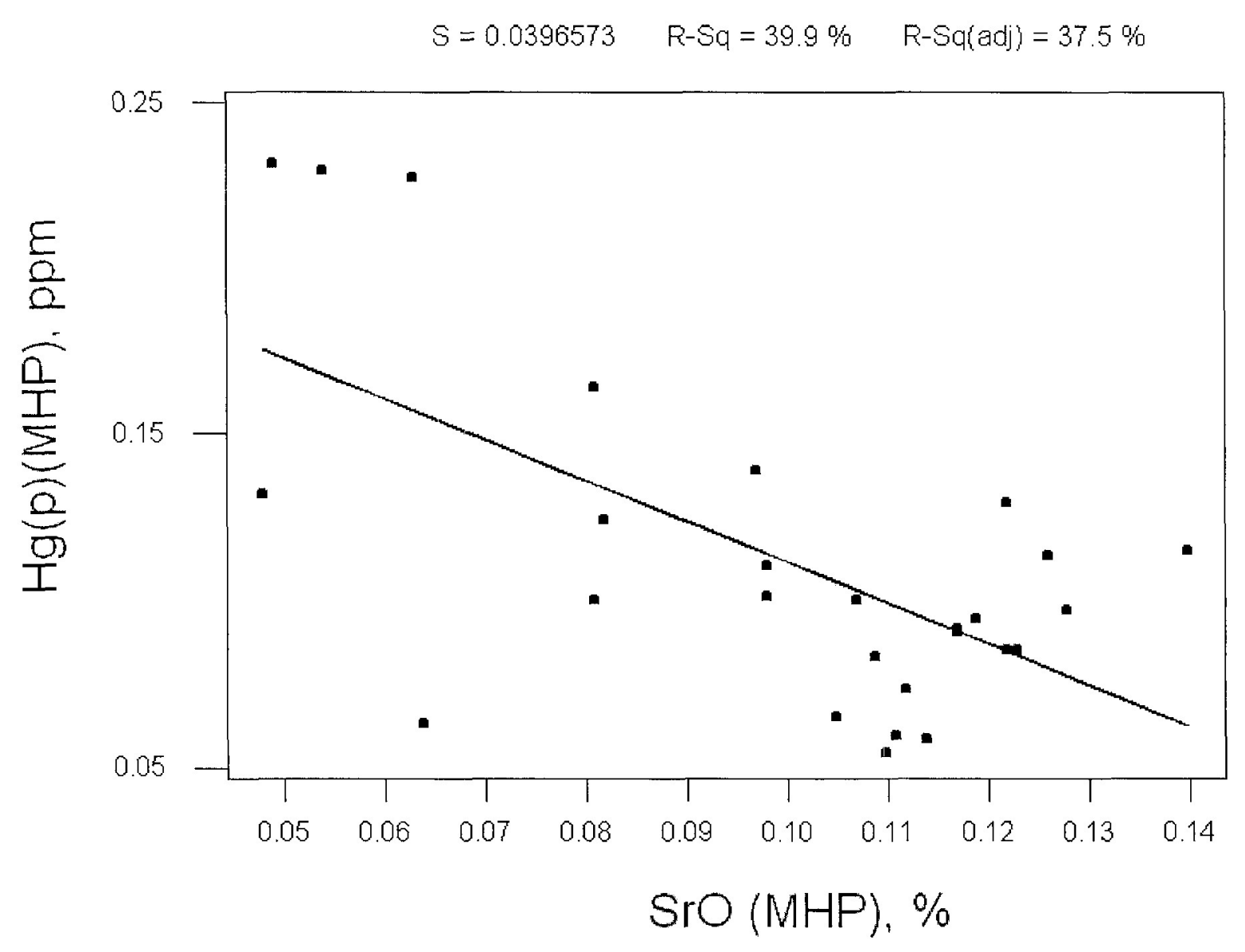

Figure 17. Regression plot of particulate mercury concentration vs. SrO concentration in fly ash collected from the mechanical hopper. 


\section{Regression Plot}

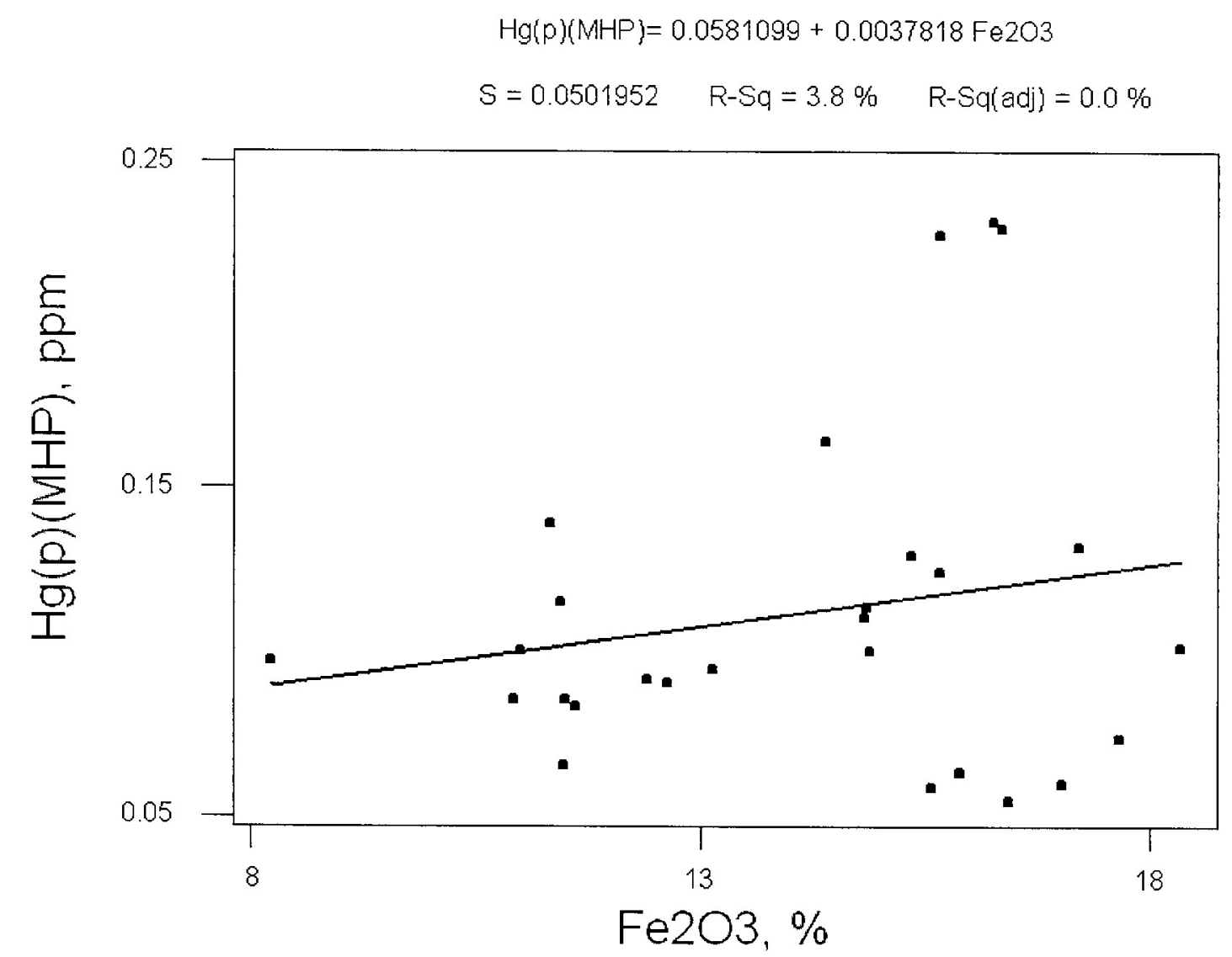

Figure 18. Regression plot of particulate mercury concentration vs. $\mathrm{Fe}_{2} \mathrm{O}_{3}$ concentration in fly ash collected from the mechanical hopper. 


\section{Regression Plot}

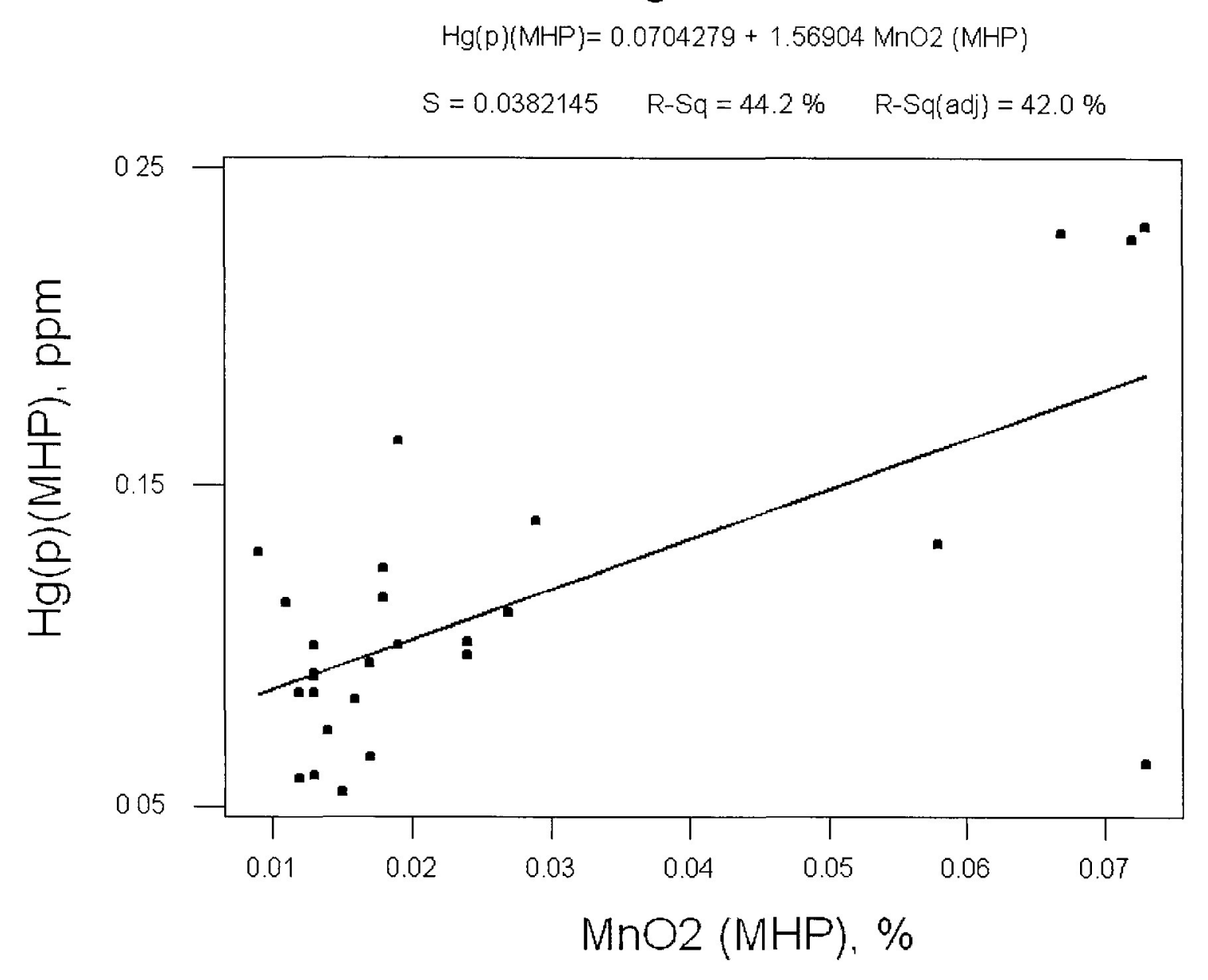

Figure 19. Regression plot of particulate mercury concentration vs. $\mathrm{MnO}_{2}$ concentration in fly ash collected from the mechanical hopper. 


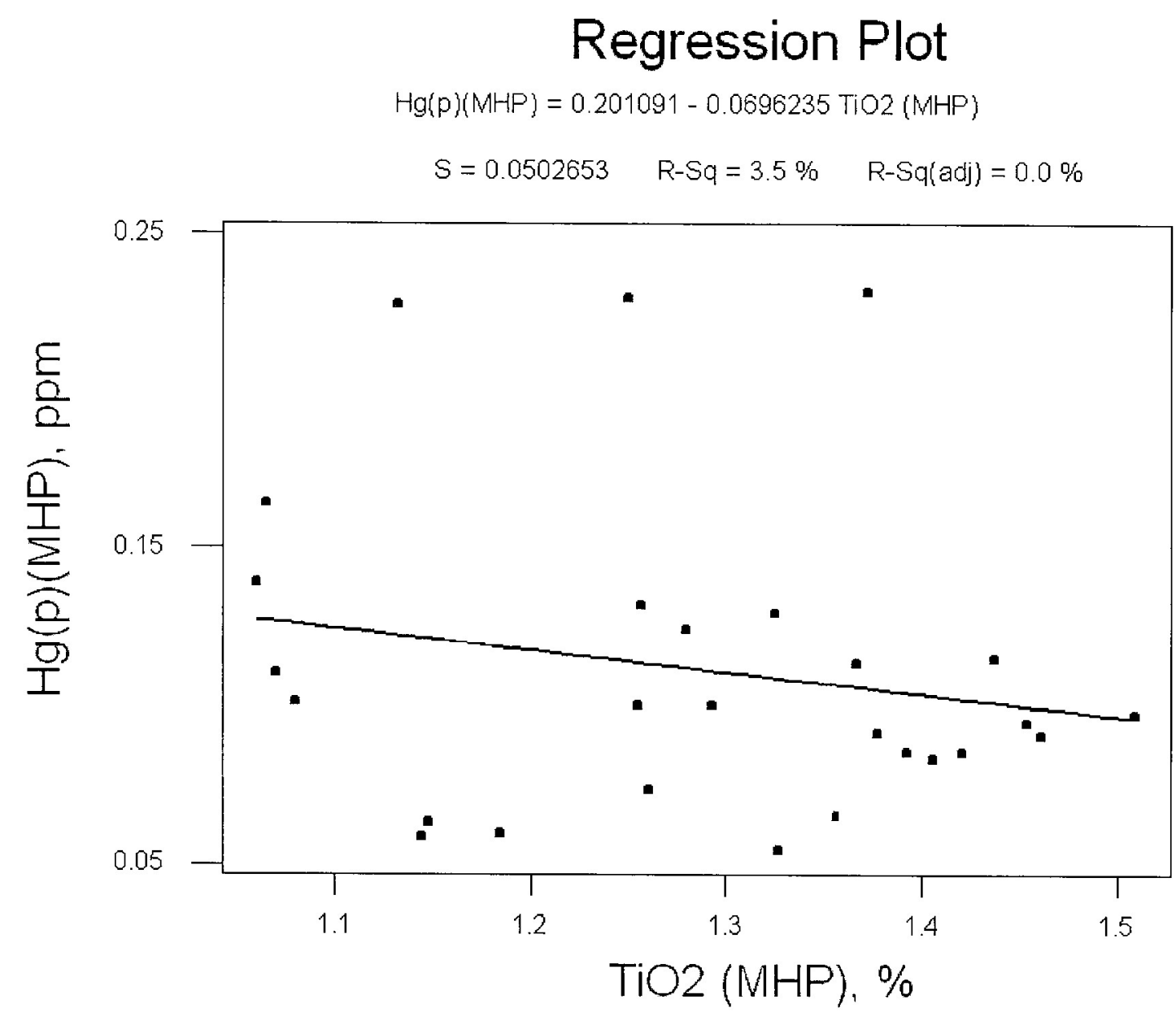

Figure 20. Regression plot of particulate mercury concentration vs. $\mathrm{TiO}_{2}$ concentration in fly ash collected from the mechanical hopper. 
Table 10. Regression Analysis for $\mathrm{Hg}^{\mathrm{p}}$-Metal Oxides at the ESP.

\begin{tabular}{cccccc}
\hline Regression Predictor & R-Square & F-Statistic & Coefficient & T-ratio & P-Value \\
\hline $\mathrm{Na}_{2} \mathrm{O}$ & $0.8 \%$ & 0.17 & 0.11370 & 0.41 & 0.686 \\
$\mathrm{MgO}$ & $0.3 \%$ & 0.07 & -0.11800 & -0.27 & 0.791 \\
$\mathrm{Al}_{2} \mathrm{O}_{3}$ & $20.9 \%$ & 5.83 & -0.11297 & -2.41 & 0.025 \\
$\mathrm{SiO}_{2}$ & $1.4 \%$ & 0.31 & -0.01067 & -0.56 & 0.582 \\
$\mathrm{CaO}$ & $0.3 \%$ & 0.06 & 0.07570 & 0.25 & 0.803 \\
$\mathrm{~K}_{2} \mathrm{O}$ & $24.7 \%$ & 7.21 & 0.26021 & 2.69 & 0.014 \\
$\mathrm{SO}_{3}$ & $1.0 \%$ & 0.22 & -0.24760 & -0.47 & 0.645 \\
$\mathrm{P}_{2} \mathrm{O}_{5}$ & $37.4 \%$ & 13.16 & -1.51000 & -3.63 & 0.001 \\
$\mathrm{BaO}$ & $18.3 \%$ & 4.93 & -1.0841 & -2.22 & 0.037 \\
$\mathrm{SrO}$ & $53.5 \%$ & 25.29 & -8.70300 & -5.03 & 0 \\
$\mathrm{Fe}_{2} \mathrm{O}_{3}$ & $7.3 \%$ & 1.73 & 0.02042 & 1.31 & 0.202 \\
$\mathrm{MnO}_{2}$ & $51.2 \%$ & 23.06 & 11.65300 & 4.8 & 0 \\
$\mathrm{TiO}_{2}$ & $24.0 \%$ & 6.93 & -0.68670 & -2.63 & 0.015 \\
\hline
\end{tabular}




\section{Regression Plot}

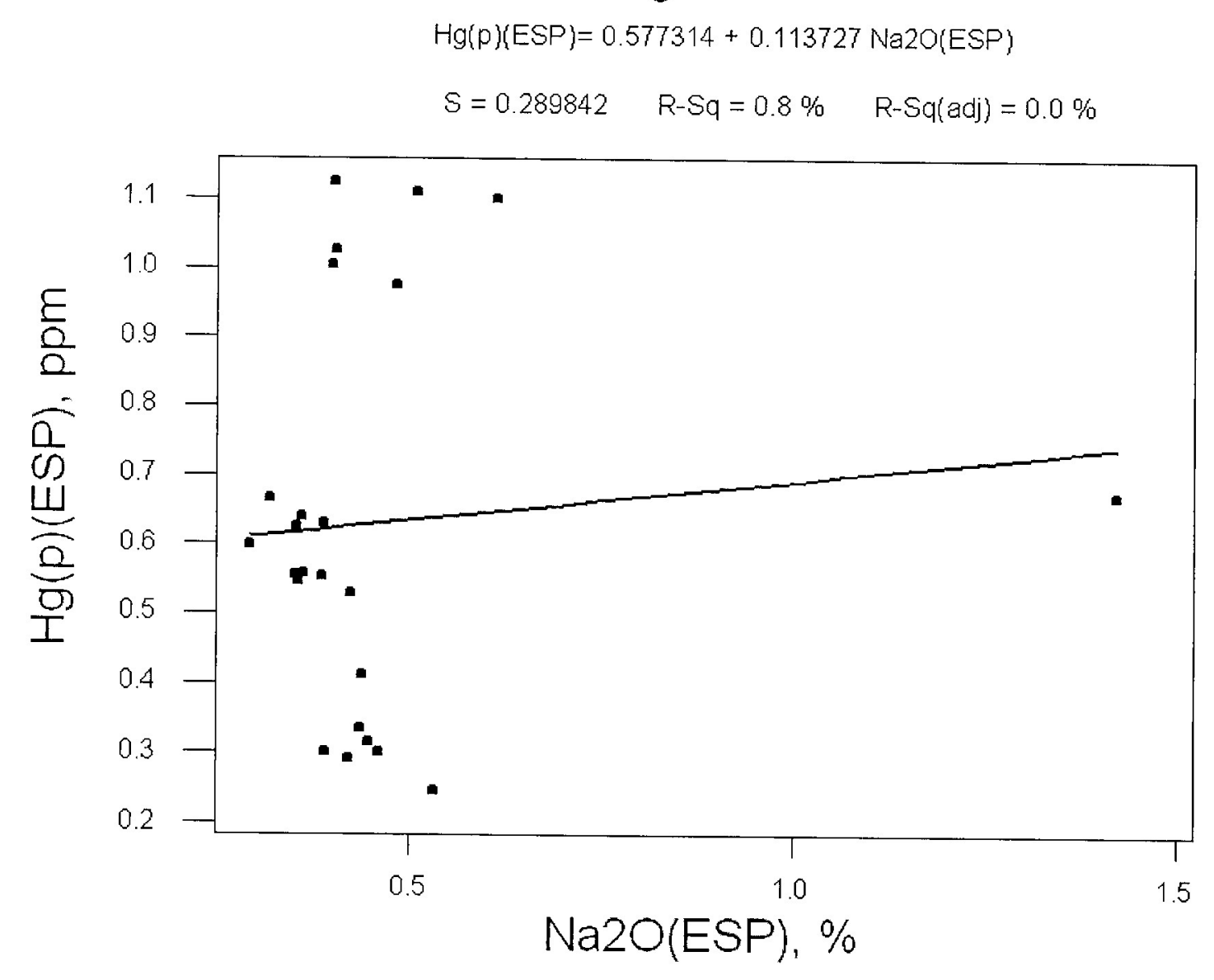

Figure 21. Regression plot of particulate mercury concentration vs. $\mathrm{Na}_{2} \mathrm{O}$ concentration in fly ash collected from the electrostatic precipitator. 


\section{Regression Plot}

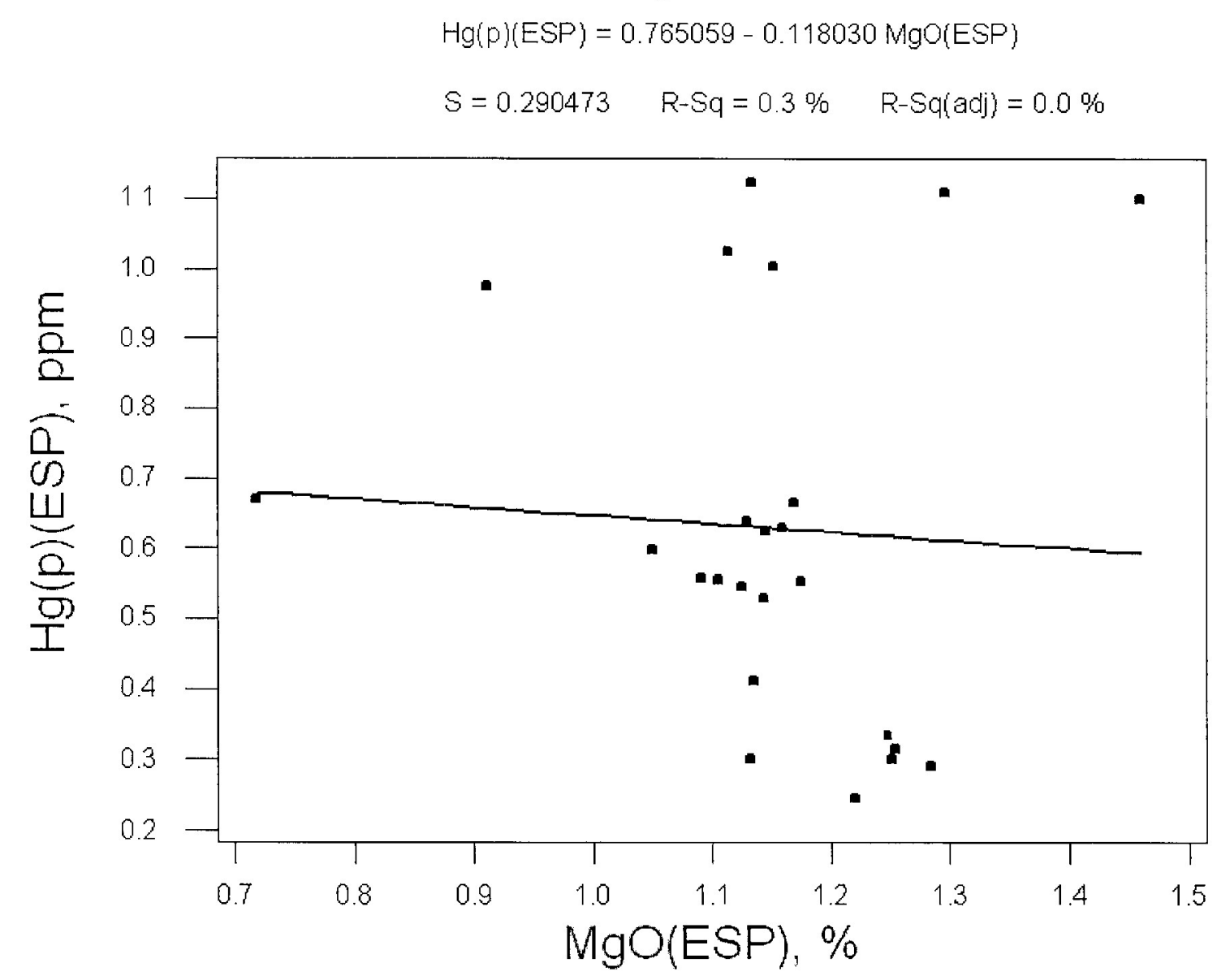

Figure 22. Regression plot of particulate mercury concentration vs. MgO concentration in fly ash collected from the electrostatic precipitator. 


\section{Regression Plot}

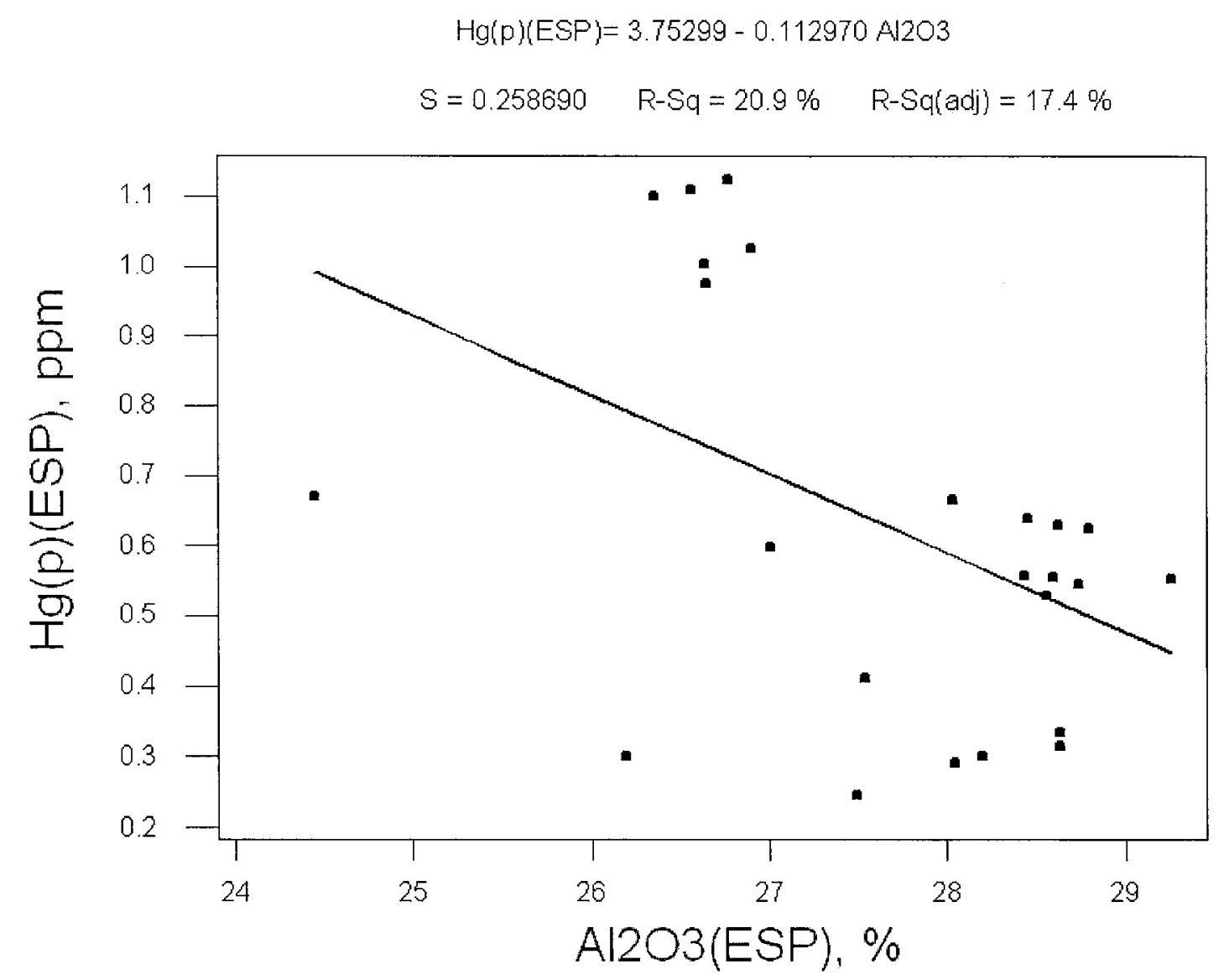

Figure 23. Regression plot of particulate mercury concentration vs. $\mathrm{Al}_{2} \mathrm{O}_{3}$ concentration in fly ash collected from the electrostatic precipitator. 


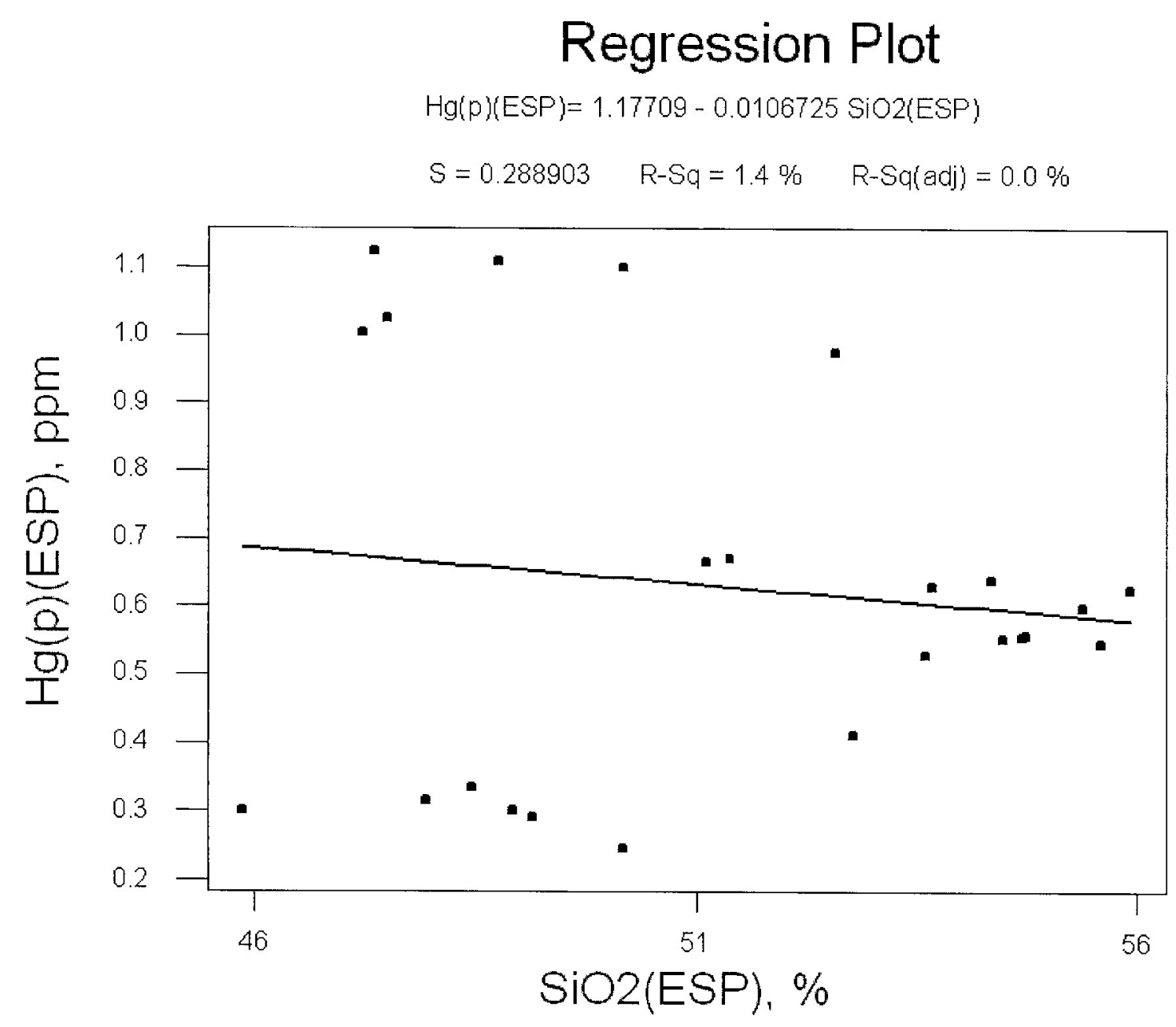

Figure 24. Regression plot of particulate mercury concentration vs. $\mathrm{SiO}_{2}$ concentration in fly ash collected from the electrostatic precipitator. 


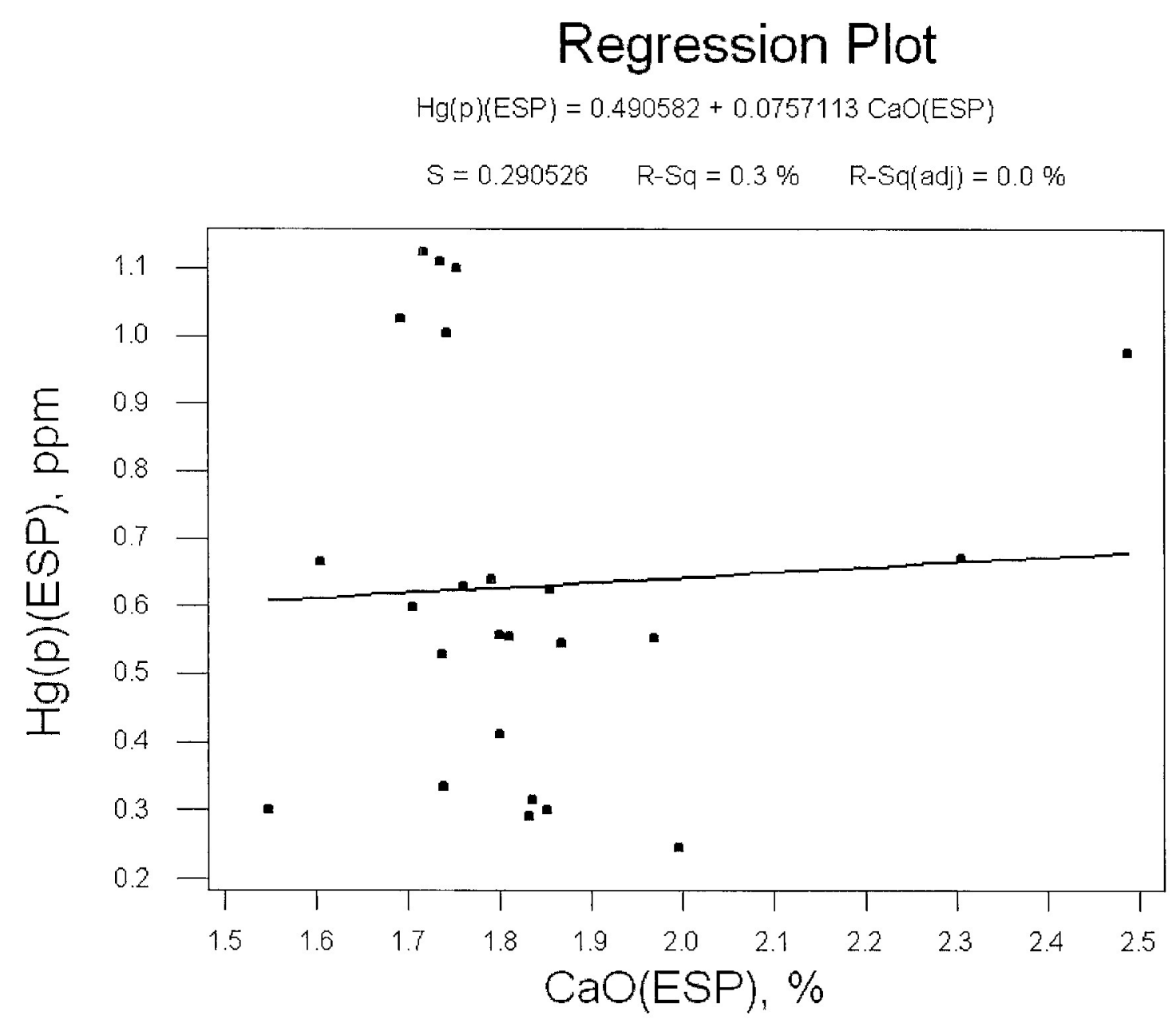

Figure 25. Regression plot of particulate mercury concentration vs. $\mathrm{CaO}$ concentration in fly ash collected from the electrostatic precipitator. 


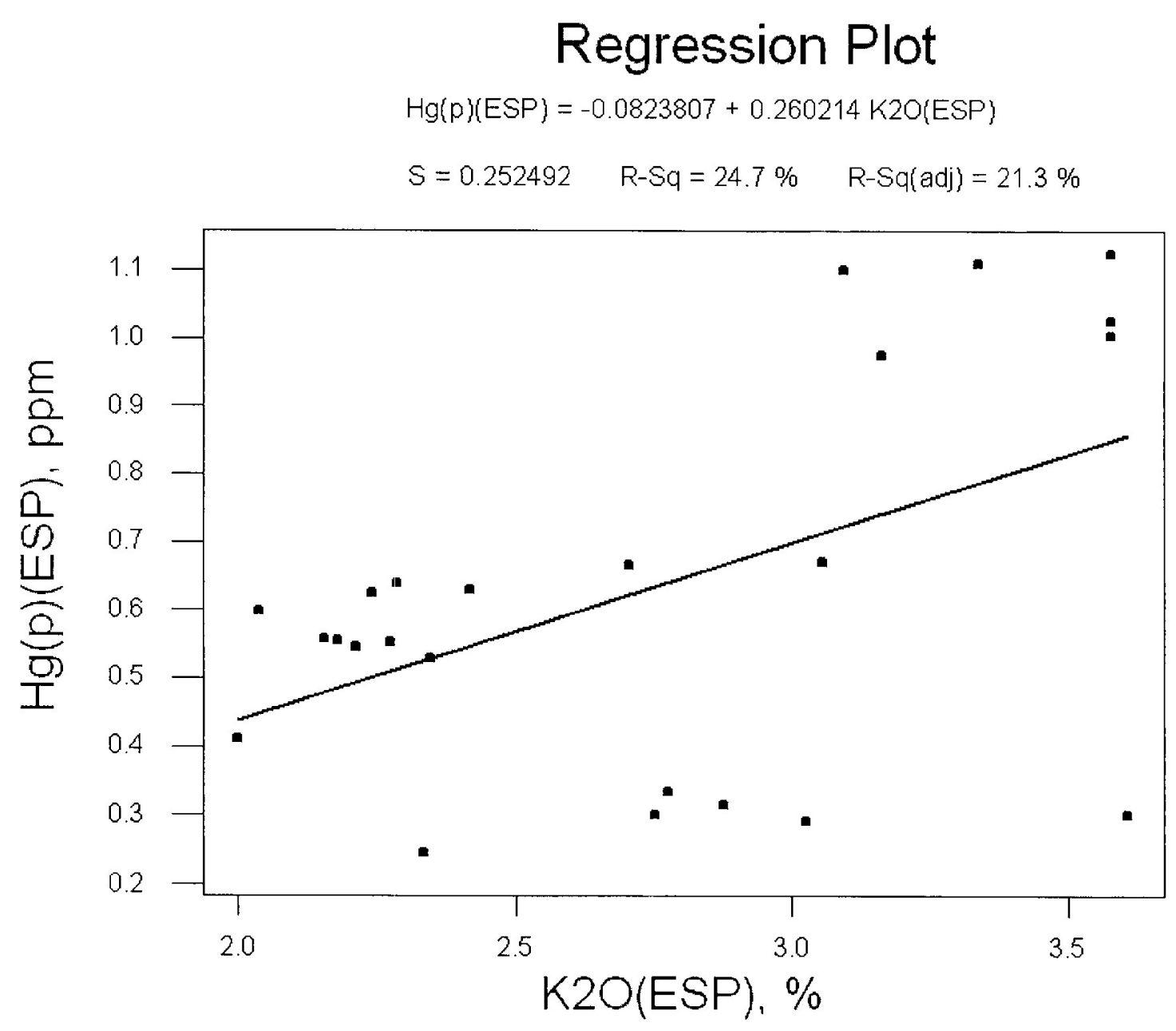

Figure 26. Regression plot of particulate mercury concentration vs. $\mathrm{K}_{2} \mathrm{O}$ concentration in fly ash collected from the electrostatic precipitator. 


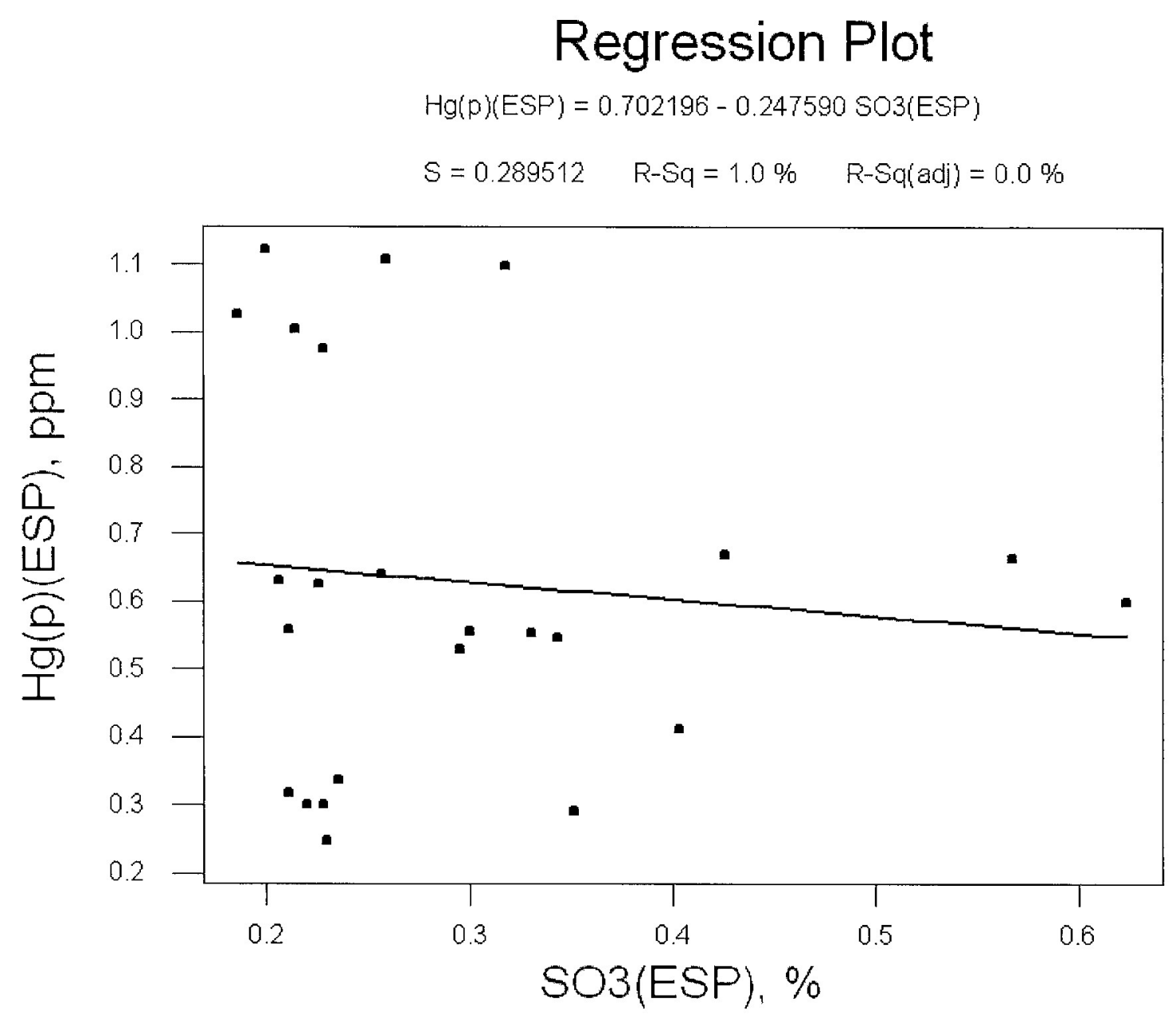

Figure 27. Regression plot of particulate mercury concentration vs. $\mathrm{SO}_{3}$ concentration in fly ash collected from the electrostatic precipitator. 


\section{Regression Plot}

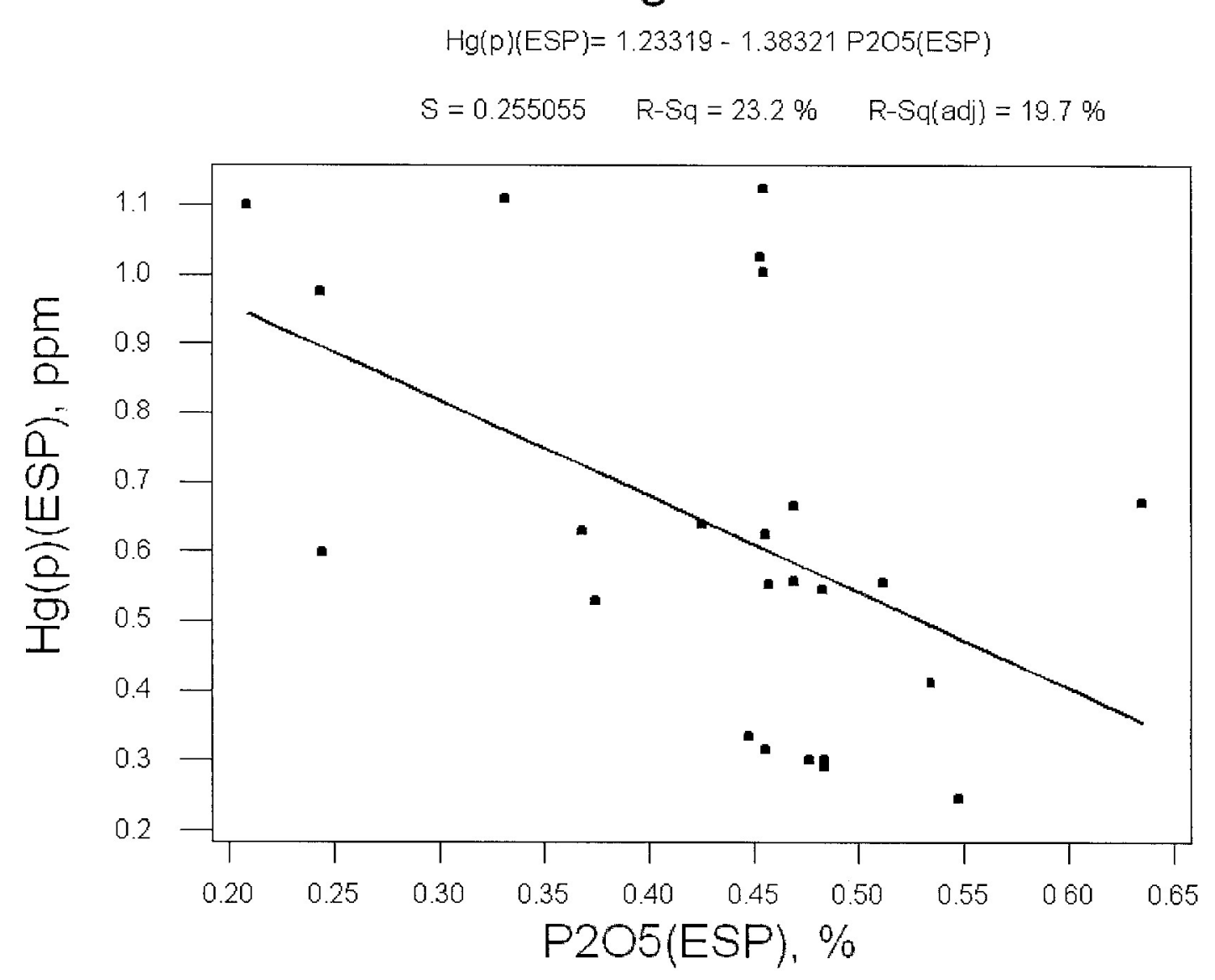

Figure 28. Regression plot of particulate mercury concentration vs. $\mathrm{P}_{2} \mathrm{O}_{5}$ concentration in fly ash collected from the electrostatic precipitator. 


\section{Regression Plot}

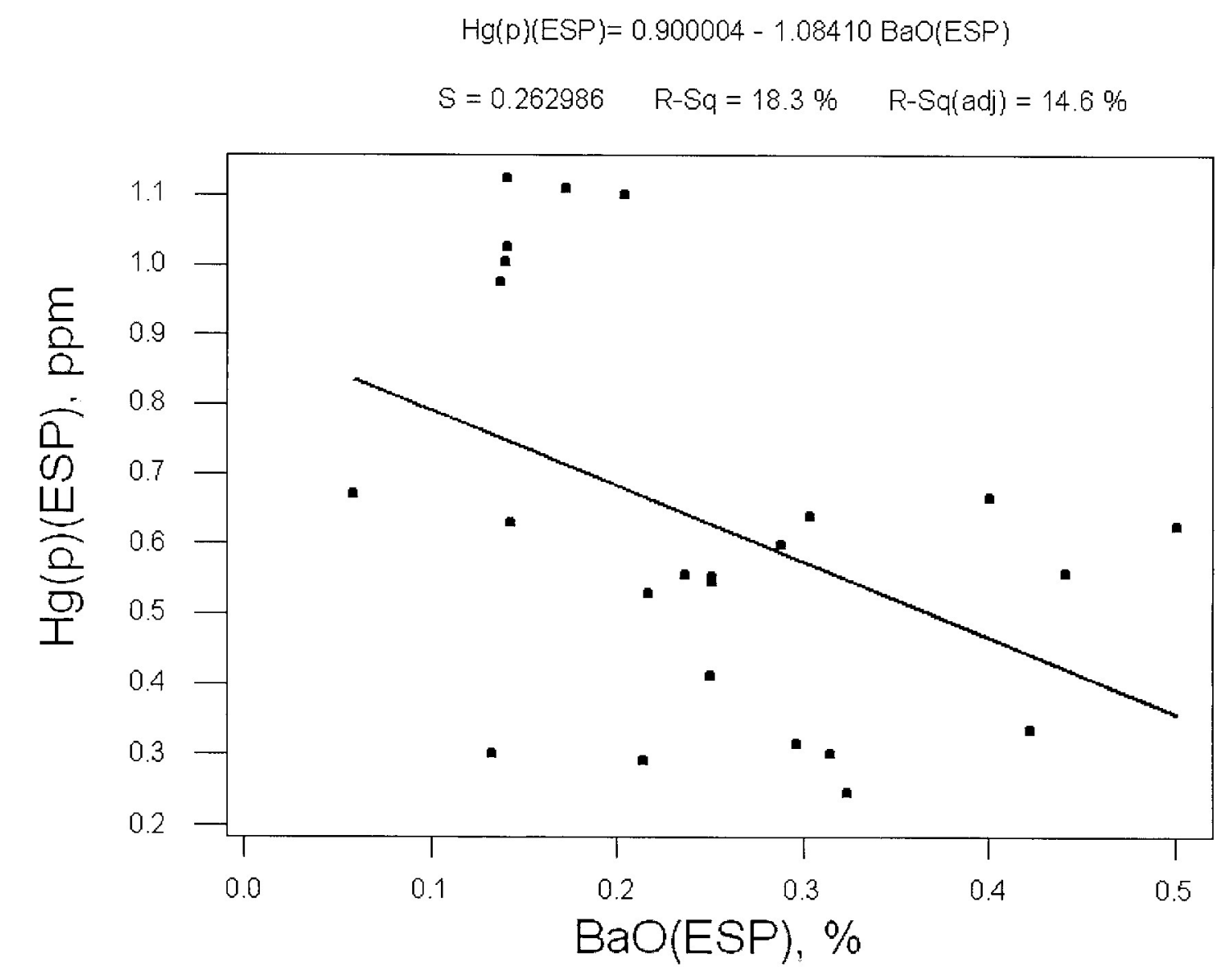

Figure 29. Regression plot of particulate mercury concentration vs. BaO concentration in fly ash collected from the electrostatic precipitator. 


\section{Regression Plot}

$H g(p)(E S P)=1.73669-8.70286$ SrO(ESP $\}$

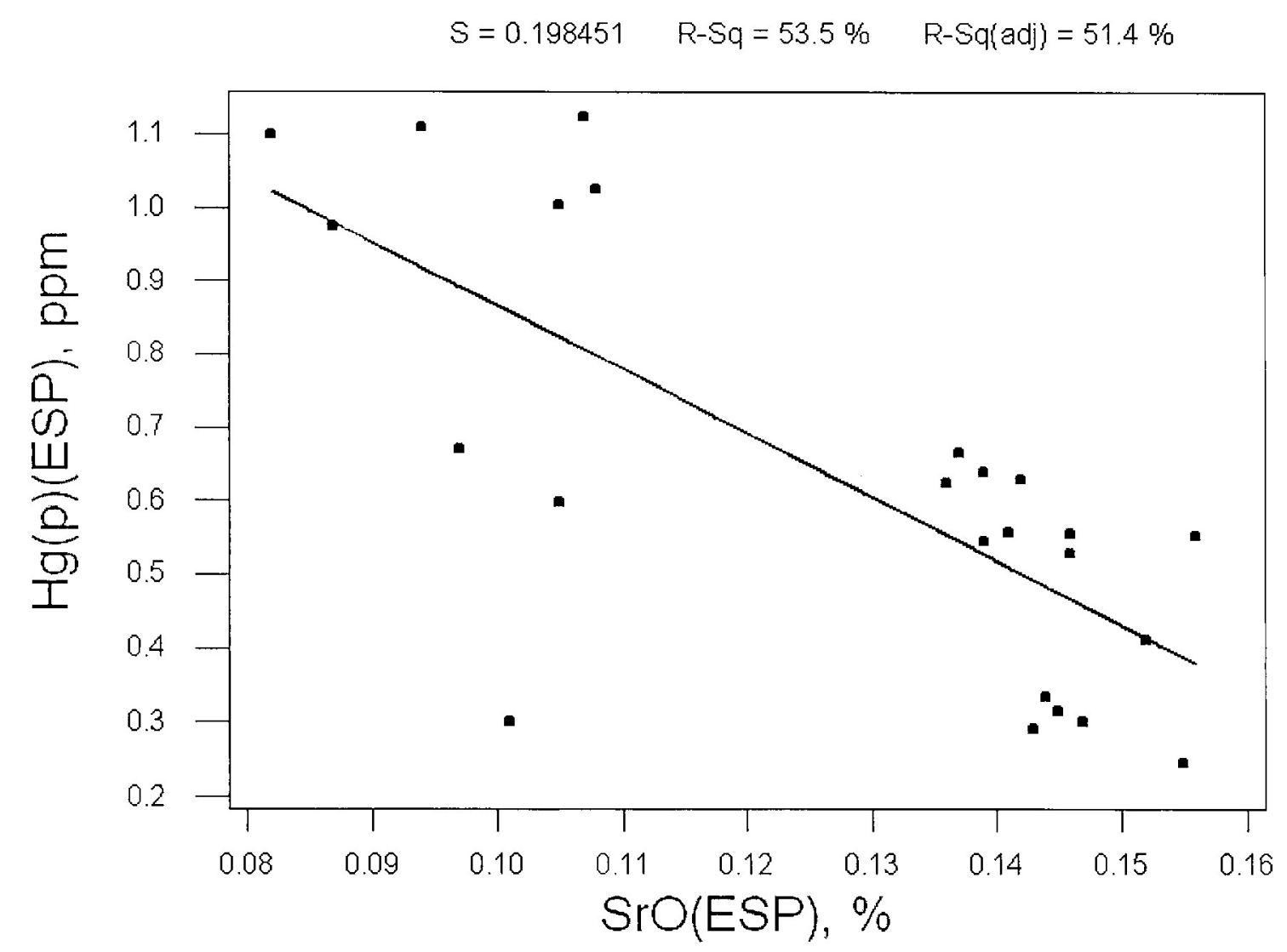

Figure 30. Regression plot of particulate mercury concentration vs. SrO concentration in fly ash collected from the electrostatic precipitator. 


\section{Regression Plot}

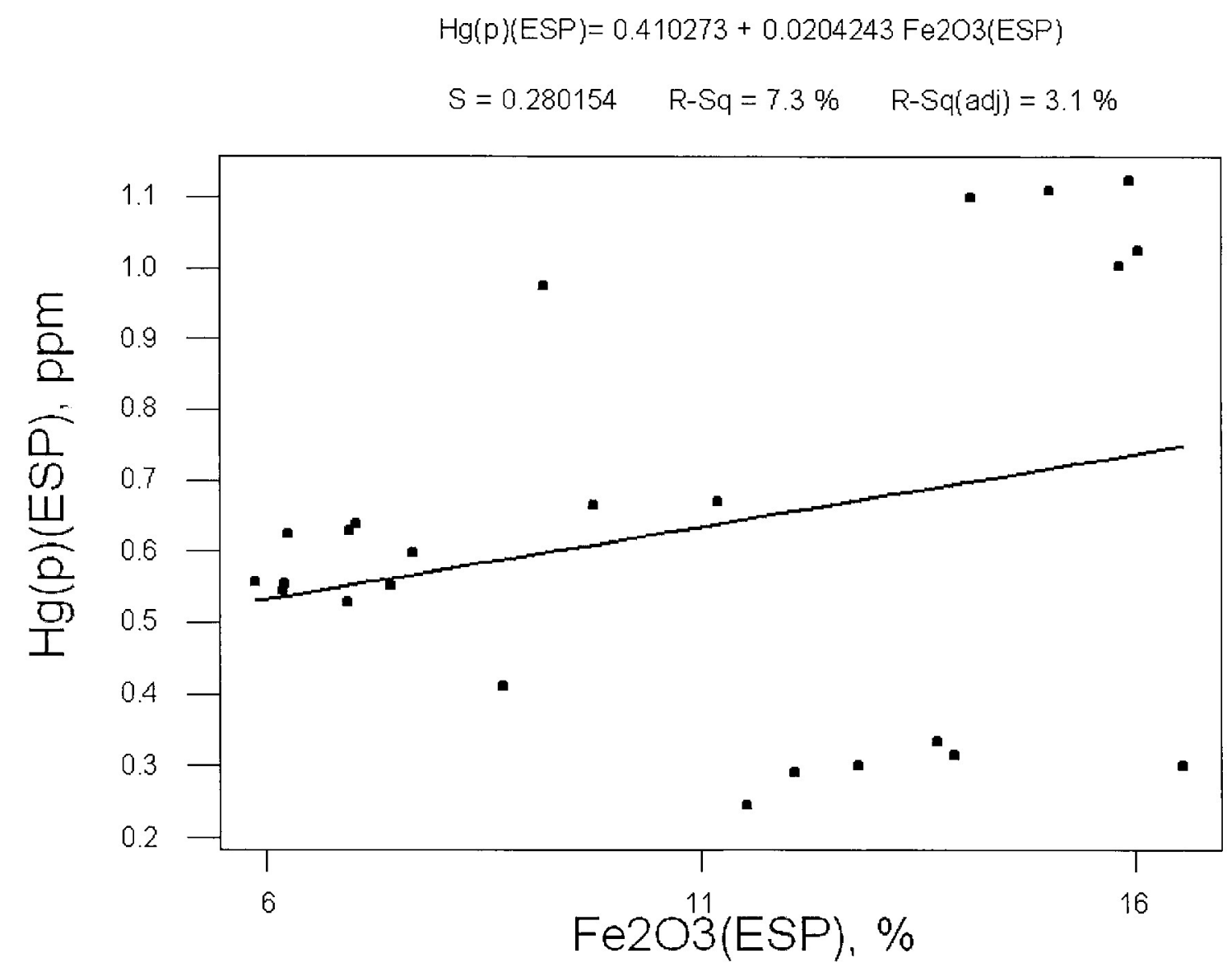

Figure 31. Regression plot of particulate mercury concentration vs. $\mathrm{Fe}_{2} \mathrm{O}_{3}$ concentration in fly ash collected from the electrostatic precipitator. 


\title{
Regression Plot
}

\author{
$\mathrm{Hg}(p)(E S P)=0.318978+11.6534 \mathrm{MnO} 2(\mathrm{ESP})$ \\ $S=0.203300 \quad R-S q=51.2 \% \quad R-S q(a d j)=49.0 \%$
}

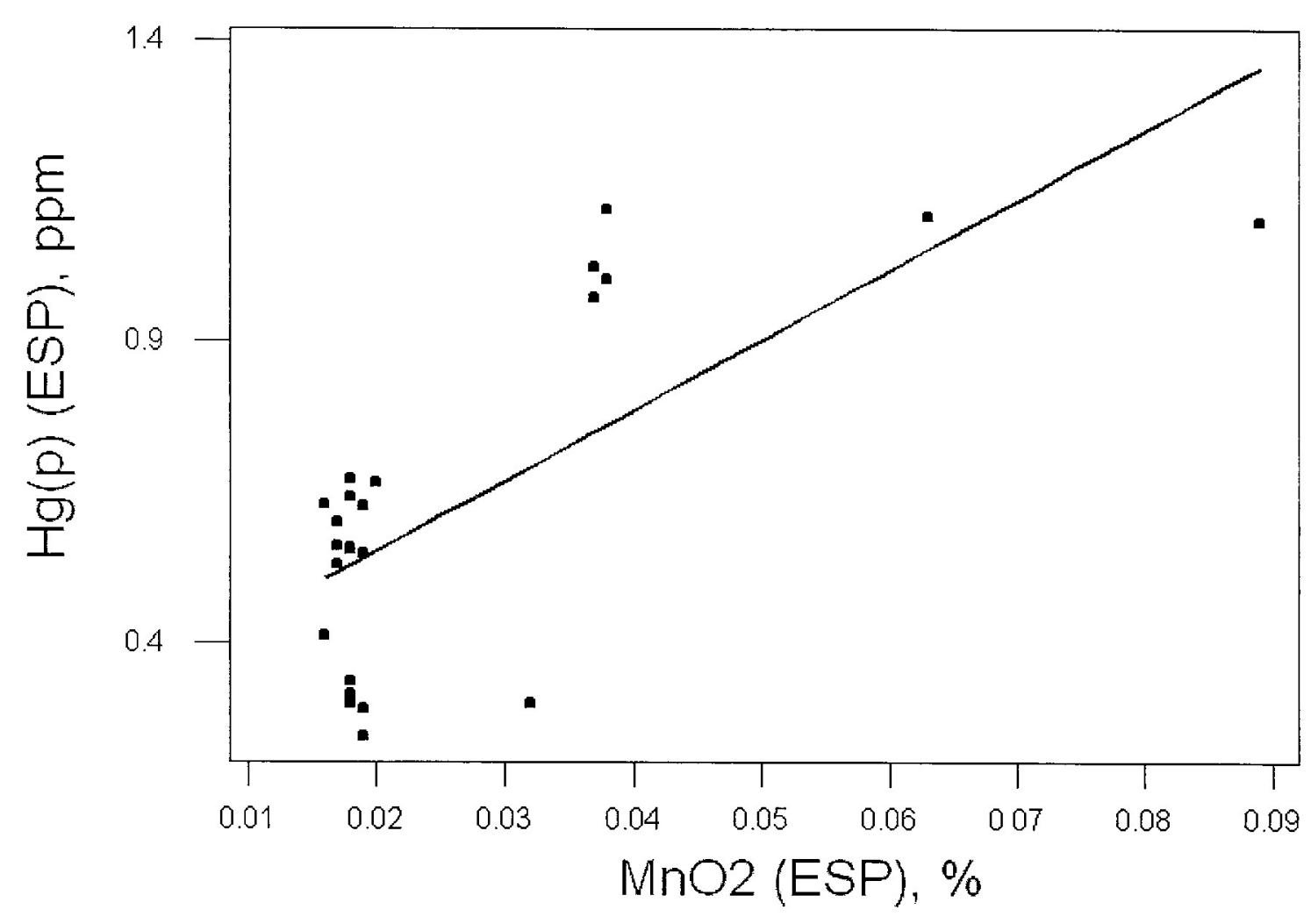

Figure 32. Regression plot of particulate mercury concentration vs. $\mathrm{MnO}_{2}$ concentration in fly ash collected from the electrostatic precipitator. 


\section{Regression Plot}

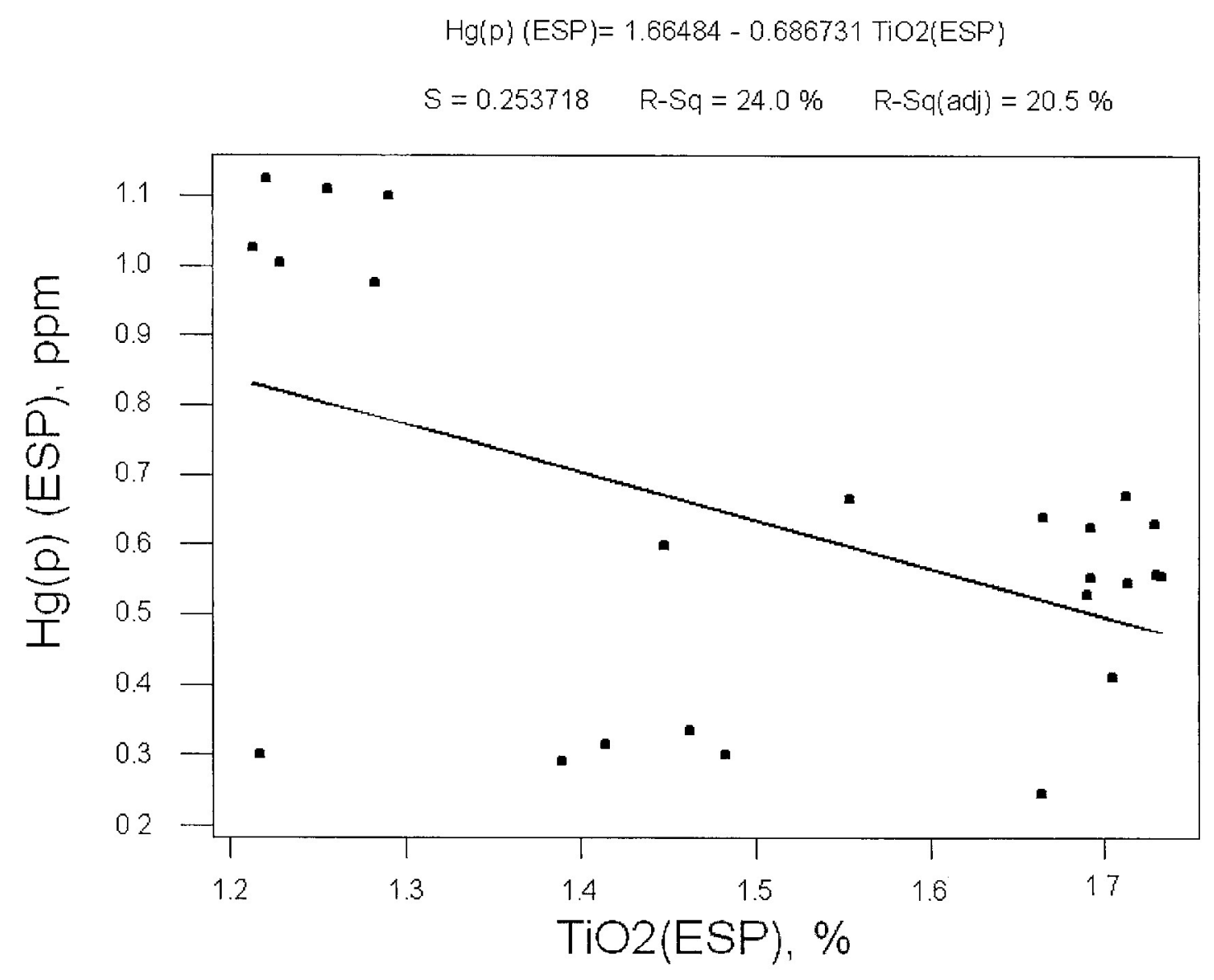

Figure 33. Regression plot of particulate mercury concentration vs. $\mathrm{TiO}_{2}$ concentration in fly ash collected from the electrostatic precipitator. 


\section{Regression Plot}

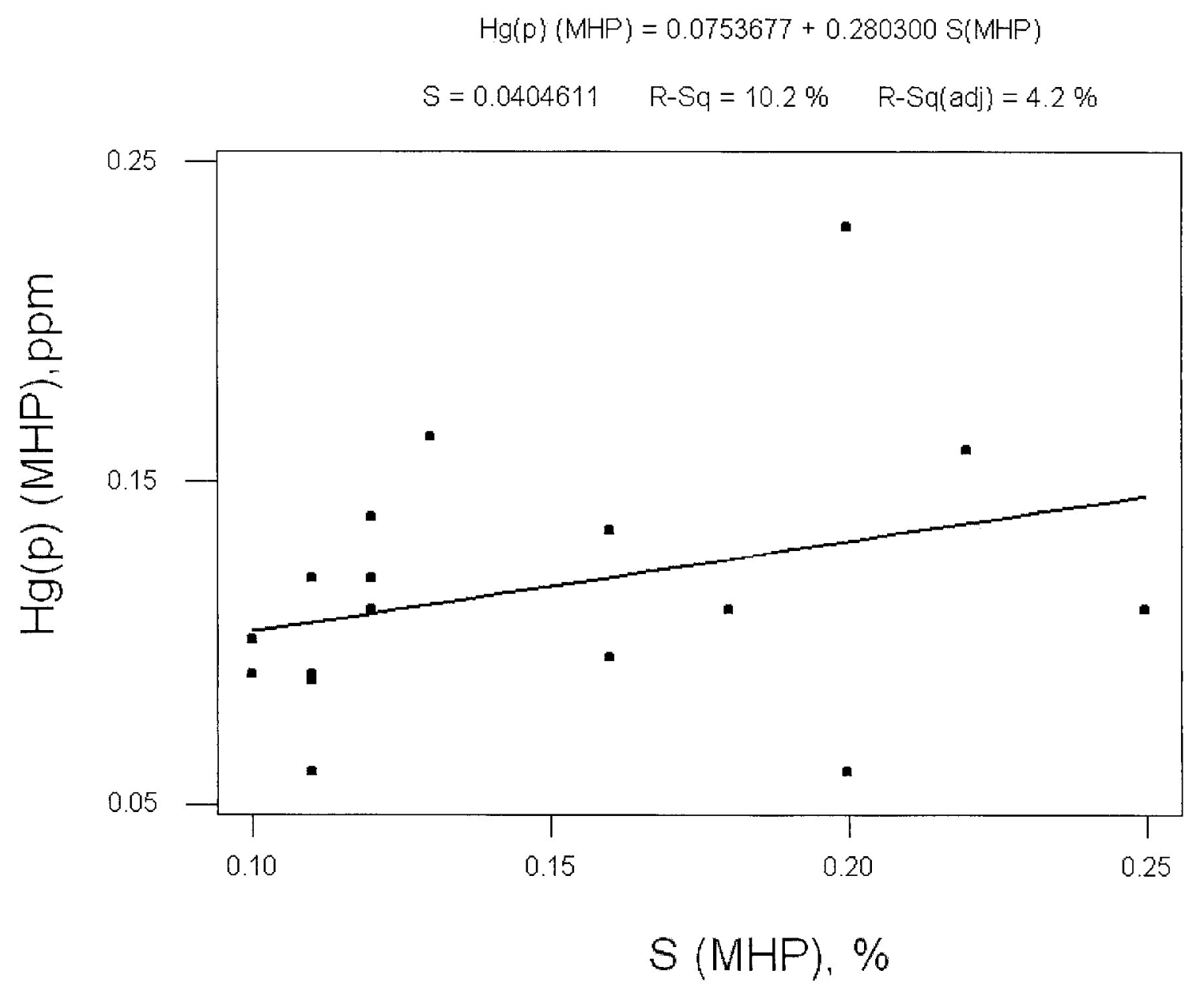

Figure 34. Regression plot of particulate mercury concentration vs. sulfur concentration in fly ash collected from the mechanical hopper. 


\section{Regression Plot}

$\mathrm{Hg}(p)(M H P)=0.116689-0.0000004 \mathrm{Cl}(\mathrm{MHP})$

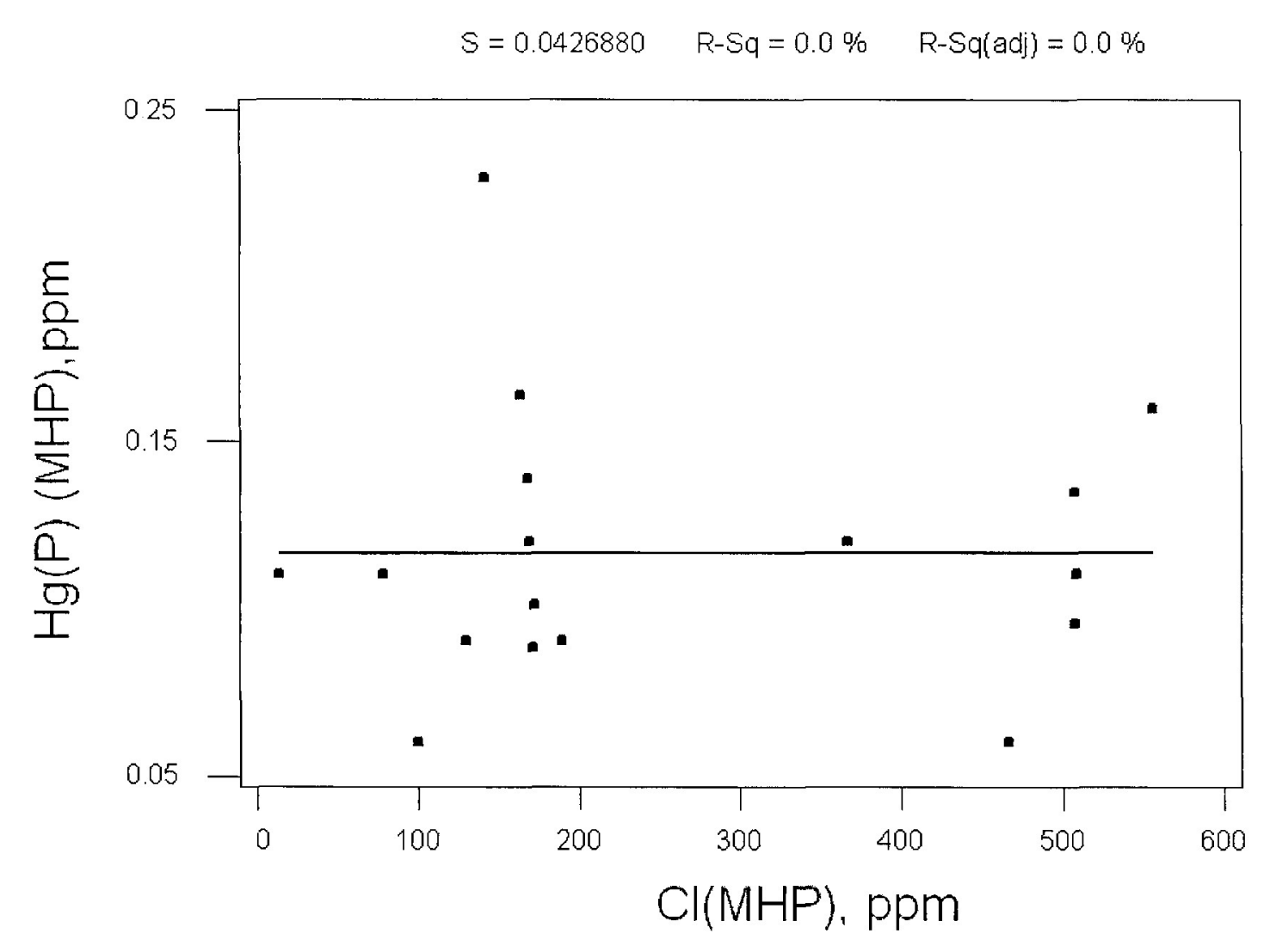

Figure 35. Regression plot of particulate mercury concentration vs. chlorine concentration in fly ash collected from the mechanical hopper. 


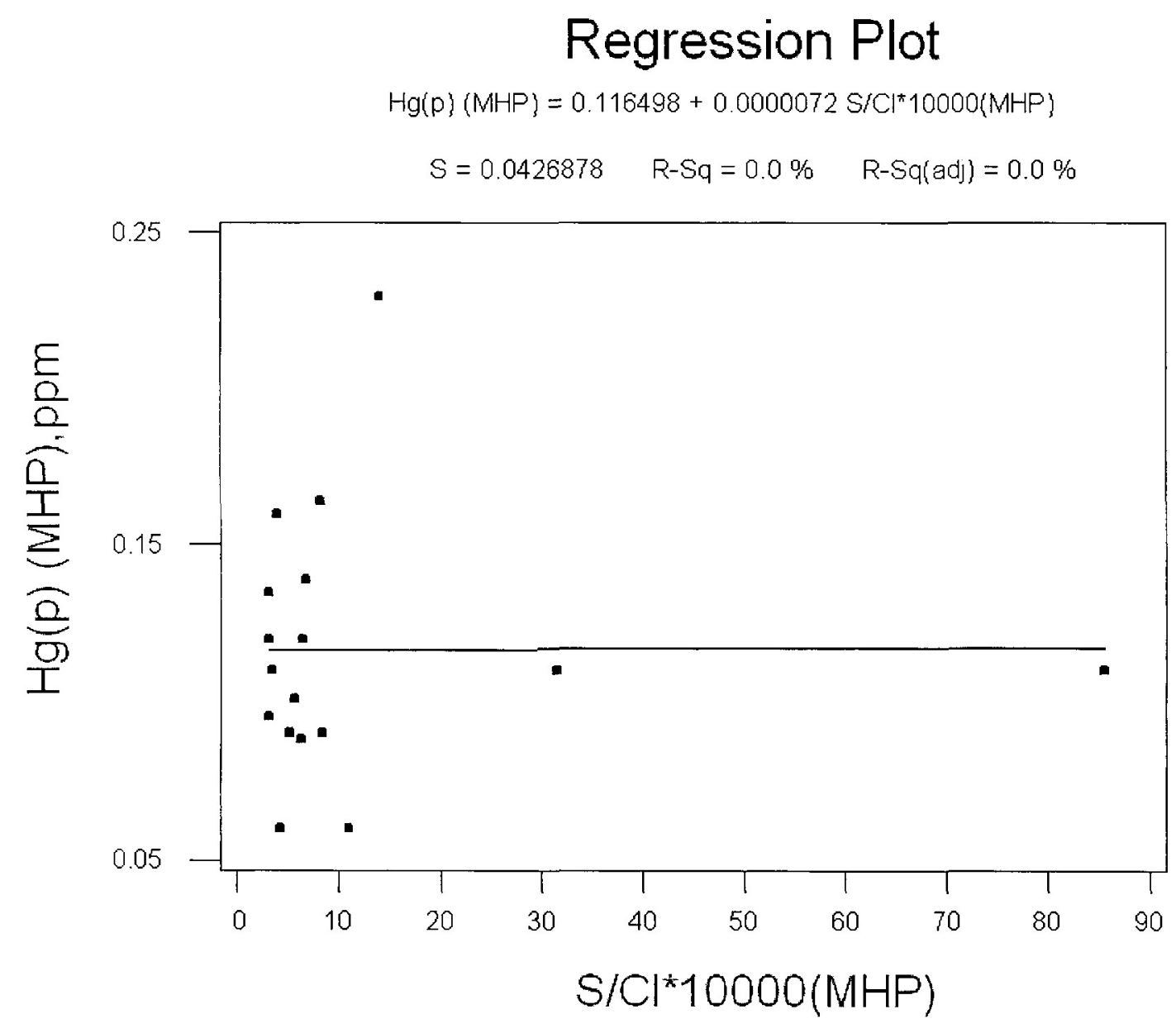

Figure 36. Regression plot of particulate mercury concentration vs. $\mathrm{S} / \mathrm{Cl} * 10^{4}$ in fly ash collected from the mechanical hopper. 


\section{Regression Plot}

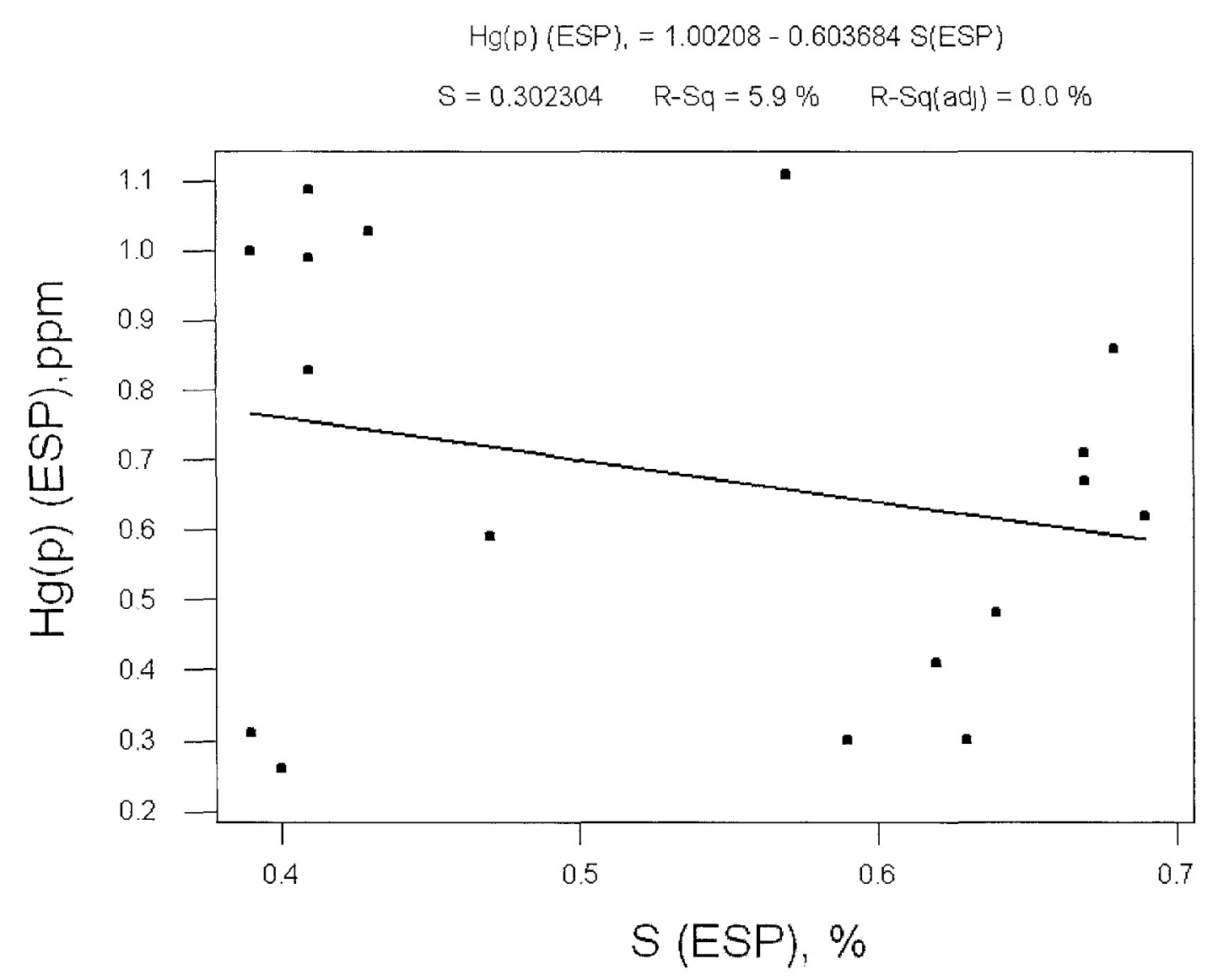

Figure 37. Regression plot of particulate mercury concentration vs. sulfur concentration in fly ash collected from the electrostatic precipitator. 


\section{Regression Plot}

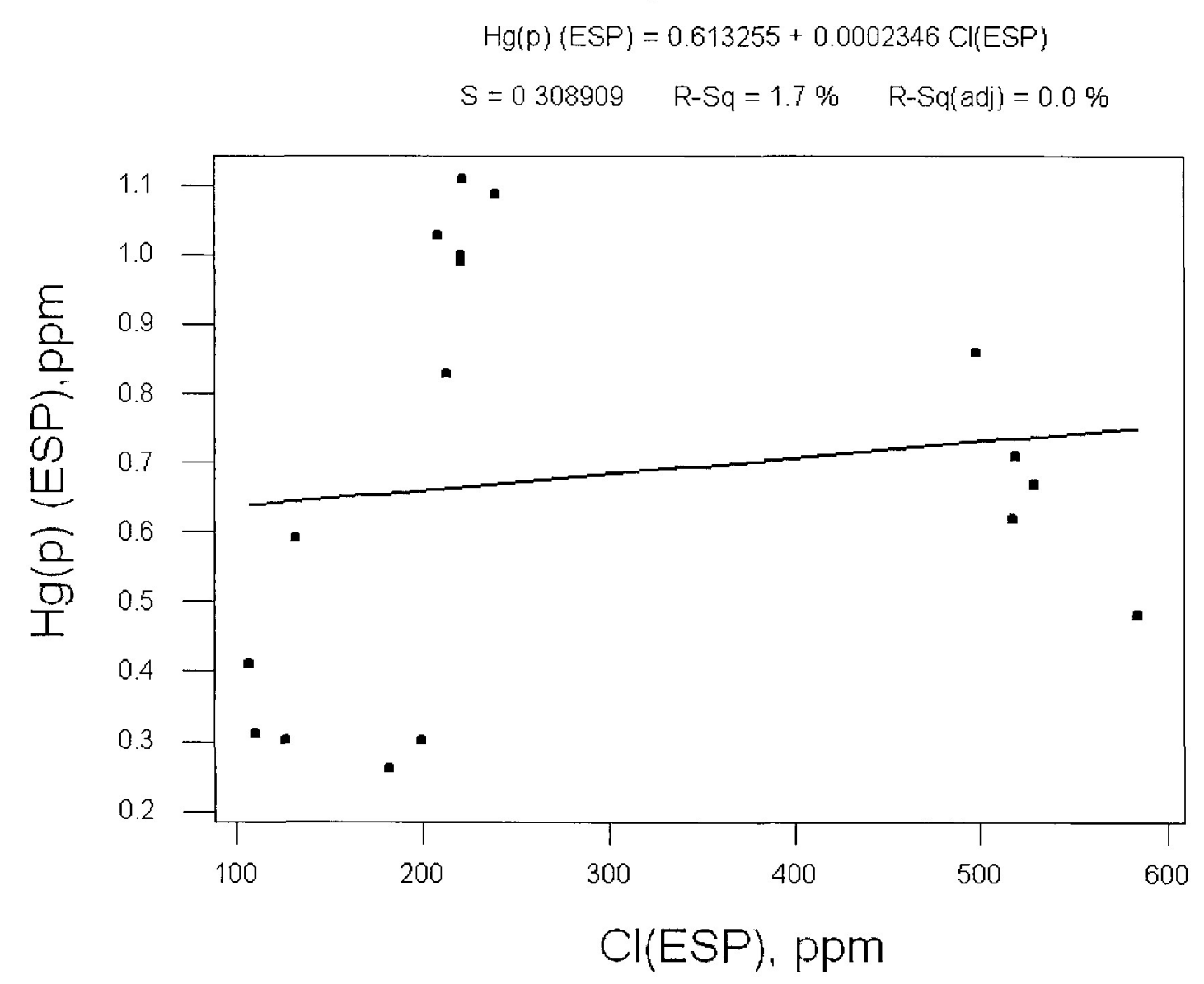

Figure 38. Regression plot of particulate mercury concentration vs. chlorine concentration in fly ash collected from the electrostatic precipitator. 


\section{Regression Plot}

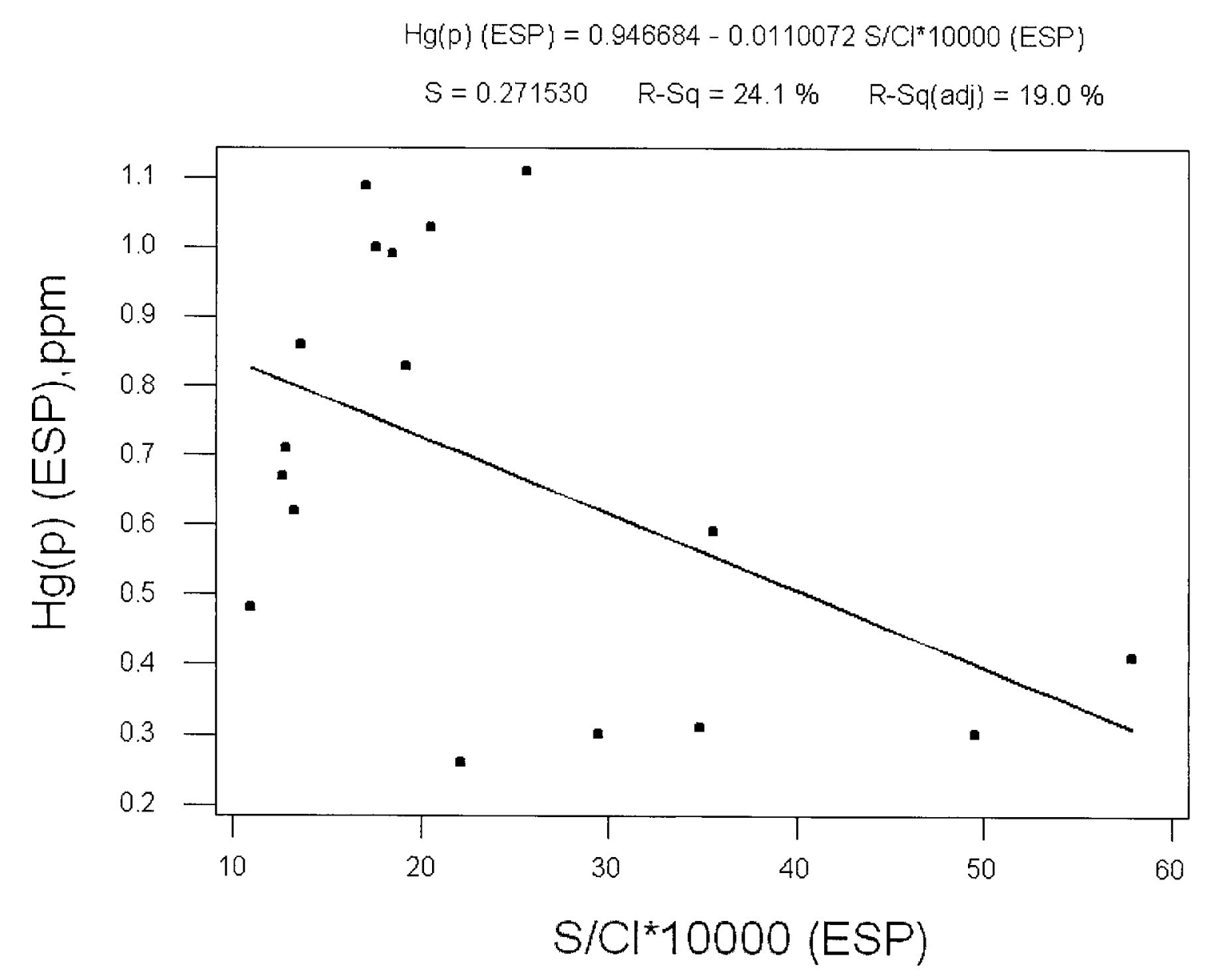

Figure 39. Regression plot of particulate mercury concentration vs. $\mathrm{S} / \mathrm{Cl} * 10^{4}$ in fly ash collected from the electrostatic precipitator. 
LOI are two important factors that will result in high concentrations of mercury in fly ash which results in more efficiently reduced mercury emissions. By comparing the two factors, particulate-bound mercury is more dependent on unburned carbon than is LOI. For the ESP fly ash, specific surface area shows a very important effect on mercury absorption, but there is very weak link between SSA and $\mathrm{Hg}^{\mathrm{p}}$ in the MHP fly ash. By removing the fly ash with large SSA and high $\mathrm{Hg}^{\mathrm{p}}$ from the ESP, the mercury emission can be controlled efficiently. 


\section{CONCLUSIONS}

Mercury emission from coal-fired power generating stations can be reduced with mercury bound in fly ash from the flue gas. The mercury concentration $\left(\mathrm{Hg}^{\mathrm{P}}\right)$ is varied and dependent on the properties of fly ash. The $\mathrm{Hg}^{\mathrm{P}}$ at the mechanical hopper is lower than that at the electrostatic precipitator where some fly ash will be removed with mercury before the flue gas flows into the stack.

LOI and unburned carbon have positive influences on mercury concentration in the particulate phase. With an increase in LOI and unburned carbon concentrations in fly ash both at the MHP and the ESP, the particulate phase mercury concentration tends to increase. The $\mathrm{Hg}^{\mathrm{P}}$-LOI-unburned carbon regression model indicates that $\mathrm{Hg}^{\mathrm{P}}$ is more dependent on unburned carbon than LOI. Some sorbents containing activated carbon will be an efficient method to capture mercury in fly ash and reduce mercury emission. The regression models can be described as follows:

$$
\begin{aligned}
& \mathrm{Hg}^{\mathrm{p}}(\mathrm{MHP}), \mathrm{ppm}=0.0230+0.00838 \text { Carbon }(\mathrm{MHP}), \%+0.00385 \mathrm{LOI}(\mathrm{MHP}), \% \\
& \mathrm{Hg}^{\mathrm{p}}(\mathrm{ESP}), \mathrm{ppm}=-0.0180+0.0670 \text { Carbon (ESP), } \%+0.0448 \text { LOI (ESP), } \%
\end{aligned}
$$

SSA, the specific physical property of fly ash, can affect the $\mathrm{Hg}^{\mathrm{P}}$ within a limited range. The SSA of fly ash at the ESP is larger than the MHP. SSA shows a very clear linear relationship with $\mathrm{Hg}^{\mathrm{P}}$ at the ESP, but very poor for the ash at the MHP. It was determined that very low mercury concentrations and small SSA will lead to deviation for the regression. The diameter of fly ash at the ESP is very small and produces large 
SSA; therefore, more mercury is bound in fly ash. This surface absorption combined with a chemical catalyzing effect will determine the amount of mercury held in ash particles.

For the major and minor metal oxides analyzed in this study, the regression results for $\mathrm{Al}_{2} \mathrm{O}_{3}, \mathrm{MnO}_{2}, \mathrm{SrO}, \mathrm{Na}_{2} \mathrm{O}, \mathrm{MgO}, \mathrm{SiO}_{2}, \mathrm{CaO}, \mathrm{K}_{2} \mathrm{O}, \mathrm{SO}_{3}, \mathrm{P}_{2} \mathrm{O}_{5}, \mathrm{BaO}, \mathrm{Fe}_{2} \mathrm{O}_{3}$, and $\mathrm{TiO}_{2}$ show a very poor relationship with $\mathrm{Hg}^{\mathrm{p}}$. The R-Square factors are very low; therefore, the regression model can not be satisfied. It can be concluded that the metal oxides, sulfur, and chlorine have no significant effect on mercury absorbed by fly ash.

With an increase in the unburned carbon content in fly ash, the majority of mercury in the flue gas can be absorbed into fly ash and subsequently removed by capturing the particulate matter. 


\section{BIBLIOGRAPHY}

1. U.S. Department of Energy, Energy Information Administration. U.S. Coal Reserves: 1997 Update. DOE/EIA-0529(97). Office of Coal, Nuclear, Electric and Alternate Fuels, Office of Integrated Analysis and Forecasting, Washington, DC, February 1999.

2. Thomas D. Brown. "Mercury Measurements and Its Control: What We know, Have Learned, and Need to Further Investigate," Journal of the Air and Waste Management Association, June 1999, 1-97

3. U.S. Environmental Protection Agency. Database of information collected in the Electric Utility Steam Generating Unit Mercury Emissions Information Collection Effort. OMB Control No. 2060-0396. Office of Air Quality Planning and Standards. Research Triangle Park, NC. April 2001.

3. National Research Council. Toxicological Effects of Methylmercury. Committee on the Toxicological Effects of Methylmercury Board on Environmental Studies and Toxicology, Commission on Life Sciences. National Academy Press, Washington, DC, 2000.

5. Mishima, Akio. Bitter Sea: The Human Cost of Minamata Disease. Kosei Publishing Co., Tokyo, Japan, 1992.

6. U.S. Environmental Protection Agency, Mercury Study Report to Congress, Volume I: Excessive Summary, Office of Air Quality Planning and Standards and Office of Research and Development, 1997, EPA-452/R-97-003.

7. Brown, Ellen, Office of Air and Radiation, US EPA, "Current Policy Developments Concerning Control of Mercury Air Emissions." Proceedings, International Conference on Air Quality: Mercury, Trace Elements, and Particulate Matter, Arlington, Virginia, 2002

8. Toole-O'Neil, B.; Tewalt, S.J.; Finkleman, R.B.; Akers, R. "Mercury Concentration in Coal--Unraveling the Puzzle." Fuel, 1999, 78(4), 47-54.

9. Nolan, S.; Redinger E.; Amrhein, T.; Kudlac, A. "Mercury Emissions Control in Wet FGD Systems." Proceedings, International Conference on Air Quality: Mercury, Trace Elements, and Particulate Matter, Arlington," VA, September 9-12, 2002. 
10. Liu, K.; Gao, Y.; Kellie, S.; Xie, W.; Pan, W.-P.; Riley, J.T. "A Study of Mercury Removal in FBC System Fired with High Chlorine Coals," Combustion Science and Technology, 2001, 164, 145-162.

11. Liu, K.; Gao, Y.; Riley, J.T.; Pan, W.-P.; Mehta, A.; Ho, K.; Smith, S. “An Investigation of Mercury Emission from FBC Systems Fired with High-Chlorine Coals," Energy \& Fuels, 2001, 15(5), 1173-1180

12. French, C.L., W.H. Maxwell, W.D. Peters, G.E. Rice, O.R. Bullock, A.B Vasu, R. Hetes, A. Colli, C. Nelson, and B.F. Lyons. Study of Hazardous Air Pollutant Emissions from Electric Utility Steam Generating Units -- Final Report to Congress, Volume 1. EPA-453/R-98-004a. Office of Air Quality Planning and Standards, Research Triangle Park, NC, February 1998.

12. Keating,M.H., K.R. Mahaffey, R. Schoeny, G.E. Rice, O.R. Bullock, R.B. Ambrose, Jr., J. Swartout, and J.W. Nichols. Mercury Study Report to Congress, Volume II. EPA-452/R-97-004b. Office of Air Quality Planning and Standards and Office of Research and Development, Research Triangle Park, NC, December 1997.

13. Lee, C.W., R.K. Srivastava, J.D. Kilgroe, and S.B. Ghorishi. "Effects of Iron Content in Coal Combustion Fly Ashes on Speciation of Mercury." Paper presented at the 94th Annual Meeting of the Air \& Waste Management Association, Paper \# 156, Orlando, FL. June 24 -28, 2001.

14. Ghorishi, S.B., C.W. Lee, and J.D. Kilgroe. "Mercury Speciation in Combustion Systems: Studies with Simulated Flue Gases and Model Fly Ashes." Paper presented at the 92nd Annual Meeting of Air \& Waste Management Association, St. Louis, MO. June 20-24, 1999.

15. Norton, G.A., H. Yang, R.C. Brown, D.L. Laudal, G.E. Dunham, J. Erjave, and J.M. Okoh. "Role of fly Ash on Mercury Chemistry in Simulated Flue Gas Streams." Paper presented at the 94th Annual Meeting of the Air \& Waste Management Association, Paper \# 164, Orlando, FL. June 24 -28, 2001.

16. Ryan, J.V. "Development and Evaluation of Mercury CEMS for Combustion Emissions Monitoring." Proceedings, 17th Annual Waste Testing and Quality Assurance Symposium, Arlington, VA. August 15, 2001.

17. EPA Standard Test Method for Elemental, Oxidized, Particle-Bound, and Total Mercury in Flue Gas Generated from Coal-Fired Stationary Sources (Ontario-Hydro Method), October 27, 1999.

18. Electric Power Research Institute. Evaluation of Flue Gas Mercury Speciation Methods, Final Report TR-108988, Palo Alto, CA, December 1997. 
19. Ryan, J.V. "Development and Evaluation of Mercury CEMS for Combustion Emissions Monitoring." Proceedings, 17th Annual Waste Testing and Quality Assurance Symposium, Arlington, VA. August 15, 2001.

20. U.S. Environmental Protection Agency. "Method 101A—Determination of Particulate and Gaseous Mercury Emissions from Stationary Sources." Code of Federal Regulations, Title 40, Part 61, Appendix B.

21. Smith, F. J., G.L. Shields, and C.J. Mahesh. "Reduction of Toxic Trace Elements in Coal By Advanced Cleaning." Presented at the Thirteenth Annual International Pittsburgh Coal Conference, September 3-7, 1996.

23. Buonicore, A.J., Davis, W.T. Air Pollution Engineering Manual. Air \& Waste Management Association, Van Nostrand Reinhold, New York, NY. 1992.

24. Woodward, K. Stationary Source Control Techniques Document for Fine Particulate Matter, EPA/425/R-97-001 (NTIS PB99-116493). Office of Air Quality Planning and Standards, Research Triangle Park, NC, October 1998.

25. Turner, J.H., and McKenna, J.D. Fabric Filter Baghouses I - Theory, Design, and Selection. ETS, Inc., Roanoke, VA, 1989.

26. Grover, C., J. Butz, S. Haythornthwaite, J. Smith, M. Fox, T. Hunt, R. Chang, T. Brown, E. Prestbo. "Mercury Measurements Across Particulate Collectors of PSCO Coal-fired Electric Utility Boilers," EPRI/DOE/EPA Mega-Symposium, Atlanta, GA. August 1999. 